Again, the ulceration apparently took a longer period to attain the chronic stage extant than the few weeks' residence of the Walrus in the Gardens would account for. Furthermore, the nature of the food given at the Gardens, and the care and regularity with which it was examined, make it unlikely that such swarms of Entozoa were derived from it and developed in so short a period.

Whether the Entozoa had been derived from the food given on board ship, or in what manner they had originally reached the stomach of the Walrus, are questions which I am quite unprepared to answer; and speculation leaves the matter quite as undecided.

Dr. Baird has furnished the subjoined description of this Ascaris, which proves to belong to a new species.

\title{
Ascaris bicolor, Baird.
}

Head naked; labia distinct, prominent, rounded, and of moderate size. Both anterior and posterior portions destitute of alæ or wings. Body of worm cylindrical, attenuated anteriorly, of a brownish colour, except at the anterior extremity, which is white; the posterior extremity is sometimes red. The surface of the body is beautifully and minutely but distinctly striated across ; as seen under the microscope (with a power of two-thirds of an inch), the striæ on each side terminate in such a manner that the edges of the body appear as if serrated. Caudal extremity thicker than anterior, obtuse, and generally convoluted.

A great many specimens were found in the stomach; but apparently all were females.

The Ascaris simplex of Rudolphi, found in the stomach of the Porpoise (Phocana communis), very nearly approaches this species in general appearance and size, but differs from it in several respects.

The Ascaris bicolor is less attenuated at the anterior extremity than the $A$. simplex, and is destitute of alæ or wings equally at the posterior and at the anterior extremity. The striations on the surface of the body are much finer, and the labia or valves at the mouth are more distinct and larger.

Length from $2 \frac{1}{2}$ to 3 inches; breadth from 2 to $2 \frac{1}{2}$ millimetres.

Hab. Stomach of a young male Walrus (Mus. Brit.).

February 13, 1868.

John Gould, Esq., F.R.S., V.P., in the Chair.

Mr. P. L. Sclater called attention to a Bear recently added to the Society's Menagerie, which appeared to be distinct from every recognized species. In general appearance it somewhat resembled the American Black Bear (Ursus americanus), but differed in its finer fur, larger and less densely clothed ears, pale brown muzzle, and white crescent-shaped mark on the chest, which was connected with 
the brown chin by an ill-defined brown line. The shape of the muzzle was also much sharper and more prolonged than in $U$. americanus, rendering the distance between the eye and the point of the nose comparatively greater, as was shown by sketches of the heads of these two animals.

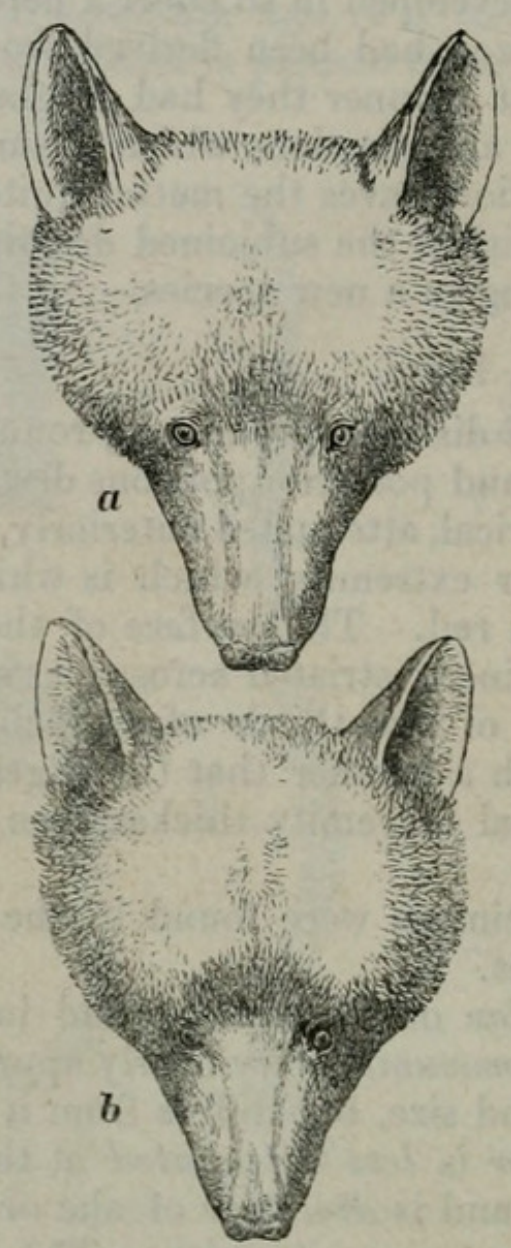

a. Ursus nasutus. b. Ursus americanus.

The specimen had been purchased of a dealer at Liverpool, and was stated to have been brought from the West Indies. It was probably from some part of the South-American Continent. The only generally recognized South-American Bear was the Spectacled Bear (U. ornatus), figured in Geoffroy St.-Hilaire and F. Cuvier's 'Hist. Nat.' (ii. t. 218), which was known by the brown spectacle-like markings on the forehead, and had a short broad nose. Tschudi had described a second species, from Peru*, which, however, did not seem at all to resemble the present animal. But it was very possible that the Venezuelan Bear, described by Sir R. Ker Porter, in a communication made to this Society on the 22nd of October, $1833+$, might refer to it, as the description and presumed locality alike agreed with it.

* Ursus frugilegus, Tsch. F. P. Mamm. p. 90, characterized as "supra nigro- fuscus concolor, subtus brunneus." Dr. Gray, in his lately published revision of the Ursida (P. Z.S. 1864), seems to have altogether overlooked this species.P. L. S.

† See P. Z. S. 1833 , p. 114. 



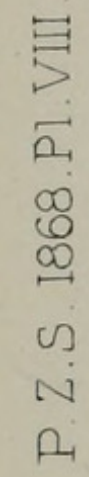

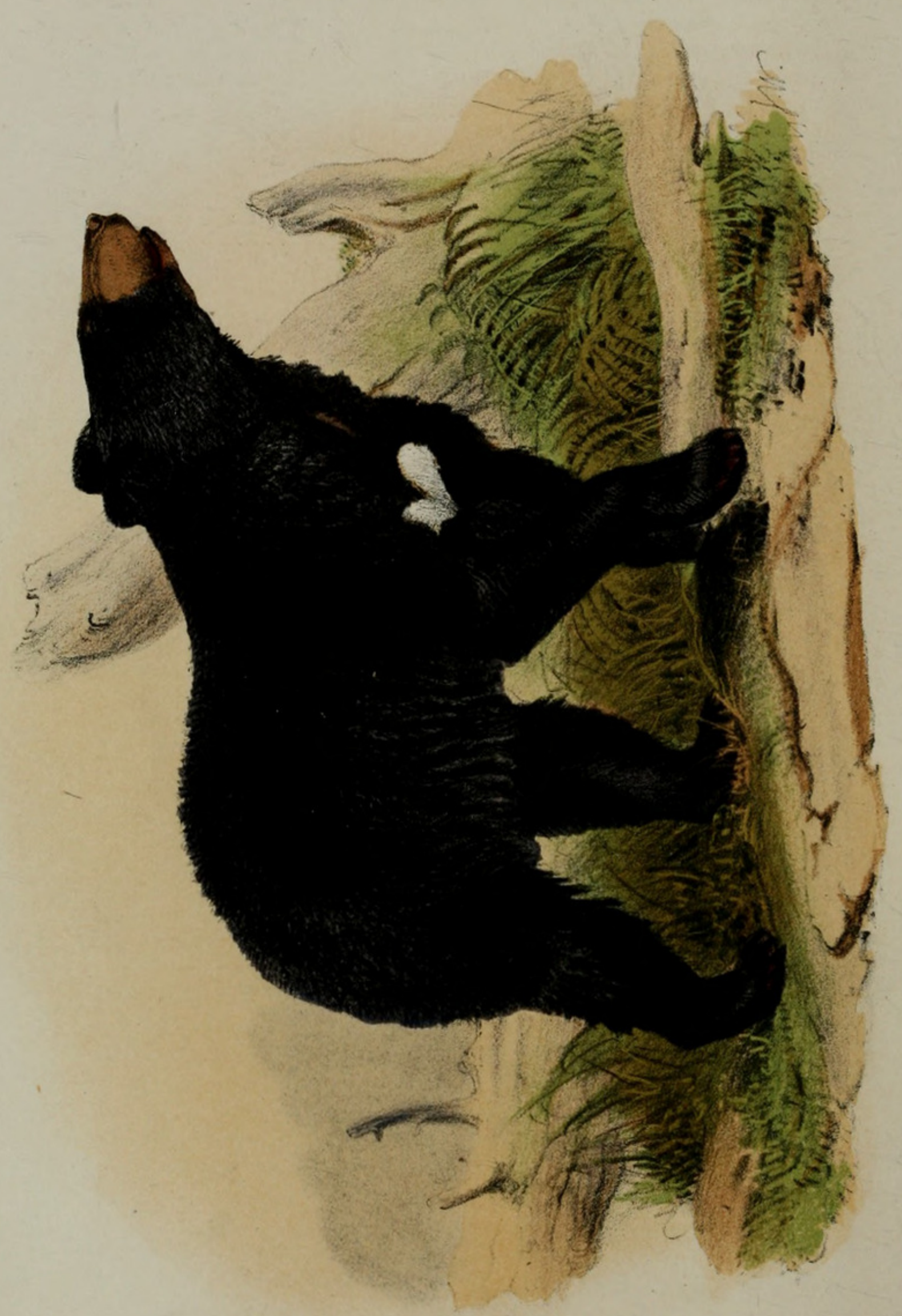

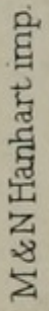


Mr. Sclater proposed the temporary name of Ursus nasutus for this Bear, until its characters could be more completely determined from an examination of its osseous structure, and exhibited a drawing of it by Mr. Wolf (Pl. VIII.).

In concluding his remarks, Mr. Sclater submitted the following list of the Society's living collection of species of the genus Ursus, which was stated to consist of nineteen individuals :1846.

1. Thalassarctos maritimus. Female, purchased September 28th,

2. Ursus arctos. Presented by Capt. W. Beauchamp Seymour, R.N., C.B., October 18, 1864 ; said to be from Japan.

3. U. arctos. Received in exchange, February 7, 1866.

4. U. syriacus. Female, purchased April 4, 1851.

5. U. syriacus. Male, presented by E. T. Rogers, Esq., H.B.M.'s Consul at Damascus, September 21, 1864; from Syria.

6. U. piscator. Presented by W. Scott Stonehewer, Esq., September 14, 1867 . See P.Z. S. 1867, p. 817.

7. U. piscator. Deposited, January 23, 1868.

8. U. tibetanus. Female, presented by W. H. Russell, Esq., F.Z.S., October 7, 1859 . From India.

9. U. tibetanus. Presented by H. O. Hebeler, Esq., 6th Regt. Foot, September 19, 1864. From India.

10. U. tibetanus. Presented by Robert Swinhoe, Esq., September 24, 1867. From Formosa. U. formosanus, Swinhoe. See P. Z. S. 1867 , p. 818 .

11, 12. U. japonicus. Two females, purchased April 1, 1863.

13. U. americanus. Presented by Capt. D'Arcy, R.N., November 22,1864 .

14. U. americanus. Deposited, March 1, 1866.

15. U. americanus. Presented by Capt. David Herd, H.B.C.S., C.M.Z.S., November 8, 1866 . From the Hudson's Bay Territory.

16. U. nasutus. Purchased, January 28, 1868.

17. U. malayanus. Purchased, March 12, 1863.

18. U. malayanus. Presented by T. Paudorf, Esq., September $14,1867$.

19. Melursus labiatus. Purchased, October 21, 1865.

Mr. Sclater exhibited a specimen of the egg of the Guacharo (Steatornis caripensis), which had been taken from one of the caves

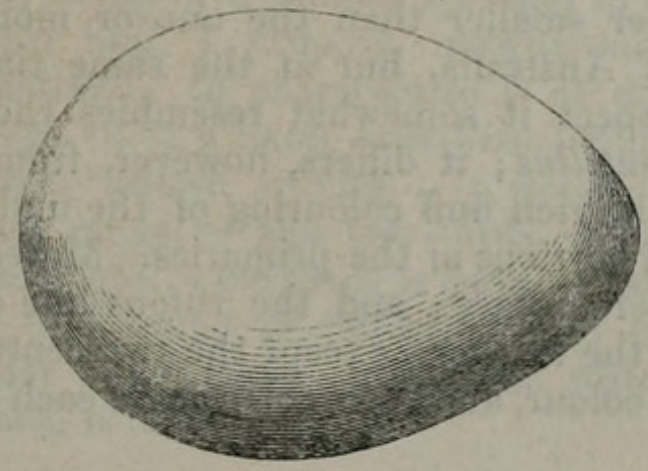


inhabited by this bird in the island of Trinidad, and presented to him by the Hon. Arthur Gordon, C.M.Z.S., Governor of the island.

The egg was elliptical in shape and pure white in colour, the larger axis measuring 1.7 inch, and the smaller $1 \cdot 2$.

The following papers were read :-

\section{On Two New Australian Birds. By Jонn Gould, Esq., F.R.S.}

One of the many results which attend the progress of colonization over the great country of Australia is the bringing to light of new species in every department of zoological and botanical science. Whether the explorer proceeds towards the centre of this vast region, or in the direction of the as yet but little-known northern coast, some new bird is sure to be brought under our notice; and thus, through the exertions of the earlier settlers and the zeal of public officers, Northern Queensland has yielded many fine species previously unknown, some of greater interest than others. That the supply from this quarter is not yet exhausted seems evident from the fact that we rarely examine a fresh collection thence without finding therein either a new species or a specimen in such a state of plumage as to induce an anxious desire to see an example of it in its full beauty. The next collection that arrives probably adds something to our knowledge of the subject; and a third furnishes us with all we desire respecting it. For some years past I have been treasuring up all the specimens I could obtain of the little Bronze Cuckoo of Cape York, under the impression that it would ultimately prove to be distinct from the species of the same form inhabiting New South Wales, Western Australia, and Tasmania; and I have now before me four, exhibiting a uniformity of characterization which distinguishes them from all their congeners, however closely allied. To the unpractised eye they would appear to be identical with one or other of the previously described species; and a cursory observer might suppose that the Australian members of this genus are identical with those inhabiting the islands to the northward of that country, This, however, I venture to say, is not the case, and I shall here point out in what particulars the bird from the Cape-York peninsula differs from the rest. In size it is rather smaller than the one or more inhabiting the southern coast of Australia, but at the same time has a stouter bill, in which respect it somewhat resembles the Port-Essington Chrysococcyx minutillus; it differs, however, from that and every other species in the rich buff colouring of the under surface of the wings or the basal portions of the primaries. Moreover a rufous tint pervades the upper surface; and the rufous hue of the tail is of a deeper colour, all the feathers, except the two central ones, being of a rich rusty fawn-colour, and the outer one on each side only marked 
with spots or bands of black and white; a similar mark of black and white also occurs on the tips of the three other lateral feathers. In some individuals (probably immature) the feathers of the scapularies are indistinctly barred near the shoulder with the bronzy green and buff seen in some of the extra-Australian species of the genus, but which I have not observed to exist in any other examples from that country. It would not have been necessary to give such minute details respecting this little Cuckoo, were it not most difficult to diagnose the members of this genus of parasitic birds, respecting which we have yet much to learn, particularly with regard to the colouring of their eggs, which are frequently totally different from each other and from those of the Maluri, Acanthiza, and other birds in whose nests they are deposited. The young, too, are most puzzling; for they do not appear to follow the law which obtains in the young of the true Cuckoos (genus Cuculus), and, instead of being strongly barred like them, they are coloured uniformly, the outer tail-feathers only being barred with black and white.

Not having the opportunity or sufficient materials at hand to clear up these points, I have requested Mr. Ramsay of New South Wales to investigate those of the southern coast; and he will doubtless be most accurate in his statement as to the period when the throat and under surface becomes barred. That this takes place very soon after the birds leave the nest appears to be certain; at least I have specimens now before me which justify such an opinion. Has not my friend Professor Schlegel described a little Cuckoo in this state? And if so, has he not been deceived by the unusual state of plumage?

The specific appellation I propose for the Cape York Chrysococcyx is russata, from the rusty hue of the under surface of the primaries.

Besides the Bronze Cuckoos, many of the birds of the Cape-York district differ from allied species inhabiting other parts of Australia ; I may instance the Maluri, the Meliphaga, \&c. There also we find a beautiful and apparently very common Pitta, closely assimilating in colour, but in colour alone, to the P. strepitans; and I seldom receive a letter from my ornithological friends in Australia in which inquiry is not made as to whether it has been named. By more than one have I been favoured with the opinion that it is distinct from its near ally; yet up to the present time no specific appellation has, I believe, been assigned to it.

Having lately had a great number of specimens forwarded to me which all agree in being of a smaller size and in having the under surface of a deeper buff, I propose, notwithstanding the opinion given in my 'Handbook,' to characterize it as distinct, and at the same time to assign to it a name (simillima) which shall mark its affinity to the older known species. It would be interesting to ascertain the exact range of the two birds, and at what part of Australia they inosculate. One thing is certain; no example of Pitta simillima has yet been found in the brushes of New South Wales, where, on the other hand, the P. strepitans, which has never been found at Cape York, is abundant. 


\section{Chrysococcyx russata, Gould.}

Head, all the upper surface, and wings pale shining rusty bronze; under surface white, crossed by numerous bands of bronzy brown; a wash of rufous across the breast, most apparent or defined on the sides in front of the shoulders; under wing-coverts barred like the breast ; base of the primaries and secondaries deep fawn-colour ; tail deep rufous, the two centre feathers glossed with bronze, the lateral feather on each side with three double spots, the upper half black, in the form of a crescent, the lower round and white, a similar spot on the tip of the inner web of each of the next three feathers on each side, but with the white greatly diminishing as they approach the centre; bill black; legs and feet olive.

Total length $5 \frac{3}{4}$ inches, bill $\frac{5}{8}$, wing $3 \frac{1}{2}$, tail $2 \frac{5}{8}$, tarsi $\frac{1}{2}$.

$H a b$. Cape-York district of Queensland, Australia.

\section{Pitta simillima, Gould.}

Crown deep ferruginous, with a narrow stripe of black down the centre; on the chin a large spot of black, terminating in a point on the front of the neck, uniting with a broad band on each side of the head, encircling the crown and terminating in a broad rounded point at the base of the neck; back and wings pure olive-green; shoulders and lesser wing-coverts bright metallic cerulean blue; across the rump a band of the same colour; upper tail-coverts and tail black, the latter tipped with dark olive-green; primaries black, becoming paler at the tip; near the base of the fourth, fifth, and sixth a small spot of white ; sides of the neck, throat, breast, and flanks buff; on the centre of the abdomen a patch of black; vent and under tail-coverts scarlet; irides dark brown; bill brown; feet flesh-colour.

Total length $7 \frac{1}{4}$ inches, bill $1 \frac{1}{8}$, wing $4 \frac{3}{8}$, tail $1 \frac{3}{4}$, tarsi $1 \frac{1}{2}$.

$H a b$. Cape-York district of Queensland, Australia.

2. Monograph of the Species of Worms belonging to the Subclass Gephyrea; with a Notice of such Species as are contained in the Collection of the British Museum. By W. BaIrd, M.D., F.R.S., F.L.S., \&c.

(Plates IX., X., XI.)

\section{Subclass GEPHYREA*.}

Gephyrea, Quatrefages, Ann. des Sciences Nat. 3rd ser. Zool. tom. vii. p. 340, 1847; Hist. Nat. des Annelés, Annélides et Géphyréens, tom. ii. pt. 2. p. 563, 1865 ; Ehlers in Zeitschrift für wissenschaft. Zool. Band xi. Heft 2. p. 205, 1861.

Rhyngodea, suborder Proctucha, tribe Sipunculidea, Diesing, Syst. 

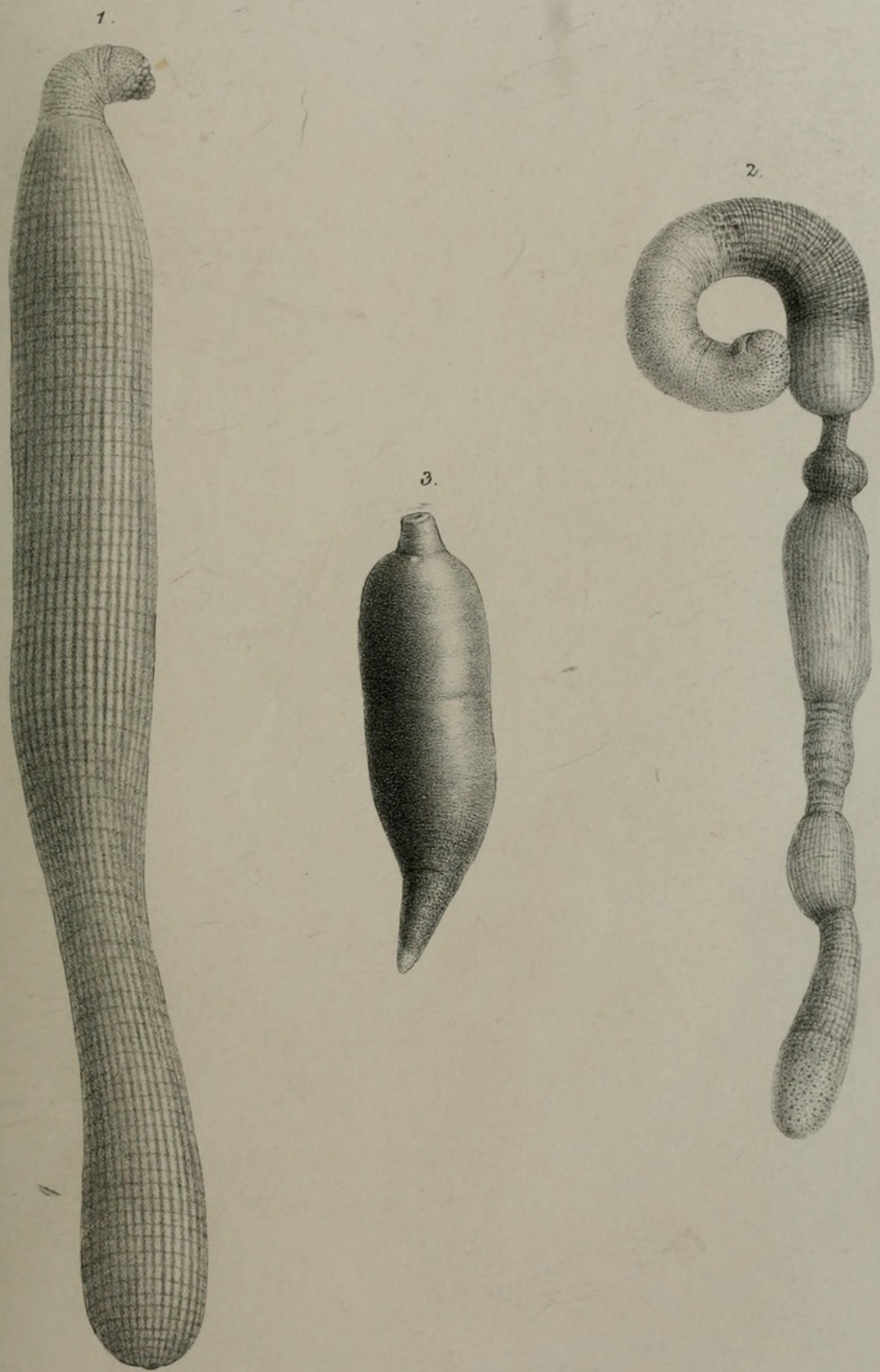

R. Minternlith,adnat

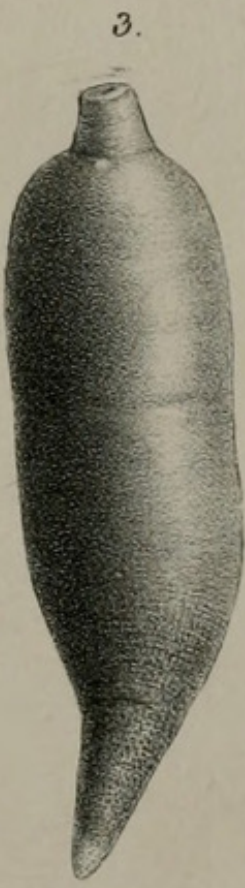

New species of Gephyrea. 


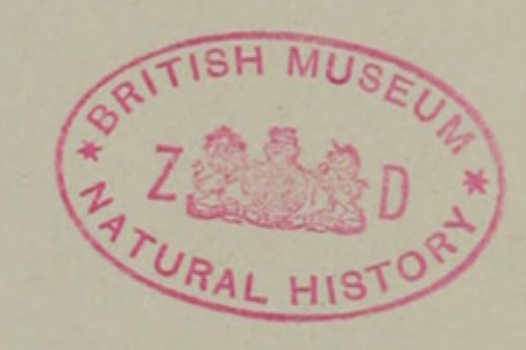


P.Z.S.1868.P1X.
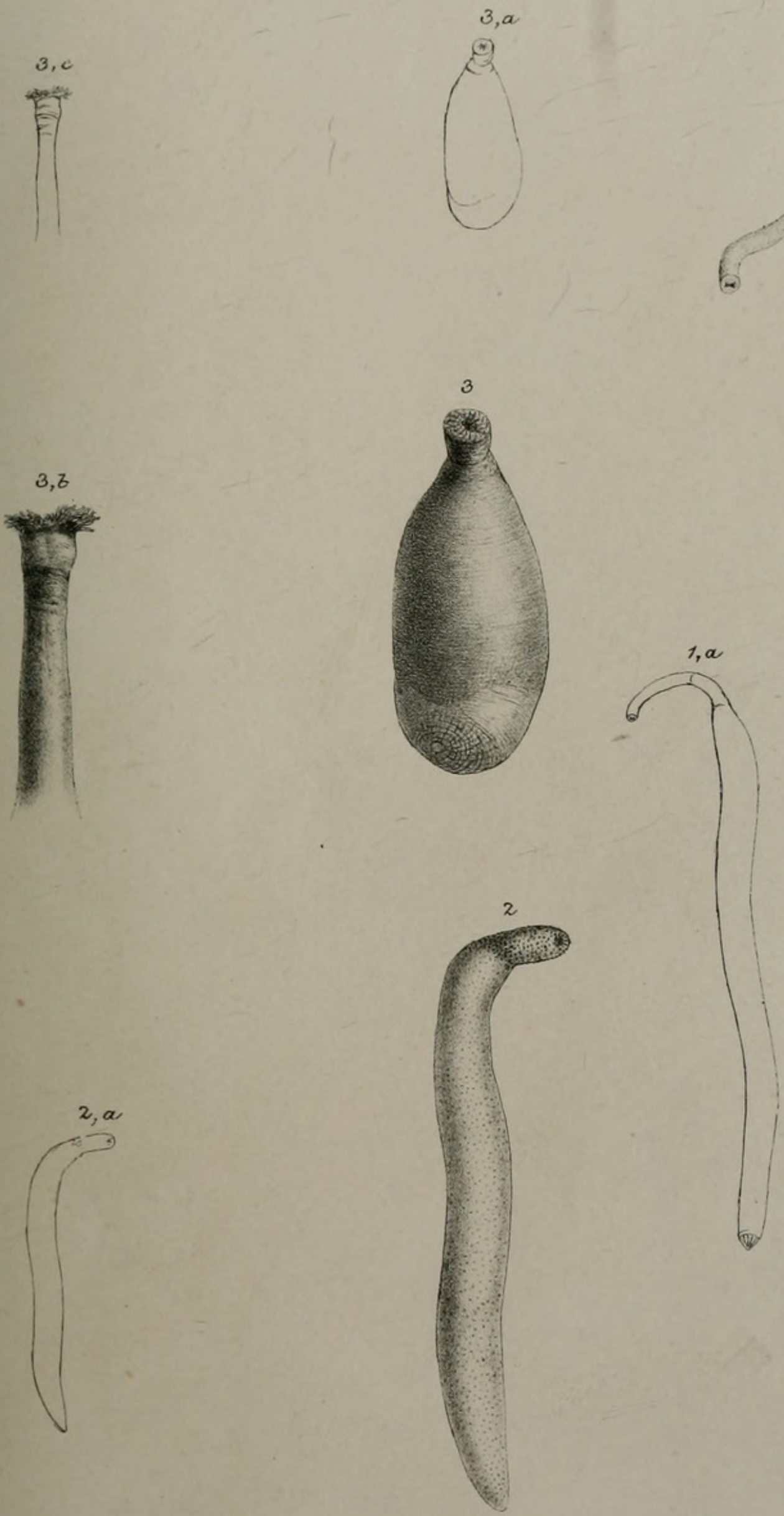

R.Mintern lith ad nat.

W.West imp

New species of Gephyrea. 
8 
P.Z.S.1868.PI XI.
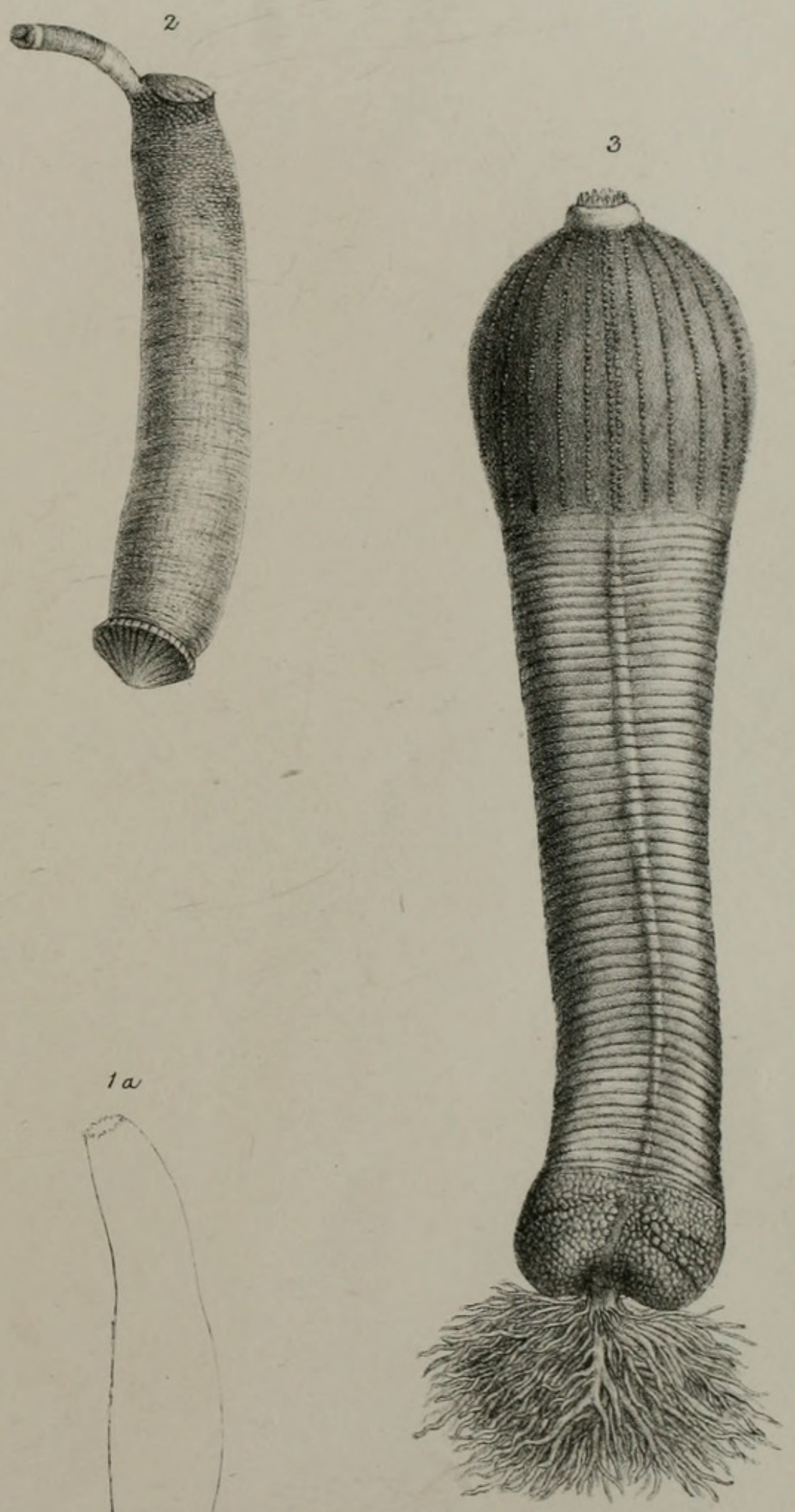

R Binternlith ad nai

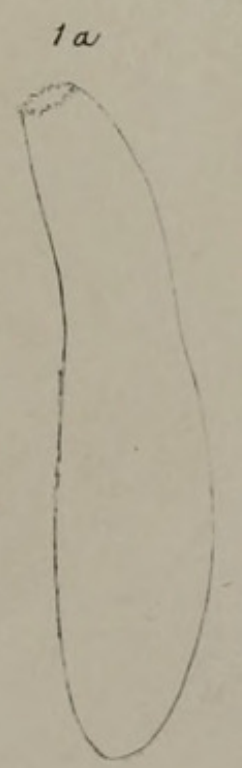

W. West inep.

New species of Gephyrea. 

Helminth. tom. ii. p. 59, 1851; Revis. der Rhyngod. in Sitzungsbericbte der kaiserlichen Akad. der Wissenschaft. Band xxxvii. p. 751 , 1859 .

\section{Order I. GEPHYREA INERMIA.}

Gephyrea inermia, Quatrefages.

Sipunculidea acrostomata, Diesing, Revis. der Rhyngod.

Sipunculida, Keferstein.

\section{Family I. Sipunculide.}

Sipunculea, Quatrefages, 1865.

Sipunculacea, Brandt, 1835 ; Keferstein, 1865.

Eusipunculidea, Exaspidosiphones, Diesing, Revis. der Rhyngod. 1859.

Anoteroprocta, Baseoprocta (pars), Diesing, Syst. Helminth. 1851.

\section{Genus 1. Sipunculus.}

Sipunculus, Linnæus, Blainville, Lamarck, Cuvier, Grube, Diesing, Quatrefages, Keferstein, \&c.

Syrinx, Bohadsch, Forbes (pars).

Lumbricus, sp., Pallas.

\section{Sipunculus nudus.}

Vermis microrhynchoteros, Rondeletius, Gesner DeVermib. Aquatilibus, liber iv. p. 1226. fig. superior, 1558.

Vermis macrorhynchoteros, Rond. Gesner $l$. c. fig. infer.*

Syrinx, Bohadsch, De quibusd. Animalib. Marinis, pp. 93-95, t. 7. f. $6,7,1761$.

Sipunculus nudus, Linnæus, Syst. Nat. 12th edit. p. 1078, 1766; Pennant, British Zoology, vol. iv. p. 31, t. 20. f. 10 (bad), 1777 ; Barbut, Genera Vermium, p. 16, t. 2. f. 3, 1783†; Gmelin, Linn. Syst. Nat. vi. p. 3094 (synon. Martin exclud.), 1789; Lamarck, Système des Anim. sans Vertèb. p. 352, 1801, Hist. Nat. An. s. Vertèb. 1st edit. iii. p. 78, 1816, 2nd edit. iii. p. 469, 1840 ; Turton, Brit. Fauna, p. 128, 1807 ; Schweigger, Handbuch der Naturg. p. 553, 1820; Martens, Fauna Veneta, in Reise nach Venedig, Theil ii. p. 523, 1824 ; Blainville, Dict. des Sc. Nat. art. Sipunculus, tom. xlix. p. 309, and art. Vers, lvii. p. 554, Atlas, t. 31.f. 1, 1 $a, 1827$; Leuckart, Brev. Animal. quorund. descriptiones, pp. 20, 2 l, t. 1.f. 3, 1828 ; Fleming, British Animals, p. 491, 1828; Costa, Faun. del

* The two worms figured by Gesner, in the work quoted above, appear to me, without doubt, to represent the same species, only in different states of preservation in spirits. I have equally little doubt that they are identical with the Syrinx figured by Bohadsch, and that the two species given by Linnæus in the 'Systema Naturæ,' S. nudus and S. saccatus, are only different states of the same species, as has been pointed out by Cuvier and others.

+ The figure of $S$. nudus given by Barbut in the work quoted above is very bad and does not well represent this species; but the description appended to it is very good. The figure given by him of the S. saccatus is copied from Bohadsch, and refers to this species. 
Regn. di Napoli, p. 4, t. 1. f. 9, 1832?; Grube, Müller's Archiv für Anat. 1837, p. 237, t. 10. f. 1; Krohn, Müll. Archiv, 1839, p. 348; Grube, Actin. Echinod. Würm. Adriat. p. 43, 1840 ; Diesing, Syst. Helminth. ii. p. 60, 1851 ; Revis. der Rhyngod, l. c. p. 756, 1859; Keferstein, Beitr. z. Anat. der Sipunculoid. in Nachricht. königl. Gesellsch. der Wissenschaft. zu Göttingen, p. 196, 1865; Zeitsch. für wisseuschaft. Zool. 1867, p. 45; Quatrefages, Hist. des Annelés, $l$. $c$. p. $614,1865$.

Sipunculus reticulatus, Martin, Observ. on Marine Vermes, \&c., p. 6 , t. 1. f. 3,1786 .

Syrinx tesselatus, Rafinesque, Précis des découvertes, p. 32, 1814.

Sipunculus tesselatus, Keferstein, l.c. p. 196, 1865.

Sipunculus balanophorus, Delle Chiaje, Mem. sull. Stor. e Notom. Animal. s. Vertebre, tom. i., sur la Notom. e la Classificaz. del Sipunc. Nud. p. 22 , t. I. f. $1-7,1823$.

Syrinx nudus, Forbes, Brit. Starfishes, p. 245. fig., 1841.

Sipunculus saccatus, Barbut (not Linn.), Genera of Worms, p. 18. t. 2. f. 4, 1783 (figure copied from Bohadsch); Turton, British Fauna, p. 128, 1807 .

$H a b$. Mediterranean; British seas; Weymouth and Devonshire (Mus. Brit.) ; ?American seas; (Keferstein).

B.M.

\section{Sipunculus phalloides.}

Lumbricus phalloides, Pallas, Spic. Zool. tom. i. fasc. 10. p. 12, t. 1. f. 8,$17 ; 4$.

Sipunculus phalloides, Blainville, Dict. Sc. Nat. art. Sipunculus, tom. xlix. p. 311, 1827, Atlas, t. 32. f. 1 (copied from Pallas); Diesing, Syst. Helminth. ii. p. 61,1851 ; Revis. der Rhyngod. $l$. c. p. 757, 1859; ?Grube, Annulat. Ersted. p. 12, 1858*; Keferstein, Beitr. z. Anat. der Sipunc. in Gesellsch. Wissensch. Götting. p. 196, 1865; Quatrefages, Hist. Nat. Annel. p. 615, 1865.

? Nereis (sacculo induta), Linnæus, Chinensia Lagerstrœmiana, f. 5, 1754 ; and in Amœn. Acad. iv. p. 254, t. 3. f. 5 (1788).

? Sipunculus saccatus, Linnæus, Syst. Nat. ed. 12, p. 1078, 1766†; Gmel. Syst. Nat. et var. $\beta$, p. 3095,1789 ; Bosc, Hist. Nat. des Vers, ii. p. 130, 1802; Turton, Brit. Fauna, p. 128, 1807 ; Lamarck, An. s. Vert. lst edit. iii. p. 79, 1816, 2nd edit. iii. p. 469, 1840 ; Fleming, Brit. Anim. p. 491, 1828.

Hab. Shores of Grenada (Pallas); Punta Arenas (Ersted); Indian seas? (saccatus) (Linnceus).

* Grube describes the tentacular membrane (as he calls the cirri round the mouth) of Dujardin as being " 6 -fariam laciniata, laciniis iterum incisis," which does not agree with Pallas's description of his Lumbricus phalloides, and which, indeed, would almost place this species in the genus Themiste of Gray (Dendrostomum of Grube). The habitat, Punta Arenas in Central America, is not, however, very widely apart from that given by Pallas, "Shore of the island of Grenada in the West Indies."

+ Pallas refers the saccatus of Linnæus, with a doubt, to his species L. phalloides, it only differing in the skin which covers it being rendered lax by having been badly preserved in spirits. 


\section{Sipunculus gigas.}

Sipunculus gigas, Quatrefages, Hist. Nat. Ann. ii. p. 514, 1865.

$H a b$. Coast of Brittany (Quatrefages).

I suspect this is only a variety of Sipunculus nudus. The chief difference seems to consist in the oral cirri, which, according to Quatrefages, are "quasi conglobati," or, as he elsewhere describes them, something like cauliflowers. This, however, he says may be the action of the spirits in which the specimen has been preserved.

\section{Sipunculus edulis.}

Lumbricus edulis, Pallas, Spic. Zool. tom. i. fasc. x. p. 11, t. 1 . f. 7,1774 .

Sipunculus edulis, Lamarck, An. s. Vert. 1st edit. iii. p. 79, 1816 ; 2nd edit.iii. p. 469, 1840; Blainville, Dict. Sc. Nat. art. Sipunculus, 1827, Atlas, t. 31. f. 4 ; Cuvier, Règn.Anim.iii. p. 243, 1830 ; Guérin Icon. Règn. An. Zooph. p. 8, pl. 5. f. 3 (copied from Pallas?); Griffith, An. Kingd. xii. Zooph. t. 12. f. 3 (copied from Guérin), 1834 ; Diesing, Syst. Helminth. ii. p. 61, 1851, Revis. der Rhyngod. l. c. 757, 185!); Quatrefages, Hist. Nat. Annel. ii. p. 615, 1865 .

Hab. Java (Pallas); Siam (Mouhot).

B.M.

\section{Sipunculus indicus.}

Sipunculus indicus, Peters, Müller's Archiv für Anat. \&c. 1850, p. 385 , t. 4. f. A-H* ; Diesing, Syst. Helminth. ii. p. 555, 1851, Revis. der Rhyngod. in l. c. p. 757, 1859 ; Keferstein, Beitr. z. Anat. der Sipunc. in l. c. p. 196, 1865 ; Quatrefages, Hist. Nat. Annel. ii. p. 615,1865 .

Hab. Coast of Mozambique (Peters).

\section{Sipunculus Rufofimbriatus.}

Sipunculus rufofimbriatus, Blanchard, Ann. Sc. Nat. 3rd ser. tom. xii. p. 56, 1849; Cuv. Règn. An. edit. Crochard, Zoophytes, t. 22. f. 1, $1 a$; Diesing, Syst. Helminth.ii. p.62, 1851 ; Revis.der Rhyngod. l. c. p. 757,1859 ; Quatrefages, Hist. Nat. Annel. ii. p. 616, 1865. Hab. Nice (Blanchard).

\section{Sipunculus echinorhynchus.}

Siphunculus echinorhynchus, Delle Chiaje, Memor. sulla Storia e Notom. degli Animal, s. Vertebre, tom. i. pp. $124 \&$ 133, 134, t. 10. f. $8-11,1823$.

Sipunculus echinorhynchus, Diesing, Syst. Helminth.ii. p. 60, 1851 ; Dujardin, in Lamk. An. s. Vert. 2nd edit. tom. iii. p. 469 ; Quatrefages, Hist. Nat. Annel. ii. p. 616, $1865 \uparrow$.

* Peters's figure of this species represents the tentacular membrane as being divided into a considerable number (eight according to Diesing) of lacinix or oral cirri, which appear again to be divided into others, amounting, according to Diesing, to from 40 to 60 . This structure would appear to be almost sufficient to refer this species to another genus, allied to the Dendrostomum of Grube.

+ Quatrefages says it is likely that this species may turn out to be only the young of $S$. nudus. The oral cirri, however, are very different from those of that species. 
Phascolosomum echinorhynchus, Diesing, Revis. der Rhyngod. l.c. p. $763,1859$.

Hab. Bay of Naples (Chiaje).

\section{Sipunculus robustus.}

Sipunculus robustus, Keferstein, Beitr. z. Anat. der Sipunc. in Nach. könig. Gesellsch. der Wissensch. Götting. p. 196, 1865 ; Quatrefages, Hist. Nat. Annel. ii. p. 616, 1865.

$H a b$. Wallis Islands, Oceania (Dr. Gräffe fide Keferstein).

\section{Sipunculus angasit, sp. nov. (Pl. IX. fig. 1.)}

Corpus cylindricum, incequale, infra medium contractum, laxe clathratum, longitudinaliter costatum et transverse striatum; apice caudali globoso-clavato, lavi; proboscis brevis, crassiuscula, cylindrica, muricata, oris limbo papilloso; totum corpus iridescens.

Long. corporis 6 unc., crassitud. in medio corporis 8 lin., long. proboscid. muricat. 8 lin.

Retractile portion of body, containing the proboscis, short, tolerably well developed, covered with numerous rather large triangular tubercles, the points projecting downwards. The tentacular membrane is divided in the centre into numerous short and somewhat conical papillæ, forming, as it were, a pad at the extremity of the proboscis. Body contracted a little below the middle. The upper portion is much the larger, and for a short distance below the proboscis it is divided, for about half an inch, by several rather deep circular sulci. Then the grooves or ridges run longitudinally throughout the whole length of the body, which is cylindrical, and terminates at the lower extremity in a round-shaped club, smooth and shining. The grooves or ridges in the upper half of the body are rather distant from each other, and are crossed by faint transparent circular lines. Below the contraction the circular grooves are more decided, and the longitudinal grooves are crowded and of a wavy form. The whole body is shining, and of an opal iridescent hue, especially about the centre of the body.

Hab. Port Lincoln, South Australia (G. F. Angas, Esq.). B.M.

\section{Sipunculus deformis, sp. nov. (Pl. IX. fig. 2.)}

Corpus subcylindricum, incequale, hinc et illinc valde constrictum, dense clathratum et tuberculatum, apice caudali subinflato, ovali, tuberculis parvis muricato; proboscis crassa, quintam partem longitudinis corporis aquans, tuberculis minimis rufis circulariter obsita; color corporis fuscus.

Longit. $5 \frac{1}{2}$ unc., crassitud. major 4 lin. ; long. probosc. $1 \frac{1}{2}$ unc., crass. prope extremitat. 3 lin.

Rectractile part of body, containing the proboscis, of considerable length, nearly equalling the fifth part of the body, roughened with numerous rery small brown dots or tubercles arranged in circular rows, robust, of nearly equal thickness with the rest of the body, ex- 
cept at the thickest portion. The extremity of the proboscis, containing the tentacular filaments, in the only specimen we possess, is withdrawn completely, so that it cannot be seen. The body is of a subcylindrical form, and is roughly clathrate, the longitudinal ridges being close set, and the circular striæ cutting rather deep, and forming, as it were, small tubercles along the longitudinal ridges, which are especially prominent near the base of the proboscis. In several places it is very much constricted, the constricted parts in one or two places being very narrow*. The caudal extremity is of an oval slightly inflated form, and densely roughened with crowded small tubercles. The general colour of the body is brown, the small dots or tubercles on the proboscis being of a deeper hue.

Hab. Sir Charles Hardy's Island, North Australia (J. B. Brookes, Esq.).

B.M.

11. Sipunculus eneus, sp. nov.

Corpus cylindricum, gracile, antice attenuatum, postice crassius, fusiforme, reticulatum, in parte anteriore corrugatum, deinde lavius et minute granulatum, apice caudali ovali, lavi, lucente; proboscis brevis, lavis, parte anteriore corporis crassior; color albus, eneo lucens.

Longit. corporis $6 \frac{1}{2}$ unc.; crass.part. anter. $1 \frac{1}{2}$ lin., part. posterior. 4 lin.; long. probos. 6 lin., crass. 2 lin.

The proboscis in this species is much thicker than the upper or anterior part of the body; so that it is difficult to imagine how the animal could withdraw it within its body, and "where it could pack it," as Professor Forbes says of another species. It is smooth-looking, but when examined with a glass we see it ringed or aunulated and finely reticulated. The oral cirri or tentacles are not visible in the only specimen we possess. The body is slender, ringed, the rings or annulations being very close together, small, and finely but distinctly reticulated across. The upper extremity is strungly corrugately reticulate, the middle portion less distinctly so, and the caudal almost smooth. Scattered over the surface we see a good many small warty-looking tubereles. The upper extremity is narrow, the body gradually enlarging in size as it descends, so that at the caudal extremity it is three times as large as anteriorly, and is of a fusiform conoidal form, the warty tubercles at the same time being larger there than elsewhere.

The general colour is nearly white, except towards the caudal extremity, where it is very shiny with an iridescent metallic lustre.

$H a b$. New Zealand ( $M r$. Cuming's Collection).

B.M.

12. Sipunculus eximio-clathratus, sp. nov.

Corpus cylindricum, infra medium courctatum dense clathratum, extremitatibus inflatis, laviusculis, iridescentibus; proboscis brevis, crassiuscula, muricata; color griseus.

Long. $2 \frac{1}{2}$ unc.; crassit. in medio 3 lin., ad extremitates $5 \frac{1}{2}$ lin.

* This may, to a considerable extent, be produced by the spirit in which the animal has been immersed.

Proc. Zool. Soc.-1868, No. VI. 
The body of the animal is cylindrical in form, rather narrow in the middle, and densely clathrate, presenting the appearance, to a certain extent, of chain armour. The two extremities are inflated and nearly smooth and shining, the longitudinal ridges being much wider asunder, and the transverse sulci shallow and less apparent; the posterior extremity is a little larger than the anterior. The proboscis is only partially excluded, but appears short and cylindrical, and is densely covered with triangular soft murications, the points projecting downwards. The body is of a grey colour, and the two extremities are somewhat iridescent.

Hab. Philippine Islands (Mr. Cuming's Collection). B.M.

\section{Sipunculus corallicolus.}

Sipunculus corallicolus, Pourtalès, Proc. Amer. Soc. Adv. Knowl. 1851, p. 41.

Hab. Florida, living in hollows in dead coral (Pourtales).

Another species has been shortly described; but, according to Diesing, it requires further investigation.

\section{Genus 2. Phascolosoma.}

Phascolosoma, Leuckart, Grube, Ersted, O. Schmidt, Keferstein, Costa.

Phascolosomum, Diesing.

Sipunculus (Phascolosomum), Quatrefages, l. $c$.

Sipunculus, Blainville, Forbes (in part), Grube (in part).

Siphunculus, Montagu, Gray.

Syrinx (part.), Forbes, M'Coy.

Phymosomum (part.), Quatrefages, $l$. c.

Edematosomum (part.), Quatrefages, $l$. c.

Cryptosomum (part.), Quatrefages, $l . c$.

$$
\text { * Species with the skin smooth. }
$$

\section{(Phascolosomum, Quatrefages.)}

\section{Phascolosoma harveit $\dagger$.}

Syrinx harveii, Forbes, British Starfishes, p. 249. fig., 1841; Gosse, Rambles of a Naturalist on the Devonshire Coast, p. 157, 1853.

? Sipunculus nudus, Bosc, Hist. Nat. des Vers, ii. p. 130, 1802 (Syn. Bohadsch exclud.); ? Turton, Brit. Faun. p. 128, 1807.

Siphunculus nudus, Martin, Marine Vermes, p. 4, t. 1. f. 2, 1786; Gray, Spic. Zoolog. p. 8, 1828.

Phascolosomum harveyi, Diesing, Revis. der Rhyngod.l.c.p. 763, 1859.

† In this species the extremity of the proboscis is encircled by a close-set series of short bristles, "as if," says Mr. Gosse, "it had omitted to shave its beard the day before;" and the oral cirri consist of a "dense tuft of white tentacula." 
Sipunculus (Phascolosomum) harveyi, Quatrefages, Hist. Nat. Annel. ii. p. 617,1865 .

Hab. Coast of England, Weymouth, Devonshire, Cornwall, \&e.

2. Phascolosoma forbesi*.

Syrinx forbesii, M'Coy, Ann. \& Mag. Nat. Hist. xv. p. 273, t. 16. f. 3,1845 .

Phascolosomum forbesi, Diesing, Syst. Helminth. ii. p. 66, 1851 ; Revis. der Rhyngod. l. c. 764, 1859.

Sipunculus (Phascolesomum) forbesii, Quatrefages, Hist. Nat. Ann. ii. p. 618, 1865.

Hab. South Devon, Cornwall (Montagu, Laughrin). B.M.

3. Phascolosoma tenuicinctum.

Syrinx tenuicinctus, $\mathrm{M}^{\circ} \mathrm{Coy}$, Ann. \& Mag. Nat. Hist. xv. p. 273, t. 16. f. $4,1845$.

Phascolosomum tenuicinctum, Diesing, Syst. Helminth. ii. p. 64, 1851 ; Revis. der Rhyngod. l. c. p. 764, 1859.

Sipunculus (Phascolosomum) tenuicinctus, Quatrefages, Hist. Nat. Ann. ii. p. 618, 1865.

$H a b$. Falmouth (J. Cranch).

B.M.

\section{Phascolosoma oxyurum.}

Lumbricus oxyurus, Pallas, Spic. Zoolog. i. fasc. 10. p. 16, 1774; Miscell. Zool. p. 147, t. 11. f. 7, 8, 1766 .

Sipunculus oxyurus, Blainville, Dict. Sc. Nat. xlix. art. Siponcle, p. 312, 1828.

Sipunculus, sp., Forbes, Brit. Starfishes, p. 255, 1841.

Anoplosomatum pallasii, Diesing, Syst. Helminth. ii. p. 69, 1851 ; Revis. der Rhyngod. l. c. p. 756, 1859; Quatrefages, Hist. Nat. Annel. ii. p. $631,1865 \uparrow$.

Hab. Hastings; coast of Sussex (Pallas).

B.M.

5. Phascolosoma capsiforme, sp. nov. (Pl. IX. fig. 3.)

Corpus cylindrico-fusiforme, lavissimum, lutescens, in medio inflatum, sacciforme, capsico simile, apice caudali acuminato, granuloso; proboscis cylindrica, crassiuscula, cirris brevibus, numerosis, apice clavatis, obsita.

Long. corporis 2 unc., crass. corporis in medio 10 lin., crass. apic. caudal. $2 \frac{1}{2}$ lin.

In this species the body is cylindrical and fusiform, very smooth-

* In this species the extremity of the proboscis is surrounded by from six to eight distinct circles of minute bristles, and the oral cirri are in the form of short laciniæ.

† One of the characters of the genus Anoplosomatum, according to its founder, Grube, and Diesing himself, is the position of the anus in the caudal extremity. Pallas, however, distinctly states that in this species the anus is placed in the anterior portion of the body; and the specimen we possess from the coast of Sussex, and which I refer to the oxyurus of Pallas, agrees in this particular with the description given by that author. 
looking and shining. It is inflated like a bottle, more swollen near the anterior extremity, but with the inferior extremity elongately acuminate and somewhat granular or warty. The general appearance of the animal, especialiy with the proboscis retracted, is that of a capsicum. The proboscis is thick and cylindrical, and at the apex is crowned with numerous short, fleshy-looking cirri, each slightly club-shaped at the free extremity. The surface of the body, when examined with the lens, presents the appearance of very minute circular striæ, and numerous, very fine, flat granulations. The posterior extremity becomes suddenly acuminated, and is of considerable length.

$H a b$. Falkland Islands ( $W$. Wright, Esq.).

B.M.

The $P$. capsiforme approaches in characters to the Sipunc. (Edematosomum) rapa of Quatrefages, a species brought by M. d'Orbigny, but from what quarter of the world the author does not state; neither has the proboscis been seen by M. Quatrefages, and the body is described as "albo setaceum," or like the cocoon of a white moth.

\section{Phascolosoma boreale.}

Phascolosoma boreale, Keferstein, Beitr. z. Anatom. der Sipunc. in l.c. p. 206, 1865. 1865 .

Sipunculus (Phascolosomum) borealis, Quatrefages, l.c. ii. p. 620,

Hab. Godthaab, Greenland, in from 30 to 40 fath. (Holbüll).

7. Phascolosoma cerstedit.

B.M.

Phascolosoma œerstedii, Keferstein, l. c. p. 205, 1865.

Hab. Godthaab, Greenland (Holböll).

Sipunculus (Phascolosoma) œrstedii, Quatrefages, l. c. ii. p. 620,

B.M.

8. Phascolosoma obscurum.

Sipunculus (Phascolosomum) obscurus, Quatrefages, l.c. ii. p. 616 , 1865 .

Hab. Les côtes de l'Océan (Quatrefages).

9. Phascolosoma vulgare.

Sipunculus vulgaris, Blainville, Dict. Sc. Nat. art. Siponcle, Atlas, pl. 33. f. 3, $3 a, b, 1828$.

Phascolosomum vulgare, Diesing, Syst. Helm. ii. p. 65, 1851; Revis. der Rhyngod. p. 759, 1859.

Phascolosoma vulgare, Keferstein, Beitr. in l. c. p. 201, 1865.

Sipunculus (Phascolosomum) vulgaris, Quatrefages, l. c. ii. p. 616, 1865 .

Hab. Dieppe (Blainville).

10. Phascolosoma punctatissimum.

Sipunculus punctatissimus, Gosse, Ann. \& Mag. of Nat. Hist. 2nd ser. vol. xii. p. 125, 1853; Quatrefages, l. c. ii. p. 617, 1865. 
Phascolosomum punctatissimum, Diesing, Rev. der Rhyng. $l$. $c$. p. 763,1859 .

Hab. English coast (Gosse); Isles of Chausey (Quatrefages).

\section{Phascolosoma rubens.}

Phascolosoma rubens, Costa, Faun. del Regn. di Nap. p. 11, t. 1. f. $6-8,1860$ ?

Phascolosomum rubens, Diesing, Rev. der Rhyng. l. c. p. 764, 1859 . Sipunculus (Phascolosomum) rubens, Quatrefages, $l$. c. ii. p. 617, 186.5

Hab. Coasts of Naples and Sicily (Costa).

\section{Phascolosoma carneum.}

Phascolosoma carneum, Leuckart \& Rüppell, Atlas der Reise im nördl. Africa, t. 2. f. 2, 1828 ; Diesing, Rev. der Rhyngod. in $l . c$. p. 764 .

Sipunculus carneus, Diesing, Syst. Helm. ii. p. 63, 1859.

Sipunculus (Phascolosomum) carneus, Quatrefages, l.c. ii. p. 618, 1865 .

Hab. Red Sea (Rüppell).

\section{Phascolosoma gouldir.}

Sipunculus gouldii, Pourtalès, Proc. Amer. Ass. for Advance. of Science, 1851, pp. 40, 41.

Phascolosomum gouldii, Diesing, Revis. der Rhyngod. in $l$. $c$. p. $764,1859$. 1865 .

Sipunculus (Phascolosomum) gouldii, Quatrefages, l.c. ii. p. 618,

Phascolosoma gouldii, Keferstein, Beitr. in Nach. Gesellsch. Wissen. Göttingen, p. 205, 1865 ; Zeitsch. fïr wissensch. Zool. Band xv. t. 33. f. 32, 1865, and Band xvii. Heft 1. p. 54, 1867.

Hab. Massachusets (Pourtalès).

\section{Phascolosoma violaceum.}

Sipunculus (Phascolosomum) violaceus, Quatrefages, Hist. Nat. des Annelés, ii. p. 619, 1865 .

Hab. Indian Seas (Quatrefages).

15. Phascolosoma vermiculum.

Sipunculus (Phascolosomum) vermiculus, Quatrefages, l. c. ii. p. 619,1865 .

$H a b$. Indian Seas (Quatrefages).

16. Phascolosoma elongatum.

Phascolosoma clongatum, Keferstein, Unters. ïb. nied. SeethiereKenntn. in Zeitschr. für wiss. Zool. tom, xii. p. 39, t. 3. f. 5,"1862; Beitr. in l. c. p. 201, 1865.

Sipunculus (Phascolosomum) elongatus, Quatrefages, l. c. ii. p. 619,1865 .

$H a b$. St. Vaast, Normandy (Keferstein). 


\section{Phascolosoma australe.}

Phascolosoma australe, Keferstein, Beitr. in l. c. p. 197, 1865. Sipunculus (Phascolosomum) australis, Quatrefages, l.c. ii. p. 619, 1865.

Hab. Sydney (R. Schütte fide Keferstein).

18. Phascolosoma coriaceum.

Phascolosoma coriaceum, Keferstein, Beitr. in l. c. p. 203, 1865.

Sipunculus (Phascolosomum) coriaceus, Quatrefages, l. c. ii. p. 203,1865 .

Hab. St. Thomas's, West Indies (Riise fide Keferstein).

19. Phascolosoma pellucidum.

Phascolosoma pellucidum, Keferstein, Beitr. in l. c. p. 204, 1865.

Sipunculus (Phascolosomum) pellucidus, Quatrefages, $l$. c. ii. p. 620,1865 .

IIab. St. Thomas's, West Indies (Riise fide Keferstein).

20. Phascolosoma papilliferum.

Phascolosoma papilliferum, Keferstein, Beitr. in l. c. p. 204, 186.j. Sipunculus (Phascolosomum) papillifer, Quatrefages, l. c. ii. p. 620,1865 .

Hab. St. Thomas, West Indies (Riise fide Keferstein).

21. Phascolosoma pygmaum.

Sipunculus (Edematosomum) pygmaus, Quatrefages, l. c. ii. p. 627,1865 .

Hab.

22. Phascolosoma rapa.

Sipunculus (Edematosomum) rapa,Quatrefages,l.c. ii. p. 627, 1865. Hab. —?

23. Phascolosoma margaritaceum.

Phascolosoma margaritaceum, Sars, 1851, fide Keferstein, Nach. Gesell. Wissensch. 1865, p. 201.

Hab. Bergen (Keferstein).

24. Phascolosoma cumanense.

Phascolosoma cumanense, Keferstein, Nach. kön. Gesell. Wissen. Göttirgen, 1866 ; Zeitsch. f. wissen. Zool. Band xvii. p. 53, t. 6 . f. $19,21,1867$.

Hab. Cumana, Venezuela (Couthoy fide Keferstein).

+ Species inhabiting shells belonging to the Mollusca.

(Cryptosomum, Quatrefages.)

1. Phascolosoma bernharnus.

Sipunculus strombus, Montagu, Tr. Linn. Soc, vii. p. 74, 1804 ; 
Turton, Brit. Faun. p. 74, 1807; Fleming, Brit. Animals, p. 491, 1825; Gray, Spic. Zool. p. 8, 1828.

Sipunculus (Cryptosomum) strombi, Quatrefages, Hist. Nat. Ann. ii. p. 628,1865 .

Phascolosomum strombi, Diesing, Syst. Helminth. ii. p. 65, 1851. Phascolosoma strombi, Keferstein, Beitr. z. Anat. Sipunc. l. $c$. p. 202,1865 .

Siphunculus dentalii, Gray, Spic. Zool. p. 8, 1828; Johnston, Loudon's Mag. N. Hist. vi. p. 233, f. 25, 1833.

Phuscolosomum dentalii, Diesing, Syst. Helm. ii. p. 64, 1851.

Sipunculus (Cryptosomum) dentalii, Quatrefages, Hist. Nat. Annel. ii. p. 627, 1865.

Sipunculus bernhardus, Forbes, Brit. Starfish. p. 251, f., 1841; Girard, Stimpson, Contrib. Smithson. 1853, p. 28.

Phascolosoma bernhardus, Pourtalès, Proc. Amer. Ass. Adv. Sc. Meeting v. 1851, p. 41 ; Diesing, Revis. d. Rhyngod. l. c. p. 759, 18.59 .

Sipunculus (Phascolosoma) concharum, Ersted, De Regionib. Marin.p. 80, 1844 ; Kröyer's Nat. Tidssk. 1844-45, p. 419; Sars, Magaz. f. Naturvidensk. 1850, p. 77.

Var. capitata.

Sipunculus capitatus, Rathke, Nov. Act. Nat. Cur. xx. part i, pp. $143-147$, t. 6 . f. $20-23,1843$; O. Schmidt, Zeitsch. f. d. gesammt. Naturw. 1854, pt. 3. p. 2, t. 1. f. 2 .

Phascolosomum capitatum, Diesing, Syst. Helm. ii. pp. 65 and 555,1851 .

Phascolosomum bernhardus, var. capitata, Liesing, Revis. d. Rhyngod. l. c. p. 760, 1859.

Hab. Coasts of England, Scotland, \&c., inhabiting Dentalium- and Stromb-shells, \&c.

a. P. dentalii, Cornwall (Laughrin), Devonshire (J. Cranch). B.M.

b. P. strombus, Devonshire (Montagu), Aberystwith (Henslow).

c. P. dentalii, var. capitata, Yorkshire (W.Clift, Esq.). B.M.

2. Phascolosoma cementarium.

Sipunculus (Cryptosomum) camentarius, Quatrefages, Hist. Nat. Annelés, ii. p. 628, 1865 .

Hab. North America, in Dentalium-shells (M. Richard fide Quatrefages).

$\doteqdot$ Species with skin more or less densely covered with warts or granules.

(Phymosomus, Quatrefages.)

1. Phascolosoma tuberculatum.

Sipunculus tuberculatus, Blainville, Dict. Sc. Nat. art. Siponcle, Atlas, pl. 33. f. 5, 1827. 
Sipunculus verrucosus, Cuvier, Règn, An. 2nd ed. iii. p. 243, 1830 ; Grube, Actin. Echin. und Würm. Adriat. p. 44, 1840.

Phascolosoma granulatum, Leuckart, Brev. desc. An. quor.p. 22, f. 5, 1838; Keferstein, Unters. üb. nied. Seeth. p. 38, 1862 ; Beitr. in l. c. p. 200,1865 .

Phascolosomum granulatum, Diesing, Syst. Helm. ii. p. 63, 1851 ; Revis. der Rhyngod. in l.c. p. 759, 1859.

Sipunculus (Phymosomum) tuberculatus, Quatrefages, l. c. ii. p. 624,1865 .

Hab. Mediterranean, Adriatic (Blainville, Leuckart), Santa Cruz, West Indies (Ersted).

2. Phascolosoma grayi, Baird.

Siphunculus tuberculatus, Gray, Spic. Zool. i.p. 8. no. 4, 1828 (not Blainville, Dict. Sc. Nat, art. Siponcle, 1827).

$\mathrm{Hab}$.

B.M.

The worm described by Blainville under the name of Sipunculus tuberculatus differs considerably from the species described by Dr. Gray under the same name in his 'Spicilegia Zoologica;' and a comparison of Gray's type in the National Collection with De Blainville's figure confirms this opinion. In the present species the caudal extremity terminates in a prolonged acuminated point, studded all over with flattened tubercles like warts. The exsertile part of the body is of considerable thickness, and is, like the opposite extremity, also thickly covered with warts. In De Blainville's species the caudal extremity is rounded and blunt, and the anterior or proboscidal extremity is much more attenuated than the posterior. The name verrucosus wonld have been appropriate; but Cuvier has preoccupied that name; and more lately Hermann Meyer, in the ' Zeitschrift für wissenschaft. Zool.' i. p. 268, gives some anatomical details of a species which he considers the Sipunculus verrucosus, but which Diesing states to be the same as the $S$. tuberculatus of Blainville. As the species described by Blainville takes precedence by a year of Dr. Gray's, I have named it after this zoologist, who has very well defined the species in his 'Spicileg. Zoolog.'

\section{Phascolosoma arcuatum.}

Sipunculus arcuatus, Gray, Spic. Zool. i. p. 8. no. 5, 1828. Hab. India (General Hardwiclie's Collection).

\section{Phascolosoma jefrereysir, sp. nov.}

Corpus atlenuatum, fusiforme, maculis rubris in dorso notalum, striis circularibus transverse cinctum, in medio sparse granulatum, postice et antice dense granulatum, granulis brunneis; pars exsertilis sparse granulata et in dorso rubro cincta; tentaculis retractis.

Long.corp. 14 lin.,proboscistertiam partem corpori æquans; crass. corp. $1 \frac{1}{2}$ lin., proboscidis $\frac{1}{2}$ lin.

IIab. Spezzia (J. G. Jeffieys, Esq.). B.M.

The body of this worm is narrow and cylindrically fusiform in 
shape, rather acuminated posteriorly, slightly narrowed in front. Along the back it is marked with variously shaped reddish marks; it is striated transversely, the striæ distinct, marked with small, flattish, indistinct warts, and more sparingly with elevated brown granules. The caudal extremity is densely and rather strongly granulated, the granules of a reddish-brown colour and elevated. The proboscis at the root, next the body, is also densely granulated; anteriorly it is circularly striated, sparingly granulated, and ringed dorsally with reddish brown. The extremity of the proboscis, in the only specimen we possess, is withdrawn, so that the tentacles cannot be seen.

\section{Phascolosoma fasciatum, sp. nov.}

Corpus cylindricum, transverse obsolete striatum, antrorsum attenuatum, granulis parvis rubris obsitum, postice rolundatum, subito conicum, pars exsertilis perlonga, atienuata, lavis, striis circularibus distinctis cinctu, et in dorso fasciis latis rubris notata; color albidus, maculis rubridis conspersus; tentaculis retractis.

Long. corp. 15 lin., proboscis corpore fere duplo longior; lat. corp. 2 lin., proboscid. 1 lin.

Hab. Madeira (N. Lister, M.D.).

B.M.

The body of the worm is of a whitish colour, obsoletely transversely striated, marked here and there with reddish-brown spots, and covered with small red granules, which are nearly similar in size anteriorly and posteriorly. It is more attenuated anteriorly, and sends out a very long proboscis, which is narrow, not tuberculated, but distinctly circularly striated, and fasciated with interrupted broad bands of brown. Posteriorly the body is blunt, but becomes suddenly pointed at the very extremity. The broad bands of brown on the proboscis, the marks of red on the body, and the small tubercles on the surface are all nearly confined to the dorsal aspect, the abdominal region being nearly white.

Is this the Sipunculus lavis, Cuvier $=$ Phascolosoma lave, Keferstein? In the 'Zeitsch. f. wiss. Zool.' 1867, p. 50, Keferstein mentions having received a specimen $11 \mathrm{~mm}$. long from Fayal, Azores; but in some respects his description differs from that of the species here given.

\section{Phascolosoma placostegi, sp. not.}

Corpus fusiforme, breve, utrinque attenuatum, striis circularibus cinctum, fere lave, parte caudali acuminata, granulis majusculis obsita, parte anteriore verrucis complanatis sparsis instructa, parte exsertili circulariter striata; tentaculis absconditis.

Long. corp. 10 lin., crass. 1 lin.; long. probose. $3 \frac{1}{2}$ lin.

$H a b$. Cape of Good Hope; found lodged in a mass of Serpulæ (Placostegus).

The body is fusiform in shape, a little attenuated at both extremities, rather more so at the caudal termination, which is somewhat acuminated and covered with raised warty-looking granules. The 
body is not verrucose, but is roughened with numerous, close-set, circular striæ near the anterior extremity, showing a few scattered, flattened-looking warty granules. The exsertile portion of the body is attenuated, and circularly striated; but the extremity or proboscis is withdrawn in the only specimen we possess, so that the tentacles cannot be seen. This was found lodged in some of the crevices of a mass of a species of tubicolous Annelides belonging to the genus Placostegus, which formed a portion of the collection of Dr. Krauss ; it was dry, but was afterwards moistened and put into spirits.

\section{Phascolosoma nigriceps, sp. nov. (Pl. XI. figs. 1, 1 a.)}

Corpus fusiforme, antice paulo attenuatum, postice rotundatum, granulis fuscis numerosis circulariter obsitum, parte antica nigra, granulis nigris multo majoribus instructa; pars exsertilis retracta.

Long. corp. fere 2 unc., crassitud. corp. med. $\frac{1}{2}$ unc.

$H a b$. St. Thomas's, West Indies (Mr. Cuming?); Jamaica ( $M r$. Gosse); Chili (Mus. Brit.).

B.M.

The body is of a fusiform shape, slightly attenuated posteriorly, much more so anteriorly, and thicker about the centre. It is covered with numerous, rather small, rounded granules, of a brown colour, with a small white point in the centre, but which, at the anterior extremity, become much larger, rather square-shaped, and so dark as to give the whole of the anterior part, and what can be seen of the exsertile portion, a deep black hue. The proboscis itself, in all the specimens possessed by the Museum, is withdrawn, so that I could not ascertain the appearance of the tentacles. The body, with the exception of the granules and the anterior portion, is of a light colour.

\section{Phascolosoma ethiofs, sp. nov.}

Corpus utriculare, totum nigrum, granulis parvis, in extremitatibus, anteriore presertim, majoribus, obtectum, extremitate caudali conoidea, antica paulo attenuata; pars exsertilis brevis, crassiuscula, spinulis numerosis parvis cbsita ; tentacula brevia, numerosa.

Long. corp. 14 lin., probosc. 3 lin. ; crass. corp. in medio 4 lin.

Hab. St. Vincent's, West Indies (Rev. J. Guilding?). B.M.

The whole body is of a deep black colour, and it is covered with numerous small black granules, which, however, become larger at the extremities, especially anteriorly. The posterior extremity is conoidal, and the anterior is rather attenuated. The exsertile portion is also black, and is roughened with numerous small black spines. The cirri of the proboscis are short and numerous.

9. Phascolosoma perlucens, sp. nov. (Pl. X. figs. 2, $2^{\mathrm{a}}$ ).

Corpus subcylindricum, arcuatum, elongatum, postice paulo attenuatum, pellucido-albidum, granulis minimis sparsis obsitum, dimidia 
pars anterior longitudinaliter sub cute albo lineata; pars exsertilis granulis parvis rubris dense obtecta et rubro vittuta.

Long. corp. 1 unc., crass. $1 \frac{1}{2}$ lin.; long. probosc. $2 \frac{1}{2}$ lin., crass. $\frac{1}{2} \operatorname{lin}$.

Hab. Jamaica; taken out of holes in coral-rocks ( $M r$. Gosse).

B.M.

The body of this worm is slightly arched or curved in form, is somewhat cylindrical, rather slender, much longer than broad, and is of a pellucid white colour, at first appearing smooth and shining, but with the assistance of a lens showing itself to be partially covered with minute light-brown-coloured granules. These are more numerous at the posterior extremity than on the rest of the body, except the exsertile or proboscidal portion, which is thickly covered with small reddish-brown granules and here and there a stain of reddish-brown hue. The upper half of the body is the smoothest, and is marked by a series of longitudinal white lines showing under the integument, and which disappear at about half the length of the body.

\section{Phascolosoma albo-lineatum, sp. nov.}

Corpus subcylindricum, arcuatum, subpellucidum, in medio punctis seu granulis minimis sparse obsitum, extremitatibus utrinque subattenuatis, granulis majoribus rubro-fuscis obtectis; pars anterior lavis, sub cute longitudinaliter albo lineata; pars exsertilis longa, postice granulis parvis rubris, antice lavis, rubro maculata, et prope extremitatem lineis nigris exilibus viginti circumdata; proboscis cirris curtis paucis violascentibus induta.

Long. corp. $1 \frac{3}{4}$ unc., long. part. exsert. 1 unc.; crass. corp. in medio 2 lin., crass. probose. $\frac{1}{2}$ lin.

Hab. Philippine Islands (Mr. Cuming's Collection). B.M.

This species is much larger than the preceding, but resembles it in many respects. The body is arched or curred in form, and is somewhat translucid, especially the upper or anterior half, which is smooth and shining to appearance, and is marked under the skin with numerous longitudinal white lines. Under the lens the middle of the body appears covered partially with very minute point-like granules, which enlarge at each extremity and become more numerous. The caudal extremity is conoidal, rather sharp-pointed, and the granules are like raised warty projections; the anterior extremity is rather attenuated, the exsertile portion being of considerable length, more than half the length of the body. It is covered at the base with numerous reddish-brown granules, is smooth on the anterior portion, is marked with reddish-brown-looking stains, and near the extremity is surrounded with about twenty very fine black rings, each ring being composed of numerous very small spines. The proboscis does not at first sight seem to be provided with any cirri; upon more attentive examination, however, they appear to be very short, few in number, and of a violet hue. The only history we have of this species is, that it was found in the Philippine Islands; but I should be disposed to consider, from its general resemblance 
to the foregoing (P. perlucens), that it was found burrowing like it in holes in coral-rocks.

\section{Phascolosoma noduliferum.}

Phascolosomum noduliferum, Stimpson, Proc. Acad. Philad. tom. viii. p. 375, 1855 ; Diesing, Rev. der Rhyngod. l. c. p. 761, 1859.

Phascolosoma noduliferum, Keferstein, Beitr. in l.c. p. 198, 1865.

Sipunculus (Phymosomum) nodulosus, Quatrefages, l.c. ii. p. 621. no. 30,1865 .

Sipunculus (Phymosomum) noduliferus, Quatrefages, l.c. ii. p. 624. no. 42,1865 *.

$H a b$. Australia, Sydney (J. M'Gillivray); Nicol Bay, north coast of Australia (M. de Boulay); Australia (J. B. Jukes, Esq.). B.M.

\section{Phascolosoma agassizit.}

Phascolosoma agassizii, Keferstein, Nach. d. kön. Gesellsch. der Wissensch. in Göttingen, 1866 ; Zeitsch. für wissensch. Zool. Band xvii. Heft i. p. 46 , t. 6 . f. $3-8,1867$.

Phascolosoma Hawkinsii, Baird, MS. in Mus. Brit.

Hab. California and Panama (Agassiz fide Keferstein); Esquimalt Harbour, Vancouver Island (Licut.-Col. Hawkins).

B.M.

I had named this species after Lieut.-Col. Hawkins, H.M. Commissioner on the North-American Boundary Survey, who collected the specimens, and to whom we are indebted for them. There are two specimens, one much more slender than the other. This has the exsertile portion protruded; the other has it withdrawn, which may account for the difference in circumference.

\section{Phascolosoma lordi, sp. nov.}

Corpus brevifusiforme, griseum, transverse rugosum, granulis parvis fuscis obsitum, ad extremitatem posteriorem coacervatis, ad extremitatem anteriorem sparsis; pars exsertilis cylindrica, brevis, rugibus circularibus circumdata.

Long. corp. 1 une., part. exsert. 4 lin.

$H a b$. Esquimalt Harbour, Vancouver Island (J. K. Lord, Esq.).

B.M.

The body of this animal is of a greyish colour, wrinkled across with transverse rugæ, or, as it were, corrugated. The skin is covered with very small light-brown granules, which at the posterior extremity are larger, darker-coloured, and more numerous, and at the anterior extremity are very few and scattered at intervals. The exsertile portion is rather short, cylindrical in form, and rugose. The tentacles are withdrawn. We have only one specimen of this species, which differs very much from the preceding in general appearance, size, and colour, though collected at the same place. I have named it after Mr. J. K. Lord, who was the naturalist attached

* Quatrefages has, evidently in mistake, quoted this species twice over, but has, in the first instance, given it the name of nodulosus. The synonyms he has quoted are the same in both instances. 
to the North-American Boundary Survey under Col. Hawkins. It may possibly be only a variety of the preceding species.

\section{Phascolosoma planispinosum, sp. nov.}

Corpus sacciforme, albo-griseum, granulis brunneis minutis oblectum, granulis ad extremitatem posticam in spinis latis mutatis; pars exsertilis partem tertiam corporis aquans, spinis latis, majoribus, brunneis obtecta; tentaculis retractis. lin.

Long. corp. 6 lin., part. exsert. 4 lin. ; corp. crass. usque ad $3 \frac{1}{2}$

Hab. — ? (Mr. Cuming's Collection).

B.M.

The body of this species is of a light greyish colour, deeper at the two extremities, where the minute granules with which the body is covered are replaced by flat sharp-pointed spines, standing out nearly erect from the skin. The exsertile portion is particularly marked in this manner, the spines being numerous and larger than at the posterior extremity. The shape of the body is very similar to that of Sipunculus (Phascolosoma) genuensis of Blainville, but differs in being very much smaller and having the exsertile portion, comparatively speaking, longer, and being very rough with the flat spines. Unfortunately we have only one specimen, which was collected by the late Mr. Cuming, but no habitat was attached to it.

\section{Phascolosoma multitorquatum.}

Sipunculus (Phymosomum) multitorquatus, Quatrefages, l. c. ii. p. $621,1865$.

Hab. Guettary (Quatrefages).

16. Phascolosoma spinicauda. 1865 .

Sipunculus (Phymosomum) spinicauda, Quatrefages, l. c. ii. p. 621,

Hab. Barcelona (Q.atrefages).

17. Phascolosoma guttatum. 1865.

Sipunculus (Phymosomum) guttatus, Quatrefages, l.c. ii. p. 621,

Hab. Red Sea (Quatrefages).

18. Phascolosoma orbiniense.

Sipunculus (Phymosomum) orbiniensis, Quatrefages, l.c. ii. p.622, 1865 .

Hab. American seas (M. d'Orbigny).

19. Phascolosoma plicatum. 1865 .

Sipunculus (Phymosomum) plicatus, Quatrefages, l. c. ii. p. 622,

$H a b$. ?Indian seas (Quatrefag'es). 
20. Phascolosoma Javanense. 1865 .

Sipunculus (Phymosomum) javanensis, Quatrefages, l. c. ii. p. 622,

Hab. Java (Quatrefages).

21. Phascolosoma constellatum.

Sipunculus (Phymosomum) constellatus, Quatrefages, l. c. ii. p. 622,1865 .

$H a b$. Isle of France (Quatrefages).

22. Phascolosoma cochlearium :

Sipunculus cochlearius, Valenciennes, Comptes Rendus, tom. xxxix. p. 641,1854 .

Sipunculus (Phymosomum) cochlearius, Quatrefages, l. c. ii. p. 623,1865 .

$H a b$. Indian seas, in coral (Qua'refages).

23. Phascolosoma nigrescens.

Phascolosoma nigrescens, Keferstein, Beitr. in l. c. p. 198, 1865. Sipunculus (Phymosomum) nigrescens, Quatrefages, l.c. ii. p. 623, 1865 .

Hab. Fiji Islands (Viti) (Dr. Gräffe fide Keferstein).

24. Phascolosoma varians.

Phascolosoma varians, Keferstein, Nach. kön. Ges. Wissen. p. 199,1865 ; Zeitsch. f. wiss. Zool. Band xv. pp. 424-426, t. 31 . f. 3 , t. 32 . f. 22,1865 ; Band xvii. p. $48,1867$.

Phascolosoma puntarena, Keferstein, Unters. über nied. Seethiere, in Zeitsch. f. wiss. Zool. tom. xii. p. 40, t. 3. f. 1, 6, 12, 15, 1862 . 1865.

Sipunculus (Phymosomum) varians, Quatrefages, l. c. ii. p. 623,

Hab. St. Thomas, West Indies (Riise), Florida (Agassiz fide $\boldsymbol{K} \boldsymbol{e}$ ferstein).

\section{Phascolosoma cylindratum.}

Phascolosoma cylindratum, Keferstein, Beitr. in l. c. p. 200, 1865. Sipunculus (Phymosomum) cylindratus, Quatrefages, l. c. ii. p. 623,1865 .

Hab. Bermuda (Riise fide Keferstein).

26. Phascolosoma loricatum.

Lithodermus cuncus?, Cuvier, R. An. 2nd edit. iii. p. 242, 1830.

Sipunculus (Phymosomum) loricatus, Quatrefages, l.c. ii. p. 623, 1865 .

Hab. New Holland (Quatrefages).

27. Phascolosoma puntarena.

Phascolosoma puntarena, Grube et Ersted, Annul. Ersted. p. 13, 1858, not Keferstein, Unters. n. Thier. p. 40, 1863. 
Phascolosomum puntarena, Diesing, Rev. der Rhyng. p. y o 1, 1859. Sipunculus (Phymosomum) puntarenc, Quatrefages, l.c. ii. p. 624, 1865 .

Hab. Puntarenas (Ersted).

28. Phascolosoma genuense.

Sipunculus genuensis, Blainville, Dict. Sc. Nat. art. Siponcle, Atlas, t. 33. f. 4, 1828.

Phascolosomum genuense, Diesing, Rev. der Rhyngod. in l. $c$. p. $761,1859$.

Phascolosoma lima, Costa, Faun. del Regn. di Napoli, Annelid. pl. .f. , 18 ?

Phascolosomum lima, Diesing, l. c. p. 761, 1859. 1865 .

Sipunculus (Phymosomum) genuensis, Quatrefages, $l$. c. ii. p. 625,

Hab. Coast near Genoa (Blainville); near Naples (Costa).

29. Phascolosoma granulosum.

Syrinx granulosus, M'Coy, Ann. \& Mag. Nat. Hist. tom. xv. p. 272 , t. 16, f. 2,1845 .

Phascolosomum granulosum, Diesing, Syst. Helminth. ii. p. 63, 1851 ; Revis. d. Rhyng. in l. c. p. 761, 1859. 1865 .

Sipunculus (Phymosomum) granulosus, Quatrefages, l.c. ii. p. 625,

$\mathrm{Hab}$. Roundstone Bay, Ireland ( $\left.\mathrm{M}^{`} \mathrm{Coy}\right)$.

30. Phascolosoma papillosum.

Sipunculus papillosus, Thompson, Ann. \& Mag. vol. v. p. 101, 1840.

Syrinx papillosus, Forbes, Brit. Starfishes, p. 247, fig., 1841.

Phascolosomum papillosum, Diesing, Revis. der Rhyngod. in l. c. p. $762,1859$.

Sipunculus (Phymosomum) papillosus, Quatrefages, l.c. ii. p. 625, 1865 .

Hab. Miltown Bay, \&c., Ireland (Thompson).

31. Phascolosoma johnstoni.

Sipunculus johnstoni, Forbes, Brit. Starfishes, p. 254, fig., 1841. Phascolosomum johnstoni, Diesing, Revis. d. Rhyng. in l. c. p. $762,1859$.

Sipunculus (Phymosomum) johnstoni, Quatrefages, l.c. ii. p. 625, 1865 .

Hab. Berwick Bay (Johnston).

32. Phascolosoma longicolle.

Phascolosomum longicolle, Leuckart and Rüppell, Atlas z. der Reise im nördl. Afr. Zooph. p. 6, t. 2. f. 1, 1828.

Sipunculus (Phymosomem) longicollis, Quatrefages, l.c. ii. p. 625, 1865 .

Hab. Red Sea (Rïppell). 


\section{Phascolosoma antillarum.}

Phascolosomum antillarum, Grube \& Ersted, Annulat. Ersted. p. 13, 1858; Diesing, Revis. d. Rhyngod. in l. c. p. 762, 1859.

Phascolosoma antillarum, Keferstein, Beitr. in l.c. p. 205, 1865; Unters. Nied. Seethiere in Zeitsch. f. wiss. Zool. Band xii. p. 40, 1862, t. 3. f. 2,11 ; Band xv. p. 435,1865 , t. 31.f. 11, t. 33. f. 37 , and Band xvii. p. 54, 1867.

Sipunculus (Phymosomum) antillarum, Quatrefages, l.c. ii. p. 626, 1865 .

Hab. Puntarenas and Santa Cruz (Ersted); St. Thomas, West Indies (Keferstein); Panama (Agassiz).

\section{Phascolosoma glans.} 1865.

Sipunculus (Edematosomum) glans, Quatrefages, l. c. ii. p. 626,

Hab. ? Indian Seas (Quatrefages).

35. Phascolosoma im modestum*.

Sipuncutus (Edematosomum) immodestus, Quatrefages, l.c. ii. p. 627,1865 .

Hab. Indian Seas (Quatrefages).

\section{Phascolosona lave.} 1830 .

Sipunculus lavis, Cuvier, Règne An. 2nd ed. tom. iii. p. 243,

Phascolosoma lave, Keferstein, Zeitsch. f. wiss. Zool. Band xii. p. 38, t. 3.f. 4, 1862 ; Band xv. p. 427, t. 31. f. 6 , t. 32. f. 20,21 ; 1865; Band xvii. p. 50, t. 6. f. 14, 1867 ; Beitr. in l.c.p. 200, 1865.

? Phascolosoma fasciatum, Baird, see sp. 5.

Hab. Sicily (Cuvier, Keferstein); Fayal, Azores (Higginson fide Keferstein).

\section{Phascolosoma riiseit.}

Phascolosoma riisei, Keferstein, Beitr. in l. c. p. 206, 1865.

$H a b$. St. Thomas, West Indies (Riise fide Keferstein).

\section{Phascolosoma pectinatum.}

Phascolosoma pectinatum, Keferstein, Nach. königl. Gesellseh. Wissensch. Göttingen, 1866; Zeitsch. f. wissensch. Zool. Band xvii. p. 47 , t. 6 . f. $9-12,1867$.

Hab. Panama (Agassiz fide Keferstein).

39. Phascolosoma pacificum.

Phascolosoma pacificum, Keferstein, Nach. kön. Gesell. Wissen. Göttingen, 1866; Zeitsch. f. wissen. Zool. Band xrii. p. 49, t. 6 . f. $1-2,1867$.

Hab. Kingsmill Island, Gilbert Group, Pacific (Keferstein).

* Quatrefages does not mention, in his description of this species, whether it is smooth or tubereulated. 
Species considered doubtful, or not sufficiently described.

40. Phascolosoma nordfolcense.

Sipunculus nordfolcensis, Brandt, Prod. Descript. Animal. ab Mertens. observat. p. 61, 1835; Dujardin in Lamarck, An. s. Vertèb. (2nd edit.) iii. p. $470,1840$.

Phascolosomum nordfolcense, Diesing, Syst. Helm. ii. p. 67, 1851 ; Revis. d. Rhyngod. l. c. p. 765, 1859; Dujardin, Hist. Nat. Ann. ii. p. 631,1865 .

Hab. Norfolk Sound (Mertens).

41. Phascolosoma fasciolatum.

Sipunculus fasciolatus, Brandt, Prod. Desc. An. Mertens. obs. p. 61,1835 .

Phascolosomum fasciolatum, Diesing, Syst. Helm. ii. p. 66, 1851; Revis. d. Rhyngod. l. c. p. 765,1859 ; Dujardin, l. c. ii. p. 631 , 1865 .

Hab. Island of Ualan, Caroline Islands (Mertens).

42. Phascolosoma ambiguum.

? Sipunculus ambiguus, Brandt, Prod. An. Mertens. obs. p. 62, 1835.

Phascolosomum ambiguum, Diesing, Syst. Helm. ii. p. 67, 1851; Revis. d. Rhyng. l.c.p. 765, 1859; Dujardin, l. c. ii. p. 631, 1865. Hab. - ? (Mertens).

43. Phascolosoma tigrinum.

Sipunculus tigrinus, Risso, Hist. nat. Europ. mérid. v. p. 292, 1826; Guérin, Icon. Règ. An. Cuv. Zooph. t. v. f. 4, 1834 ?.

Phascolosoma granulatum, Leuckart? fide Diesing; Joh. Müller, Wiegm. Archiv, 1844, p. 168.

Phascolosomum tigrinum, Diesing, Syst. Helm. ii. p. 66, 1851; Revis. d. Rhyng. l. c. p. 765,1859 ; Dujardin, $l$. c. ii. p. 631, 1865.

Hab. Nice, amongst Fuci (Risso).

\section{Phascolosoma flavum.}

Sipunculus favus, Risso, Hist. nat. Eur. mérid. v. p. 292, 1826. Phascolosomum granulatum, Leuckart?; Joh. Müller, Wiegm. Archiv, 1844, p. 168 (quoted by Diesing).

Phascolosonum flavum, Diesing, Syst. Helm. ii. p. 66, 1851 ; Revis. d. Rhyng. l.c. p. 765, 1859; Dujardin, l. c. ii. p. 631, 1865 . Hab. Nice (Risso).

\section{Phascolosoma leachit.}

Sipunculus leachii, Blainville, Dict. Sc. Nat. xlix. p. 312, 1827. Phascolosomum leachii, Diesing, Syst. Helm. ii. p. 67, 1851; Revis. d. Rhyngod. l.c. p. 765,1859 ; Dujardin, l.c. ii. p. 631, 1865 .

$$
\text { Hab. — ? (Leach). }
$$

Proc. Zool. Soc.-1868, No. VII. 


\section{Phascolosoma pourtalesi.}

Sipunculus granulatus, Pourtalès, Proc. Amer. Ass. Adv. Sc. 1851, p. 41.

Phascolosomum pourtalesi, Diesing, Revis. der Rhvngod. l. c. p. 765,1859 .

Hab. Florida (Pourtalès).

\section{Genus 3. Petalostoma.}

Phascolosoma (sp.), Keferstein, 1862.

Petalostoma, Keferstein, 1865.

\section{Petalostoma minutum.}

Phascolosoma minutum, Keferstein, Unter. niedere Seethiere in Zeitsch. f. wissensch. Zool. Band xii. p. 40, t. 3. f. 7-10, 1862.

Petalostoma minutum, Keferstein, Beitr. Nach. kön. Gesellsch. Göttingen, p. 207*, 1865; Quatrefages, l. c. ii. p. 631, 1865.

$H a b$. St. Vaast, Normandy (Keferstein).

\section{Genus 4. Themiste.}

Themiste, Gray, Spicilegia Zoolog. p. 8, 1828.

Dendrostomum, Grube \& Ersted, Annulat. Ersted, p. 14, 1858; Diesing, Rev. d. Rhyngod. 1859; Quatrefages, $l$. c. ii. p. 629, 1865 , Dendrostoma, Keferstein, Beitr. z. Anat. Sipunc. in Nach. könig. Gesellsch. Göttingen, p. 207, 1865.

\section{Themiste hennahi.}

Themiste hennahi, Gray, Spic. Zool. p. 8, 1828.

Hab. Peru (Rev. W. Hennah).

B.M.

\section{Themiste alutacea.}

Dendrostomum alutaceum, Grube \& CErsted, Annulat. CErsted. p. 14, 1858; Diesing, Revis. der Rhyngod. in l. c. p. 765, 1859 ; Quatrefages, $l . c$. ii. p. 630, 1865.

Hab. Santa Cruz, West Indies ( $E r s t e d)$.

\section{Themiste pinnifolia.}

Dendrostoma pinnifolium, Keferstein, Beitr. in l.c. p. 207, 1865. Dendrostomum pinnifolium, Quatrefages, l. c. ii. p. 630, 1865. Hab. St. Thomas's, West Indies (Riise).

\section{Themiste ramosa.}

Dendrostomum ramosum, Quatrefages, l.c. ii. p. 629, 1865. Hab. Brazil (Quatrefages).

5. Themiste lageniformis. (Pl. X. figs. $3-3^{\mathrm{c}}$.)

Corpus cum proboscide exserta lageniforme, lave, corrugatum, * P. miuntum ! evidently a misprint for minutum. 
transverse rugoso-striatum, rotundato-inflatum, extremitate postica in mucronem obtusum desinente, antica paulo attenuata; pars exsertilis longa, cylindrica, rugoso-plicata; tentaculis 6 ? in pinnulas numerosas divisis.

Long. corp. 6 lin., crass. 5 lin.; long. part. exsert. 5 lin.

$H a b$. ? Australia (Earl of Derby's Coll).

B.M.

This species, which is one of many specimens of natural history collected for the late Earl of Derby by the late John Macgillivray, appears different from all the others in our collection. When the exsertile portion is protruded, it is completely bottle-shaped, and the skin is entirely free from granulations. It is, however, wrinkled, transversely finely striated and rugose, and at the posterior extremity is almost clathrate. This portion of the body is rounded, inflated, and terminates in a blunt conical point. The exsertile portion is of considerable length, is cylindrical in shape, and rugosely plicate. The tentacles or cirri are short and much pinnated.

We possess two specimens of this species-one with the exsertile portion and tentacula protruded, from which the diagnosis is chiefly drawn up, and which apparently, when collected, had been allowed to dry, and has thus, to outward appearance, become almost smooth; when examined, however, more carefully, the skin is seen to be wrinkled and transversely striated. In the other specimen the proboscis is almost entirely withdrawn, and the skin is much more distinctly wrinkled and striated. At first sight they appear to be distinct species; but as they come from the same locality, I am led to believe them the same.

Genera of Sipunculidæ not sufficiently established, and the position of which is doubtful.

Genus 1. Ascosoma.

Ascosoma, Leuckart, Brev. Animal. quor. Descript. 1828 ; Quatrefages, $l . c$. ii. 1865 .

Ascosomum, Diesing, Syst. Helminth. ii. p. 75, 1851; Revis. d. Rhyngod. in l.c. p. 778, 1859.

\section{Ascosoma blumenbachit.}

Ascosoma blumenbachii, Leuckart, Brev. Animal. quor. Descrip. p. 21 , t. 1. f. 4 , 1828 ; Quatrefages, $l$. $c$. ii. p. 630,1865 .

Ascosomum blumenbachii, Diesing, Syst. Helminth. ii. p. 76, 1851 ; Revis. d. Rhyngod. in l.c. p. 778, 1859.

Phascolosoma granulatum, Leuckart? Joh. Müll. Wiegm. Arch. p. $168,1844$.

Hab. Mediterranean, near Cette (Leuckart).

\section{Genus 2. Anoplosomatum.}

Anoplosomatum, Grube, Act. Echin. Würm. Adriat. p. 47, 1840 (charact. emend.); Diesing, Syst. Helm. ii. p. 68, 1851; Revis. d. 
Rhyng. in l. c. p. 766, 1859 ; Quatrefages, $l . c$. ii. p. 630, 1865 ; Keferstein, Beitr. in l.c. p. 209, 1865.

Lanceola, Blainville, Dict. Sc. Nat. lvii. art. Vers, p. 553, 1828.

\section{Anoplosomatum .utriculus.}

Anoplosomatum utriculus, Grube, Actin. Echin. Würm. Adriat. p. 48 , t. 1. f. 3 , 1840 ; Diesing, Syst. Helminth. ii. p. 69 ; Revis. d. Rhyngod. in l. c. p. 766, 1859; Quatrefages, l.c. ii. p. 631, 1865. Hab. Mediterranean, near Palermo (Grube).

\section{2. ? Anoplosomatum paretti.}

Lanceola paretti, Blain. l. c. art. Vers, 1828.

Anoplosomatum paretti, Diesing, Syst. Helm. ii. p. 69, 1851; Revis. d. Rhyngod. in l. c. p. 776, 1859; Quatrefages, $l$.. . ii. p. 631,1865 .

\section{Anoplosomatum antillense.}

Anoplosomatum antillense, Steenstrup, Keferstein, Beitr. in l.c. p. $209,1865$.

Hab. St. Ian, West Indies (Prosch, Suenson, fide Keferstein).

\section{? Genus 3. Dichidosiphon.}

Diclidosiphon, Diesing, Revis. d. Rhyngod. 1859.

Sipunculus, sp., Lesson, Quatrefages.

\section{DiCLIDOSIPHON LUMBRICIFORMIS.}

Sipunculus lumbriciformis, Lesson, Cent. d. Zool. p. 152, t. 53. f. 3,1830 .

Sipunculus (Phymosomum) lumbriciformis, Quatrefages, l.c. ii. p. 626,1865 .

Diclidosiphon lumbriciformis, Diesing, Syst. Helminth. ii, p. 70, 1851 ; Revis. d. Rhyngod. in l.c.p. 766, 1859.

Hab. Falkland Islands (Lesson).

Family II. Aspidosiphonide.

Eusipunculidea, Aspidosiphones (part.), Diesing. Aspidosiphonea, Quatrefages.

\section{Genus 1. Aspidosiphon.}

Aspidosiphon, Diesing, Syst. Helm. ii. p. 67, 1851; Revis. der Rhyngod. l. c. p. 767, 1859; Quatrefages, l. c. ii. p. 608, 1865.

Sipunculus, sp., Blainville.

Sipunculus (Phascolosomum), sp., Joh. Müller.

Lesinia, O. Schmidt, Zeitsch. f.' d. gesammt. Naturwiss. 1854, tom. iii. p. 2; Diesing, Revis. der Rhyngod. l.c. p. 779, 1859; Quatrefages, l.c. p. 599, 1865. 


\section{(Anus dorsalis.)}

\section{Aspidosiphon mülleri.}

Sipunculus (Phascolosomum) scutatus, Joh. Müller, in Wiegm. Archiv, tom. xix. p. 166-168, t. 5. f. A-D, 1844; Krohn, in Müll. Archiv, p. 371, 1851.

Aspidosiphon mülleri, Diesing, Syst. Helminth. ii. pp. 68 \& 556; Revis. der Rhyngod. l.c. p. 767,1859; Quatrefages, l.c. p. 609, 1865 ; O. Schmidt, Mitth. Nat. Verein. Steirmark, p. 56, 1865.

Lesinia farcimen, O. Schmidt, Zeitsch. f. d. gesammt. Naturwiss. 1854, vol. iii. p. 2, t. 1. f. 3 ; Diesing, Revis. der Rhyngod. l.c. p. 779, 1859; Quatrefages, l.c. p. 599, 1865.

Hab. Mediterranean (Grohman \& Krohn); Lesina (Schmidt); off the Shetland Isles (J.G. Jeffreys).

B.M.

Notwithstanding the difference of habitat, I cannot distinguish any marks by which to separate our specimen from the species found in the Mediterranean. It is perhaps less narrow posteriorly; and the small brown points or papillæ, as Diesing terms them, on the body, are smaller than in the species figured by Müller. The Phascolosoma radiata of Alder, found in the same locality, and described by him in the 'Annals and Magazine of Natural History' in 1860 , approaches in some respects this species, and may possibly be synonymous with it. The description given by $\mathrm{Mr}$. Alder is rather indefinite, and a further examination of fresh specimens is necessary to elucidate the point.

\section{Aspidosiphon STEENSTRUPII.}

Aspidosiphon steenstrupii, Diesing, Revis. der Rhyngod. l. c. p. 767, 1859; Icon. Zoogr. Ferdinand. I. Imperatoris; Quatrefages, l. c. p. 610,1865 .

Hab. Island of St. Thomas, West Indies (Riise fide Diesing).

\section{Aspidosiphon rhyssaspis.}

Aspidosiphon rhyssaspis, Diesing, Revis. der Rhyngod. l. c. p. 768, 1859; Icon. Zoogr. Ferdinand. I. Imperatoris; Quatrefages, l.c. p. 610,1865 .

Hab. West Indies (Suenson fide Diesing).

\section{Aspidosiphon eremita.}

Aspidosiphon eremita, Diesing, Revis. der Rhyngod. l.c. p. 768, 1859 ; Icon. Zoogr. Ferd. I. Imperat.; Quatrefages, l. c. p. 610, 1865 .

Hab. Madeira (Dr. Lister) ; inhabiting empty shells of Ditrupa (Diesing).

B.M.

5. Aspidosiphon coyi.

Aspidosiphon coyi, Quatrefages, l. c. p. 608, 1865.

Hab. Indian seas? (Quatrefages). 
6. Aspidosiphon Leve.

Aspidosiphon lave, Quatrefages, l.c. p. 609, t. 20. f. 23, 24 . Hab. Indian seas? (Quatrefages).

7. Aspidosiphon cumingir, sp. nov. (Pl. XI. fig. 2.)

Corpus cylindricum, fuscum, antice densissime, postice paululum verrucosum, in medio rugosum et circulariter striatum; scutellum anterius subellipticum, brunneum, longitudinaliter sulcatum, posterius centrifuge sulcatum, sulcis dichotomis ; proboscis brevis, cylindrica, gracilis, rugosa, fasciata.

Long. corp. 3 unc., lat. 7 lin.; long. probosc. 8 lin.

Hab. Philippine Islands (Cuming).

B.M.

This is the largest species I have seen. Anteriorly it is densely granularly tuberculated for nearly an inch in length, posteriorly for only a very short distance. In the middle the body is circularly striated and longitudinally ribbed, as it were, with pellucid ribs. It is of a brownish colour, much deeper at the two extremities, and marked with scattered granulations. The anterior scutellum is of a somewhat oval or elliptic shape, broadly sulcated longitudinally, near the proboscis tubercularly granulated, and at a short distance from where it terminates on the body it is keeled. The posterior scutellum is circular, is marked by the same kind of sulci as the anterior, but radiately disposed and dichotomously divided towards the external margin. It is separated from the lower part of the body by a sharp keel which surrounds it. The proboscis is rugose, slender, and short, is of a light colour at its two extremities, and peculiarly marked in the middle with a broad band of a deep brown.

\section{Aspidosiphon trunCatum.}

Phascolosoma truncatum, Keferstein, Nach. kön. Gesell. Göttingen, 1866.

Phascolosoma (Aspidosiphon) truncatum, Keferstein, Zeitsch. f. wissensch. Zool. Band xvii. p. 50, t. 6. f. 15-18, 1867.

Hab. Panama (Agassiz fide Keferstein).

\section{Aspidosiphon radiatum.}

Phascolosoma radiata, Alder, Ann. \& Mag. Nat. Hist. 3rd ser. v. p. 75 , t. 5. f. $4-6,1860$. 1865 .

Sipunculus (Cryptosomum) radiatus, Quatrefages, l. c. ii. p. 629,

Hab. Shetland Isles, in shells of Aporrhais (Barlee fide Alder).

Genus 2. Pseudaspidosiphon, Baird.

Corpus gracile, duabus opacitatibus, scutella simulantibus, instructum. Extremitas posterior conica, centrifuge radiata; extremitas anterior, scutello destituta, opaca. Cetera ut in Aspidosiphone. 


\section{Pseudaspidosiphon clavatum.}

Sipunculus clavatus, Blainville, Dict. Sc. Nat. tom. xlix. art. Sipunculus, Atlas, t. 33. f. 2, 1828.

Aspidosiphon clavatum, Diesing, Syst. Helminth. ii. p. 68, 1851. Aspidosiphon clavatus, Diesing, Revis. der Rhyng. l.c. p. 768, 1859; ? Quatrefages, l.c. p. $611,1865$.

Hab. Mediterranean (Blainville).

Quatrefages says of this species that the figure given of it by Blainville in the work quoted above does not represent the anterior scutellum so characteristic of the genus, and which is found in all the other species described. The posterior extremity is conical and centrifugally radiated, but does not appear to have a regular scutellum. The same may be said of the next species, which is said by Diesing to belong doubtfully to the genus Aspidosiphon. I have therefore made a new genus for the reception of these two species, and for a third, which does not appear to have been previously described.

\section{Pseudaspidosiphon spratti.}

Sipunculus, sp., Spratt, Lond. Edin. \& Dublin Philosoph. Magaz. xxxiii. p. 171, 1848 . 1859.

Aspidosiphon? spratti, Diesing, Revis. der Rhyngod. l.c.p. 768,

Hab. Near the island of Malta, at 320 fathoms depth (Spratt).

3. Pseudaspidosiphon gracile, sp. nov. (PI. X. figs. $1,1^{\mathrm{a}}$.)

Corpus gracile, elongatum, cylindricum, striis circularibus cinctum, et granulis parvis, numerosis, brunneis obsitum, parte caudali conoidea, subito acuminata, centrifuge radiata, parte anteriore infra proboscidem attenuatam scutelliformi, brunnea, longitudinaliter rugoso-verrucosa; pars exsertilis attenuata, granulis minimis obsita; ; proboscis retracta.

Long. corporis $2 \frac{1}{4}$ unc., crass. $1 \frac{1}{2}$ lin.; long. proboscid. $\frac{1}{2}$ unc., crass. $\frac{1}{2}$ lin.

Hab. Philippine Islands (Mr. Cuming).

B.M.

The body of this peculiar species is long and slender, circularly striated, the interspaces between the striæ regularly beset with numerous small brown granules. The caudal portion terminates abruptly in a short conical point, which is longitudinally centrifugally striated, while the upper portion of the body just beneath the exsertile portion is of a dark brown colour, and longitudinally granulously striated, the two extremities resembling a good deal the scutella of the genus Aspidosiphon. The colour of the body is of a light yellowish hue, the two extremities (which show the resemblance to the scutella) being of a darker brown, resembling in this respect the Sipunculus clavatus, as represented by Blainville in his figure in the Atlas of the Dict. des Sc. Nat.

Family III. Loxosiphonide.

Eusipunculidea, Aspidosiphones (part.), Diesing, Rev. Rhyng. 1859 . Loxosiphonea, Quatrefages, Hist. Nat. Ann. ii. p. 604, 1865. 


\section{(Anus terminalis.)}

\section{Genus 1. Loxosiphon.}

Loxosiphon, Diesing, 1851 ; Quatrefages, 1865.

Sternaspis, sp., Chamisso \& Eysenhardt.

Sipunculus, sp., Blainville.

\section{LoxosiphoN ELEGANS.}

Sternaspis elegans, Chamisso \& Eysenhardt, Nov. Act. Nat. Cur. tom. x. p. 351 , t. 24 . f. $5 a-e, 1820$.

Sipunculus elegans, Blainv. Dict. Sc. Nat. art. Siponcle, Atlas, t. 26. f. 2 (copied from Cham. \& Eysenh.), 1828.

Loxosiphon elegans, Diesing, Syst. Helm. ii. p. 70, 1851 ; Revis. Rhyng. l.c. p. 769, 1859 ; Quatrefages, Hist. Ann. ii. p. 605, 1865. Hab. Island of Radack, Pacific Ocean (Chamisso).

2. Loxosiphon ASPERgillum.

Loxosiphon aspergillum, Quatrefages, Hist. Nat. Annel. ii. p. 605, t. 20. f. 20,1865 .

$\mathrm{Hab}$. Isle of France (Quatrefages).

Genus 2. Diesingia.

Diesingia, Quatrefages, ii. p. 606, 1865.

1. Diesingia chamissoi.

Diesingia chamissoi, Quatrefages, Hist. Nat. Annel. ii. p. 606, t. 20 . f. 22,1865 .

$\mathrm{Hab}$. ?

\section{Diesingia cupulifera.}

Diesingia cupulifera, Quatrefages, $l$. c. p. 607, t. 20. f. 21, 1865 . Hab. ? Indian seas (Quoy \& Gaimard fide Quatrefages).

Family IV. Priapulide.

Priapulidea, Diesing, 1851 \& 1859.

Priapulea, Quatrefages, l.c. p. 600, 1865.

Priapulacea, Keferstein, Nach. Gesellsch. Wissensch. Götting. 1865.

\section{Genus 1. Priapulus.}

Priapulus, Lamarck, 1816 ; Blainville, 1828 ; Cuvier, 1830 ; Edwards; Forbes, 1841 ; Diesing, 1851 \& 1859 ; Ehlers, 1862 ; Quatrefages, 1865, \&c.

Priapus, Linnæus.

Holothuria, sp., Müller, Linnæus.

\section{Priapulus caudatus.}

Holothuria priapus, Linnæus, Syst. Nat. 12th ed. p. 1091 (synonym. et habitat partim exclusis), 1766 ; Gmelin, Linn. Syst. Nat. 
p. 3140. no.9, 1789 ; Müller, O. F., Zool. Dan. Prod. no.2807, 1776; Zool. Danicæ, tom. iii. p. 27, t. 96. fig. infera, 1789; Fabricius, Faun. Grœnland. p. 355. no. 347, 1780; Abildgaard, in Schrift. der Gesellsch. naturf. Freunde zu Berlin, tom. ix. p. 133, t. 3. f. 1-3, 1789 ; Rathke in Zool. Dan. iv. pp. 18-19, ? t. 135. f. 2, 1784.

? Priapus humanus, Linnæus, Amœn. Acad. tom. iv. p. 255, 1754 ?

Madkomoder, Olafsen \& Povelsen, Reyse igiennem Island, Deel ii. p. 1001, t. 10. f. 9 (from an injured specimen), 1772.

Priapulus caudatus, Lamarck, An. s. Vert. lst. edit. tom. iii. p. 77,1816 ; 2nd edit. iii. p. 467, 1840; Schweigger, Handb. der Naturg. p. 554, 1820 ; Fleming, British Animals, p. 491, 1826; Blainville, Dict. Sc. Nat. art. Vers, tom. lvii. p. 554, 1828 ; Forbes, Hist. British Starfishes, p. 256, fig. annexed, 1841 ; M.-Edwards, Cuv. R. An. edit. Crochard, Zooph. t. 2l. f. 2 ; Frey and Leuckart, Beit. zur Kenntn. wirbellos. Thiere (anatom.), pp. 40-45, 1847; Sars, Mag. for Naturvidenskab. p. 76, 1850 ; Diesing, Syst. Helm. tom. ii. pp. 71 \& 556, 1851 ; Revis. der Rhyngod. l. c. p. 769, 1859; O. Schmidt, Zeitsch. für die gesammten Naturwissensch. Halle, 1854, p. 4 , t. 2. f. $4 a-b$; Maitland, Faun. Belgii Septent. tom. i. p. 96, 1851 ; Phillips, Report of British Assoc. 23rd meeting, at Hull, in 1853, Notices and Abstracts, pp. 70-71, 1854; Ehlers, Zeitsch. für wissenschaft. Zool. tom. xi. p. 209, t. 20. f. 1-13, t. 21. f. 14-22, 1862; Keferstein, Beitr. zur Anat. und Syst. Kennt. der Sipunculid. p. 208, 1865; Quatrefages, Hist. Nat. des Annel. tom. ii. part 2. p. 601,1865 .

Priapulus, sp., Cuvier, R. An. 2nd edit. tom. iii. p. 242, 1830.

Priapula caudata, Guérin, Iconog. R. Anim. Zooph. t. 5. f. 2, copied into Griffith's An. Kingd. tom. xii. Zooph. t. 12. f. 2, 1834 (both copied from Müller).

Priapulus hibernicus, M'Coy, Ann. \& Mag. Nat. Hist. 1st ser. tom. xv. p. 272, t. 16. f. 1, 1845 ; Diesing, Syst. Helm. ii. p. 71, 1851 ; Revis. Rhyng. l.c. p. 770, 1859.

Lacazia hibernica, Quatrefages, Hist. Nat. Annel. ii. p. 604, 1865.

$H a b$. Coasts of Greenland, Norway, Great Britain, and shores of German Ocean.

B.M.

This species, like most of the group to which it belongs, varies remarkably in appearance according as it is observed alive or, as it is generally seen, corrugated and preserved in spirits. Professor Forbes, in his ' History of the British Starfishes,' points this out, and says that when alive it will in a moment change its size from half an inch to as many as four or five inches. Professor Phillips, in his notes upon the animal seen alive, quoted above, says that it becomes very active in the sunshine, "drawing in and exserting the proboscis quickly and even suddenly, opening and again contracting the large caudal plume, bending, extending, and shortening the body without any settled order of changes." This will account for the discrepancy in the various figures given by different authors. The figure given by Müller in his ' Zoologia Danica,' copied into Guérin's 'Iconography,' and the works of Abildgaard \& Forbes would almost be sufficient, were 
it not for the author's descriptions, to induce one to suppose that they referred to a distinct species from the animal figured by Ehlers and others, and the specimens from Scotland and Greenland which we possess in our Collection. The $P$. hibernicus of M'Coy, as figured by him in the 'Annals,' exactly corresponds with the figure given by Ehlers of $P$. caudatus, and with our specimens of that species in the Collection as corrugated by the spirits in which they have been preserved. I have no hesitation, therefore, in referring it to our $\boldsymbol{P}$. caudatus. What Quatrefages could see in either M'Coy's description or figure to induce him to place it in the genus Lacazia I am at a loss to understand. Indeed he himself places it there with doubt. Linnæus, in his dissertation, 'Chinensia Lagerstrœmiana' (first published in 1754), and afterwardsin the 'Amœnitates Academicæ,' vol.iv. p. 255, and in the 10th edit. of the Syst. Natur. p. 656 (1758), describes a species of Priapulus which has been usually quoted as synonymous with the $P$. caudatus. He names it in these works Priapus humanus - an objectionable name in itself, and which he afterwards changed in the 12th edition of the 'Systema Naturæ' to Holothuria priapus. As the species of plants and animals mentioned in that dissertation ('Chinensia Lagerstrœmiana') chiefly refer tothose inhabiting the Southern or East-Indian and Chinese seas, and as in the 10th edit. of the Syst. Nat. he mentions distinctly the habitat " in mari indico," I have some hesitation in referring the species described there to the caudatus, which is a northern species, and not likely to be met with in the Indian seas. Osbeck, however, a pupil of Linnæus, mentions a species as found in China, and which is referred to the Holothuria priapus of Linnæus. His voyage to China was made in the years 1750-52; and an English translation, with a 'Faunula Chinesia' attached, was published in London in 1771: vide this edition, p. 337.

\section{Priapulus glandifer.}

Priapulus glandifer, Ehlers, Zeitschr. f. wissensch. Zool. tom. ii. p. 209, t. 20.f. 24, 1862 ; Quatrefages, l.c. p. $601,1865$.

Hub. North seas (Ehlers).

\section{Priapulus brevicaudatus.}

Priapulus brevicaudatus, Ehlers, l.c.t. 21. f. 23, 1862 ; Quatrefages, l.c. p. 601, 1865.

Hab. North seas (Ehlers).

\section{Priapulus tuberculato-spinosus. (Pl. XI. fig. 3.)}

Proboscis 25 costis longitudinalibus tuberculato-spinosis; cauda brevis, papillis numerosis validis longe acuminatis; dentes os cingentes, pallidi, in basi lati cum aculeo parum incurvato unico; corporis pars postica verrucis magnis obsita.

Hab. Falkland Islands. Collected by Dr. J. Robertson during the Antarctic expedition under the command of Sir James Ross. B.M. 
This species, according to the only specimen we have in the Collection, is upwards of five inches in length, and the trunk is about one inch in circumference. It is of an olive colour, the exsertile part of the body, or proboscis, darker than the rest of the animal. This proboscis is large, somewhat club-shaped; and the ribs, which run down longitudinally, are placed at some distance from each other, and, instead of being roughened with short spines (muricated) as in the other known species, are beset at nearly equal distances with unequal-sized small tubercles, which have a lax spine coming out of the centre. The lower extremity of the body is covered with rather large warts. The tail itself is short; but the papillæ which surround it are numerous, rather strong, and terminate in a long sharp point. The teeth (which surround the mouth) are of a pale colour, of tolerable size, spring from a broad base, and have only one (the central) spine, slightly curved inwards. The lateral small teeth, seen in the other species, in this one appear to be altogether wanting. The body is divided into numerous flattened rings, about fifty in number; the grooves or sulci which separate them are very distinct ; and each ring. is marked with a fine groove running round the centre; it is nearly smooth at the upper part, becoming striated as it descends, and is beset very sparingly with sharp spines, which, however, are most numerous posteriorly.

\section{Genus 2. Halicryptus*.}

Halicryptus, Siebold, 1849 ?; Diesing, 1859 ; Keferstein, 1865 ; Quatrefages, 1865.

\section{Halicryptus spinulosus.}

Halicryptus spinulosus, Siebold, in Neue Preussische ProvincialBlätter, vii. figs. 8, 9, 1849 ?; Diesing, Revis. der Rhyngod. in l.c. p. 779, 1859; Keferstein, Beitr. in Nach. kön. Gesellsch. Göttingen, p. 208, 1865; Quatrefages, l.c. ii. p. 599, 1865.

Hab. - ?

\section{Genus 3. Chetoderma.}

Chretoderma, Lovén, Hornschuch, Arch. Skandinav. 1845; Diesing, Revis. d. Rhyngod. 1859; Keferstein, Beitr. in l. $c$. 1865.

Chetoderma, Quatrefages, l.c. 1865.

\section{Chetoderma nitidulum.}

Chæetoderma nitidulum, Lovén, Hornschuch, Arch. Skandinav. Beitr. z. Naturg. i. p.69, tab., et in Froriep, Neue Notiz. tom. xxxiv. p. 26, f. 43, 1845 ; Diesing, Revis. der Rhyng. in l.c. p. 770, 1859; Keferstein, Beitr. in l. c. p. 208, 1865.

Chetoderma nitidulum, Quatrefages, l. c. ii. p. 602, 1865.

Hab. Coast of Sweden (Lovén).

* Diesing, followed by Quatrefages, places this genus amongst his "genera minus cognita;" but Keferstein accepts it as belonging to the family Priapulida. 


\section{? Genus 4. Lacazia.}

Lacazia, Quatrefages, l.c. 1865.

\section{LACAZIA LONGIROSTRIS.}

Quatrefages, l.c. ii. p. 603 , t. 20 (16 bis in textu). f. 18, 19, 1865.

\section{Hab. —?}

This appears to be a doubtful genus. Certainly the second species quoted by Quatrefages (Lacazia hibernica) is a true Priapulus, and is nothing more than the Priapulus caudatus ( $P$. hibernicus, M'Coy).

\section{Order II. GEPHYREA ARMATA.}

Rhynchelidea, Diesing, Syst. 1851.

Sipunculidea baseostomata, Diesing, Revis. 1859.

Gephyrea armata, Quatrefages, $l$. c. ii. 1865.

\section{Family I. Sternaspide.}

Sternaspidea, Quatrefages, l.c. ii. 1865 ; V. Carus.

Sternaspidida, Malmgren, Annulat. polychæt. Spitsberg. Grœnland. \&c. p. 85, 1867.

\section{Genus Sternaspis*.}

Sternaspis, Otto, Nov. Act. 1821 ; Blainville, Dict. Sc. Nat., 1828 ; Cuvier, R.A. 1830 ; Lamarck, A.s. V. 1838 ; Krohn, Müll. Archiv, 1842; Quatrefages, Hist. Nat. Annel.1865; Malmgren, l.c. 85, 1867. Echinorhynchus, sp., Renier, 1807.

Thalassema, sp., Ranzani, Isis, 1817 ; Schweigger, Handb., 1820 ; Martens, 1824.

\section{Sternaspis scutata.}

Mentula cucurbitacea marina, Janus Plancus, De Conchis minus notis, p. 110, t. 5. App. f. D, E, 1760.

Echinorhynchus scutatus, Renier, Tavola alfabetica delle Conchiglie Adriatiche, $1807+$ (as quoted by Ranzani in his paper in 'Isis').

Schreberus bremseri, Renier, Catalog. Vienn. (? MS.), 1807 ? fide Otto et Blainv.†

Thalassema scutatum, Ranzani, Isis, 1817; ib. xii. pp. 1457-60,

* M. Claparède, in his critique on the classification of the Annelida, especially with reference to that of M. Quatrefages, in the 'Bibliothèque Universelle,' 1867 , and translated in the 'Annals \& Magazine of Nat. Hist.' for November 1867, expresses his concurrence with Oken, Siebold, Max Müller, and Malmgren in their opinion that the genus Sternaspis belongs to the true Annelida. $\mathrm{He}$ also says that it is astonishing "that in the year $1865 \mathrm{M}$. de Quatrefages, in assigning to Sternaspis a place among the Gephyrea, should still mistake the head of these animals for the tail, without taking any notice of the beautiful anatomical investigations of MM. Krohn and Max Müller, and more especially as neither Bianchi (Janus Plancus), Ranzani, nor Delle Chiaje had fallen into the error of Oken and Otto, now corroborated by the authority of M. Quatrefages" (Ann. \& Mag. Nat. Hist. 1867, p. 361).

I retain here the genus Sternaspis amongst the Gephyrea, as, in outward form at least, it seems to be more nearly allied to this group than to the true Annelids.

+ These works I have not been able to see. 
t. 11. f. 10-14; Eysenhardt, Isis, 1818; ib. xii. p. 2086, t. 26. f. 1, 2 ; Schweigger, Handb. der Naturgesch. der ungeglied. Thiere, p. 593, 1820; Martens, Fauna Veneta, in Reise nach Venedig, Theil ii. p. 486, 1824.

Sternaspis thalassemoides, Otto, Epist. gratulator. Vratislav. $1820^{*}$, and in Nov. Act. Nat. Cur. t. x. pp. 619-27, t. 50. f. 1-5, 1821 ; Blainville, Dict. des Sc. Nat. art. Vers, p. 500, Atlas, t. 26. f. $1,1 a-1 d, 1828$; Delle Chiaje, Mem. Stor. e Notom. degli Animali del Reg. Napol. vol. iv. t. 62. f. 18, and (descript. of plate) p. 204, 1829 ; Cuvier, Règn. Animal, tom. iii. p. 245, 1830 ; Guérin, Icon. du Règn. An. Zoophytes, t. 6. f. 4 ; Cuvier, R. A. edit. Griffith, vol. xii. p. 456, t. (Zoophytes) 1. f. 3, copied from Guérin, 1834; Cuv. R. A. edit. Crochard, Echinod. p. 45, t. (Zoophytes) 22. f. 3, ? 1837 ; Lamarck, An. s. Vert. v. p. 535, 1838; Krohn, Müll. Archiv für Anat. 1842, p. 426 ; Max Müller, Obs. Anat. de Verm. quibusd. Marin. p. 1, tab. 1* (quoted by Quatrefages), 1852 ; Quatrefages, Hist. Nat. des Annelés, tom. ii. p. 391, 1865.

Sternaspis scutata, Malmgren, Annulat. polychæt. Spitsberg. \&c. p. $85,1867$.

Hab. Mediterranean and Adriatic seas.

B.M.

2. Sternaspis fossor, Stimpson.

3. Sternaspis affinis, Stimpson.

Sternaspis affinis, Proceed. Acad. Nat. Sc. Philadelphia, 1864, p. 159.

Hab. Puget Sound (Stimpson).

4. Sternaspis assimilis.

Sternaspis assimilis, Malmgren, l.c. p. 87, 1867.

$H a b$. West coast of France.

5. Sternaspis islandica.

Sternaspis islandica, Malmgren, l. c. p. 87, t. 14. f. 85 .

$H a b$. Iceland.

\section{Family II. Echiurida.}

Echiurea, Quatrefages.

Schizorhynchelidea (part.), Diesing.

Thalassema (part.), Cuvier.

Thalassamacea (part.), Forbes \& Goodsir.

Thalassemata (part.), Brandt.

\section{Genus Echiurus.}

Lumbricus, sp., Pallas, Fabricius, Gmelin.

Thalassema, Cuvier, Lamarck, Bosc, Blainville, Leach, Savigny, M. Edwards.

Echiurus, Cuvier, Règn. Animal, 2nd edit. tom. iii. p. 244 ; Guérin, Forbes, Brandt, Quatrefages, Diesing.

1. Echiurus vulgaris.

Lumbricus echiurus, Pallas, Spicil. Zool. fasc. x. p. 5, t. 1.

* Works not seen by me. 
f. 1-5, 1774; Miscell. Zool. p. 148, t. 11. f. 1-6, 1766; O. Fabricius, Faun. Grœnland. p. 285. no. 268, 1780; Gmelin, Syst. Natur. tom. i. p. 3085. no. 9, 1789 ; Bruguière, Encyc. Méthod. Helm. t. 35. f. 3-6.

Thalassema rupium, Lamarck, Syst. des An. sans Vert. p. 339 (synonyms excluded), 1801 *.

Thalassema echiurus, Bosc, Hist. des Vers, i. p. 224, t. 8. f. 2, 3, 1802 ; Cuvier, Bullet. des Scien. 18 ; Règn. An. lst edit. ii. p. 529,1817 ; Lamarck, An. s. Vert. 1st edit. v. p. 300, 1818 ; 2nd edit. v. p. 534, 1838; Schweigger, Handb. der Naturg. ungegl. Thiere, p. 593, 1820 ; Blainville, Dict. des Sc. Nat. art. Vers, p. 499, 1828 ; Mettenheimer, in Senckenbergische Abhandl. tom. i. Lief, 1.p. 6, t. 1 . f. 19 (cum anat.).

Thalassema vulgaris, Savigny, Syst. des Annélides, p. 102, 1809. Thalassema aquatica, Leach, Encyc. Brit. Supp. vol. i. p. 451, 1824. Echiurus, sp., Cuvier, Règn. An. iii. p. 244, 1830.

Echiurus pallasii, Guérin, Icon. Règn. Anim. Zoophytes, t. 6 . f. 3, copied into Griffith's An. Kingd. vol. xii. p. 456, t. (Zoophytes) 1. f. 3, 1833; Diesing, Rev. d. Rhyng. l.c. p. 775, 1859 ; Quatrefages, Hist. Nat. des Annelés, tom. ii, part 2. p. 592, 1865.

Thalassema neptuni, Edwards, Règn. An. edit. Crochard, Zooph. t. 21 . f. 4 .

Echiurus vulgaris, Forbes \& Goodsir, Ed. New Phil. Journ. xxx. p. 369 , t. 7. f. 1, 1841 ; Forbes, Brit. Starfishes, p. 263, f., 1841, copied into Froriep's N. Notiz. tom. xviii. no. 392, pp. 273-280, f. 11-23 (cum anat.), 1841 ; Sars, in Mag. for Naturvidensk. 1850, pp. $10 \& 17$; O. Schmidt, Zeitschrift f. d. gesammt. Naturwiss. 1854, Band iii. p. 6, t. 2. f. 5 .

$H a b$, Coasts of Belgium and Great Britain, W. sands, St. Andrew's (Dr. McIntosh).

B. M.

\section{Echiurus gaërtneri.}

Echiurus gartneri, Quatrefages, Ann. des Sc. Nat. 3rd series, t. vii. p. 307 , t. 6 (anatomy), 1847 ; Cuv. Règn. Anim. edit. Crochard, Zoophytes, t. 23. f. 1 ; Hist. Nat. des Annelés, tom. ii. part 2. p. 593, t. 16. f. 13, 1865; Voyage en Sicile, p. 221, t. 25, 26; V. Carus, Icon. Zootom. t. 8. f. 20 ; Diesing, Revis. der Rhyngod. p. 776,1859 .

$H a b$. St. Vaast, Normandy (Quatrefages).

\section{Echiurus forcipatus.}

Holothuria forcipata, Fabricius, Faun. Grœnland. p. 357, 1780. Echiurus forcipatus, Reinhardt, Naturhist. Bidr. Besk. Gröen-

* This species was named Thalassema mupium by Lamarck in 1801, but not described; and the references he gives to the figures of Pallas and the Encyc. Méthod. represent the Sipunculus edulis. Savigny was the next to name it, which he did by calling it Thalassema vulgaris. He describes it at some length (1809), and refers to the proper figures of Pallas \&c. I have therefore followed Forbes and Goodsir in preserving the specific name given it by this eminent naturalist. 
land, 1857 ; Diesing, Revis. Rhyng. p. 776, 1859 ; Quatrefages, Hist. Nat. Annelés, tom. ii. pt. 2. p. 593, 1865.

Bonellia fabricii, Diesing, Syst. Helm. ii. p. 75, 1851.

Hab. Greenland (Fabricius, Rudolphi, Rink).

4. Echiurus lutkenir.

Echiurus lutkenii, Diesing, Icon. Zoogr. Ferdinand. I. Imperator., Rev. der Rhyng. p. 777, 1859; Quatrefages, Hist. Nat. des Annelés, tom. ii. pt. 2. p. 593,1865 .

Hab. Helleboek (Liitken).

5. Echiurus sitchaensis.

Thalassema no. 1, Mertens, MS. in l.c. infra.

Echiurus sitchaënsis, Brandt, Prod. Desc. Anim. a Mertensio obs. fasc. i. p. 62, 1835; Lamarck, An. s. Vert. 2nd edit. tom. iii. p.472, 1838; Diesing, Rev. der Rhyngod. p. 777 ; Quatrefages, $l . c$. p. $593,1865$.

Hab. Sitka Sound (Mertens).

6. Echiurus caraibicus.

Echiurus caraibicus, Diesing, Icon. Zoogr. Ferdinand. I. Imperat., Rev. Rhyng. p. 777, 1859; Quatrefages, l.c. p. 594, 1865.

Hab. West Indies (Suenson et Krebs, fide Diesing).

\section{?7. Echiurus Chrysacanthophorus.}

Holothuria chrysacanthophora, Couthoy, fide Diesing.

Echiurus chrysacanthophorus, Pourtalès, Proc. Amer. Ass. Ad. Sc. v. Meet. 1851, p. 39; Diesing, l.c. p. 778, 1859 ; Quatrefages, Hist. Nat. Ann. tom. ii. part 2. p. 594, 1865.

Hab. North-American Sea.

? 8. Echiurus chilensis.

Echiurus chilensis, Max Müller, Obs. Anat. de Verm. quibusd. Marit. p. 21, 1852; Diesing, Revis. l. c. p. 778, 1859; Qnatrefages, l.c. p. 594, 1865 .

$H a b$. Coast of Chili.

\section{Fam. III. Bonellide.}

Bonelliea, Lacaze, Quatrefages.

Schizorhynchelidea (part.), Diesing.

\section{Genus 1. Thalassema.}

Thalassema, Gärtner, Cuvier, Forbes, M.-Edwards, Farran, Quatrefages, Diesing.

Lumbricus, sp., Pallas, Gmelin.

Thalassina, Montagu.

Ochetostomum, Leuckart et Rüppell, Diesing.

Holothuria, sp., Lesson.

1. Thalassema neptuni.

Thalassema neptuni, Gärtner in lit., Pallas, Spic. Zool. tom. i. 
fascic. 10. p. 8, 1774; Cuvier, Règn. Anim. tom. iii. p. 244, 1830 ; Guérin, Icon. R. Anim. Zoophytes, t. 6. f. 2, copied into Griffith's An. Kingd. tom. xii. p. 456, Zoophytes, t. 1. f. 2, 1833; Lamarck, An. s. Vert. 2nd edit. tom. iii. p. 472, 1846 ; Forbes \& Goodsir, Edinb. New Philos. Journ. tom. xxx. p. 370, 1841, and in Froriep's Neue Notiz. tom. xviii. p. 273, 1841; Forbes, Brit. Starfishes, p. 259, fig. append., 1841 ; Farran, Ann. \& Mag. Nat. Hist. 2nd series, tom. vii. p. 156, 1851 ; Nat. Hist. Review, tom. vi. p. 70, 1859 ; Diesing, Revis. der Rhyngod.l.c. p. 772, 1859; Quatrefages, Hist. Nat. Annelés, tom. ii. pt. 2. p. 594.

Lumbricus thalassema, Pallas, Spic. Zool. tom. i. fasc. 10. p. 8, t. 1. f. 6, 1774; Gmelin, Syst. Nat. p. 3085. no. 10, 1789 (synon. prim. excluso); ? Turton, Linn. Syst. Nat. tom. iv. p. 59; Brit. Fauna, p. 125, 1807 (synon. prim. excluso), descriptions and references copied from Gmelin.

Thalassina mutatoria, Montagu, Linn. Trans. vol. xi. p. 24, t. 5. f. 2,1815 .

Thalassema mutatorium, Cuvier, Règn. Anim. tom. iii. p. 244, 1830 ; Edwards, Règn. Anim. edit. Crochard, Zoophytes, t. 21. f. 4,5 .

Ochetostomum Gartneri, Diesing, Syst. Helminth. tom. ii. p. 73. no. 3 , and p. 550 , 1851 .

Ochetostoma mutatorium, Diesing, l.c. no. 4.

Hab. Coast of England, Devonshire (Montagu); Cornwall (Cocks, Laughrin, \&c.); Ireland, near Dungarvon (Farran). $\quad$ B.M.

2. Thalassema brevipalpis.

Thalassema brevipalpis, Quatrefages, Hist. des Annel. tom. ii. pt. 2. p. 595, 1865 .

Hab. —?

\section{Thalassema peronir.}

Thalassema peronii, Quatrefages, l. c. p. 595, 1865.

$\mathrm{Hab}$. Indian seas.

\section{Thalassema lessonir.}

Holothuria eaouari, Lesson, Cent. Zool. p. 91, t. 31. f. 2, 1830 ; Guérin, Icon. R. An. Zooph. t. 4. f. 6 (copied from Lesson).

Ochetostomum lessoni, Diesing, Syst. Helminth. ii. p. 73, 1851.

Thalassema lessonii, Diesing, Revis. d. Rhyng. l.c. p. 774, 1859; Quatrefages, $l . c$. ii. p. 596, 1865.

Hab. Borabora, Oceania (Lesson).

\section{Thalassema gigas.}

Thalassema gigas, Max Müller, Obs. Anat. de Verm. quibusd. Marit. p. 14, t. 3. f. 1-12, 1852 ; Diesing, Revis. d. Rhyngod. $l$. $c$. p. 773,1859 ; Quatrefages, $l . c$. ii. p. 596, 1865.

Hab. Coast of Italy (Max Müller).

\section{Thalassema grohmanni.}

Ochetostomum grohmanni, Diesing, Syst. Helm. ii. p. 74, 1851. 
Thalassema grohmanni, Diesing, Revis. der Rhyngod. p. 773, 1859 ; Quatrefages l.c. p. 596, 1865.

Hab. Sea at Palermo (Grohmann).

\section{Thalassema pelzelnir.}

Thalassema pelzelnii, Diesing, Icon. Zoogr. Ferdinand. I. Imperat.; Revis. d. Rhyng. l. c. p. 774, 1859; Quatrefages, l.c. ii. p. 596, 1865 .

Hab. West Indies (Diesing).

8. Thalassema erythrogrammon.

Ochetostoma erythrogrammon, Leuckart \& Rüppell, Atlas z. Reise im nördl. Afric. Zoophytes, p. 7, t. 2. f. 3, 1828.

Ochetostomum erythrogrammon, Diesing, Syst. Helm. ii. p. 72, 1851.

Thalassema erythrogrammon, Max Müller, Obs. Anat. Verm. Marit. p. 16, 1852 ; Joh. Müller, Müll. Arch. 1854, p. 97 ; Diesing, Revis. d. Rhyng. l.c. p. 774, 1859 ; Quatrefages, l.c. ii. p. 599, 1865.

Hab. Red Sea (Rüppell).

\section{Genus 2. Bonellia.}

Bonellia, Rolando, Cuvier, Blainville, Edwards, Schmarda, Lacaze Duthiers, Diesing, Quatrefages, \&c.

\section{Bonellia viridis.}

Bonellia viridis, Rolando, Mem. d. Reale Ac. d. Sc. di Torino, tom. xxvi. pp. 539-556, t. 14. f. 1-3, t. 15. f. 5-7, 1822 ; Isis, 1823, pp. 398-403, t. 5 ; Blainville, Dict. Sc. Nat. art. Vers, p. 576, Atlas, t. 38. f. 1, $1 a-1 d, 1828$ (copied from Rolando); Cuvier, Règn. Anim. 2nd edit. tom. iii. p. 244, 1830 ; Dujardin, in Lamk. A. s. Vert. 2nd edit. tom. iii. p. 47l, 1840 ; ? Guérin, Icon. Zooph. t. 6. f. 1; Edwards, Règn. An. edit. Crochard, t. 21. f. 3, ? 1840; Diesing, Syst. Helminth. ii. p. 74, 1851 ; Revis. Rhyngod. p. 771, 1859 ; Schmarda, Denkschrift. der Ak. der Wiss. in Wien, tom. iv. pp. 117-126, t. 4-7, 1852 ; Ersted, in Kröy. Tidss. tom. iv. p. 579; Lacaze Duthiers, Ann. Sc. Nat. 4th ser. tom. x. pp. 49, 110, t. 1. f. 1, 2, t. 2 (anatomy), 1858; Quatrefages, Hist. Annelés, tom. ii. pt. 2. p. 597,1865 .

Hab. Mediterranean (Rolando).

\section{Bonellia fuliginosa.}

Bonellia fuliginosa, Rolando, l.c.p. 552, t. 15. f. 4, 1822; Dujardin, in Lamk. A. s. Vert. 2nd ed, tom. iii. p. 471 ; Diesing, Syst. Helm. p. 75,1851 ; Revis. d. Rhyng. p. 771,1859 ; Quatrefages, $l$. $c$. p. 598,1865 .

Bonellia viridis juvenilis, Blainville, Dict. Sc. Nat. tom.lvii. p. 576 , Atlas, Apodes, t. 1. $b, 1828$ (fide Diesing).

Hab. Coast of Sardinia (Rolando).

Proc. Zool. Soc.-1868, No. VIII. 


\section{EXPLANATION OF THE PLATES.}

\section{Plate IX.}

Fig. 1. Sipunculus angasii, Baird, nat. size, p. 80 .

2. - deformis, Baird, nat. size, p. 80.

3. Phascolosoma capsiforme, Baird, nat. size, p. 83 .

\section{Plate X.}

Fig. 1. Pseudaspidosiphon gracile, Baird, magnified, p. 103.

$1^{\text {a }}$. The same, nat. size, p. 103.

2. Phascolosoma perlucens, Baird, magnified, p.90.

$2^{\text {a }}$. The same, nat. size, p. 90.

3. Themiste lageniformis, Baird, magnified, p. 98.

$3^{\text {a }}$. The same, nat. size, p. 98.

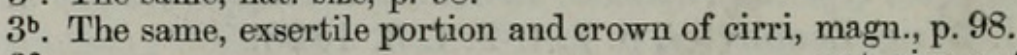

$3^{\mathrm{c}}$, " , " , nat. size, p. 98 .

\section{Plate XI.}

Fig. 1. Phascolosoma nigriceps, Baird, magnified, p. 90.

$1^{\mathrm{a}}$. The same, nat. size, p. 90 .

2. Aspidosiphon cumingii, Baird, nat. size, p. 102.

3. Priapulus tuberculato-spinosus, Baird, nat. size, p. 106.

3. Notes on the Breeding of several Species of Birds in the Society's Gardens during the year 1867. By A. D. Bartlett, Superintendent of the Society's Gardens.

\section{(Plate XII.)}

The following list of species of birds bred during the last year will be found to contain several that I believe have never been before recorded as having reproduced in the Society's Gardens; and some of the facts noted are of considerable importance with reference to the habits and affinities of the species to which they belong:-

Impeyan Pheasant.

Rufous Tinamou*.

Pallas' Eared Pheasant*.

Japanese Pheasant.

Common Cassowary*.

Barred-tailed Pheasant*.

Cheer Pheasant.

Swinhoe's Pheasant*.

Lineated Pheasant.

Purple Kaleege.

Black-backed Kaleege.

Bankiva Jungle-fowl.

Talegalla.

Sun-Bittern (Eurypyga).

Black Kite*.

Black-crested Cardinal*.

Turquoisine Parrakeet.

Dusky Duck.

Bahama Duck.

Carolina Duck.

Ruddy Sheldrake.

New Zealand Sheldrake.

Ruddy-headed Goose.

Ashy-headed Goose.

The most remarkable of these is perhaps the Rufous Tinamou (Rhynchotis rufescens), of which species I am able to state that the male bird incubates, and that one male will attend to two or more

* Those marked thus have bred for the first time. 


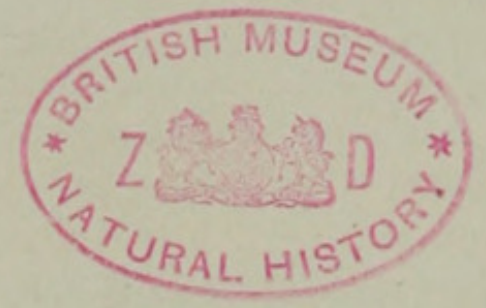


females*. The number of eggs laid by two birds between the 20th of May and the 24th of September was eighty-five; out of this number, upwards of twenty birds were hatched. Many more would have been hatched had it not been for the parent birds, who were guilty of frequently eating the eggs before the young birds had arrived at a perfect state. It was only by removing the eggs to the care of common hens that we succeeded in hatching and rearing sixteen or eighteen young birds.

The male bird would take to the eggs when ten or twelve were laid, and after about fifteen days' incubation was found breaking them up and eating the contents, which in many instances were imperfectly developed young. In no instance did the female attempt to incubate. The period of incubation was twenty-one days. The chick (Pl. XII. fig. 1) much resembles the young of a Rhea, and, from its small size, looks and walks about like a little Apteryx; in fact the keepers and others who saw Tinamous for the first time thought they were the young of the former bird. They fed upon worms, chopped meat, boiled eggs, \&c.

Of the several species above mentioned some have bred in the gardens many times; but as a few of them have bred for the first time, I beg leave to call particular attention to these.

Perhaps the most valuable addition to the list is the breeding of the Barred-tailed Pheasant (Phasianus reevesii). It is mostremarkable that the birds arrived on the 22nd of June and commenced laying immediately, and four birds were hatched on the 10th of August. Another singular instance of late breeding occurred with a fine pair of imported Versicolor Pheasants, which arrived from Japan on the 27th of July, and three young birds were produced on the 20th of September. These birds were considered useless and not likely to live; but two of them (hens) are now strong and healthy birds, having perfectly got over their moult during the coldest part of this winter.

Of the Crossoptilon or Eared Pheasant of Pailas we have reared nine fine birds, the second hatch, having lost by the gapes the first brood of seven. With reference to this species, I may remark that these birds breed when only one year old. At the first moult the young birds assume the adult plumage, the male and female being exactly alike. They are remarkably hardy, and extremely tame.

In concluding, I beg to call attention to my paper published in the Society's 'Proceedings' for 1862, on the habits and affinities of the Kagu (Rhinochetus jubatus). I there gave it as my opinion that this bird was more nearly allied to Eurypyga than to any other bird. Again, in the Society's 'Proceedings' in January 1866, at pp. 77 and 78 , I stated, after speaking of the egg and young bird :-

"That Eurypyga is less a Heron than has generally been thought must now be admitted, and the spotted egg and downy young one abundantly shows. I feel, however, certain that this bird has its nearest ally in the Kagu (Rhinochetus jubatus), as already stated (see P. Z. S. 1862, p. 218)." Having stated this so long since, it is

* The eggs are laid on the ground in a hollow formed by the male bird in the sand or mould. No other nest is made. 
with great pleasure I have this evening to offer a most striking proof of the correctness of these views, one of the Kagus at the Gardens having had the kindness to lay a very fine egg, which I now place before you. (See Plate XII. fig. 3.) This egg was rendered useless for hatching immediately after it was laid, by being pecked by the bird that laid it, or by some other bird in the aviary. It is, however, a very fine and well-marked specimen, and in many particulars closely resembles the egg of Eurypyga (Pl. XII. fig. 4), but perhaps exhibits rather more of the form of the eggs of the Cranes (Grus) than of the Rails and Plovers. Moreover the lively movements of the bird as described by me in 1862 fully support its affinities with the Cranes, and show, I think, that it has less affinity to the Ardeine group.

\section{DESCRIPTION OF PLATE XII.}

Fig. 1. Chick of Rhynchotis rufescens.

2. Egg of Rhynchotis rufescens.

3. Egg of Rhinochetus jubatus.

4. Egg of Eurypyga helias.

4. Additional Notes on the Ornithology of the Pelew Islands. By Dr. G. Hartlaub and O. Finsch*

A new collection from the Pelew Islands has been submitted to our examination. This collection was formed by the late Dr. Semper of Altona, and is now deposited in the Museum of that town. It consists of eighteen species, two of which are undescribed :-

1. Collocalia vanicorensis, Q. \& G.

The only difference between this oceanic species and $C$. francica from the Mascarene Islands consists in the colour of the under tailcoverts, which are of a simple brown colour in C. vanicorensis, of a much darker and bronze-glossed hue in C. francica.

2. Halcyon sanctus, Vig. \& H.

Two younger birds, not different from Australian specimens.

3. Myzomela rubratra, Less.

4. Psamathia anne, Hartl. P. Z. S. 1868, p. 5, t. iI.

Av. jun. Supra magis brunnescens, subtus magis in fulvum vergens; subalaribus albo flavoque mixtis; flexura ala fava.

5. Artamus leucorhynchus, Gm.

Lanius manillensis, Briss. ii. p. 180, t. 18. f. 2. (descr. opt.) ; Buff. Pl. Enl. 9. fig. 1; Lath. Syn. i. p. 181.

Pie-grièche dominicaine, Sonn. Voy. Nouv. Guin. p. 55, t. 26.

Lanius dominicanus, Gm. S. N. p. 307.

Leptopterus melaleucus, Wagl. Syst. Av. (excl. synon.); Kittl. Küpfert. t. 30. fig. 1 ; Hahn, Vög. Ausl. Lief . 19. t. 2. (fig. bon.). The fact is that there are two species of Artamus on the Philip-

* See above, p. 4. 
pines, and more especially on the island of Luzon. One is the old Brissonian Lanius manillensis, figured also by Sonnerat. This is the larger species, black above and white below. It is very certainly this species that is also found on the Pelew Islands.

The other is the well-known Javan species, a somewhat smaller bird with the upper parts of a more or less greyish or purplish brown. We have examined many specimens from the island of Luzon, where it appears to be more common than A. leucorhynchus. The oldest name for this species is Art. leucorhynchus, Horsf. (nec Gmelin!); and it is Art. leucogaster of Valenciennes.

6. Zosterops Semperi, n. sp., Hartl.

Supra olivaceo-flavescens, annulo periophthalmico albo; lineola a naribus ad oculum ducta et toto gastrao citrino-favis; subalaribus albis, flavo variegatis; remigibus fuscis, dorsi colore limbatis; hypochondriis parum olivascente adumbratis; rostro dilute brunneo, mandibula pallidiore; pedibus plumbeis.

Long. $4^{\prime \prime}$, rostr. $4 \frac{1}{2}{ }^{\prime \prime \prime}$, al. $2^{\prime \prime} 1^{\prime \prime \prime}$, caud. $15^{\prime \prime \prime}$, tars. $8^{\prime \prime \prime}$.

7. Rhipidura lepida, Hartl.

8. Myiagra erythrops, Hartl.

Both not different from the former specimens.

9. Tephras finschir, Hartl. P. Z. S. 1868 , p. 6 , t. vi.

One adult specimen, in which the wings are more complete than in the type specimen of M. Godeffroy's collection. There is a conspicuous first spurious quill as in the Sylviadæ (4"' long). The fourth and fifth quills are the longest and of equal length; the third and sixth are a little shorter; the second is of equal length with the seventh. In the type specimen the first spurious quill was wanting.

10. Calornis kittlitzir, nob.

11. Charadrius fulvus, $\mathrm{Gm}$.

12. Charadrius geoffroyi, Wagl.

13. Charadrius cantianus, Lath.

Exactly like a Heligoland specimen in winter dress.

14. Rallus pectoralis, Less.

\section{Porphyrio melanotus, Temm.}

A smaller race of the well-known Australian bird. The largest of four specimens from the Pelews is still considerably smaller than the smallest of the Australian specimens of $P$. melanotus in the Leyden collection. The measurements of the very small specimen of this collection are :-Long. tot. circa $15^{\prime \prime}$, rostr. a rict. $1^{\prime \prime} 3^{\prime \prime \prime}$, al. $7^{\prime \prime} 10^{\prime \prime \prime}$, caud. $2^{\prime \prime} 10^{\prime \prime \prime}$, tars. $2^{\prime \prime} 9^{\prime \prime \prime}$.

16. Nycticorax caledonicus, Gml. 
17. Ardea sacra, Gml.

Three young birds in different states of plumage. In one of these the white colour is interrupted by brown longitudinal spots at the end of the scapulars and wing-coverts. Another is of a dirty olive-brown, intermixed with slate-coloured plumes, and with an indistinct white chin-stripe.

18. Gygis alba (Sparrm.).

We add a list of the 41 known species of birds of the Pelew Islands.

1. Collocalia vanicorensis.

2. Halcyon sanctus.

3. - albicilla.

4. - reichenbachii.

5. Myzomela rubratra.

*6. Psamathia anna.

*7. Tephras finschi.

*8. Zosterops semperi.

*9. Rhipidura lepida.

*10. Myiagra erythrops.

*11. Rectes tenebrosus.

12. Artamus leucorhynchus.

13. Calornis kittlitzii.

*14. Ptilonopus pelewensis.

15. Carpophaga pacifica.

*16. Megapodius senex.

17. Rallina fasciata.

18. Rallus pectoralis.

19. Ortygometra quadristrigata.

20. Porphyrio melanotus.
21. Numenius phropus.

22. Actitis hypoleucus.

23. Tringa minuta.

24. - acuninata.

25. Strepsilas interpres.

26. Charadrius fulvus.

27. geoffroyi.

28. cantianus.

29. Ardea sacra.

30. Nycticorax caledonicus.

31. goisagi.

32. Anas superciliosa.

33. Fuligula cristata.

34. Puffinus opisthomelas.

35. Sterna lunata.

36. Gygis alba.

37. Anous stolidus.

38. Phaëton candidus.

39. Dysporus piscator.

40. sula.

41. Carbo melanoleucus.

[The eight species marked with an* are exclusively proper to the Pelew group.]

5. Observations on Dr. Gray's "Notes on the Arrangement of Sponges, with the Description of some New Genera." By J. S. Bowerbank, LL.D., F.R.S., F.Z.S., \&c.

Previously to criticising the arrangement of the Spongiadæ proposed by Dr. Gray, it would perhaps be as well to take a rapid review of the principles of arrangement adopted by previous writers on the subject, and of the system originally proposed by me in papers on the anatomy and physiology of the Spongiadæ in the 'Philosophical Transactions' for 1857 , p. 279 , 1858, p. 747 , and 1862, p. 1087, and also in my 'Monograph of the British Spongiadæ,' published by the Ray Society for the years 1864 and 1866 .

Previous writers on the Spongiadæ have, with very few exceptions, 
all adopted the system of division and subdivision of these numerous and protean animals by means of their chemical constituents and their external forms ; and the results of their attempts at classification by such means have universally been unsuccessful in leading students to a ready recognition, or, indeed, to scarcely any recognition at all, of the species described by the authors who have had recourse to such systems. The natural result has been that every naturalist who has attempted to recognize the species of his predecessors has found himself to so great an extent unsuccessful, through the vagueness and uncertainty of the system that was to have been his guide, that he has therefore naturally commenced his career of the study and record of species unknown to him by a new method of arrangement, which, although perhaps sufficient for his own limited circle of subjects, becomes, when applied to a fresh series of them, quite as inapplicable to a general and extended view of these singularly protean forms as those of his predecessors.

This was precisely the condition in which I found myself at the commencement of my own career of investigation; and I naturally asked myself the question, Is there no means of escape from these various and inefficient modes of registering the examination of these animals, through a natural division of them into classes, orders, and genera, by means of their internal and external organization, after the manner pursued in other departments of zoology, and especially in botany? Strongly impressed with this idea, I commenced an investigation of a large collection of British and foreign species in my own possession ; and I soon found that sponges, like other organized beings, were always provided with a skeleton, and that, as in other branches of zoology, the materials and mode of its structure varied very considerably in different species, and that those peculiarities of its structure were remarkably uniform and persistent through a considerable number of species in which they occurred. Here, then, was a foundation for the primary division of these creatures, in perfect accordance with the rules of zoological science as established by Linnæus, Cuvier, and other laborious and talented authors of modern times; and I had the satisfaction of finding that the more widely I extended my observations the more nniform and certainly available these primary parts of the organization became; and in addition to their characters of uniformity and constancy, there was this strong recommendation of them as bases for the foundation of classes, orders, and genera, that, however imperfect in form or dilapidated by external injuries or partial decomposition, the most persistent and last surviving part of the animal was always the skeleton.

In botany and some branches of zoology the principal difficulty that meets the student is the correct determination of the genera; but this is not the case to so great an extent in the study of the Spongiadæ when their characters are founded on their structure and organization. As far as the genera have been established on these principles, they are so well marked, both by the material and the peculiar modes of the arrangement of their component parts, that they 
are certainly recognized by the aid of the microscope with greater decision and facility than those of many other branches of zoology or of botany.

Having thus assigned the skeleton to the determination of genera, it became a question as to what parts of the organization were the most appropriate to the distinction of the species. Hore, again, the lucid example of the great father of systematical botany, Linnæus, naturally suggested the most advisable course of proceeding; and the example that he set botanists in a rigid examination and a compendious nomenclature of those parts of the plant that were rather auxiliary and only occasional in their presence, and not absolutely necessary to the existence of a plant, naturally suggested the course to be pursued with regard to the determination of the species among the Spongiadæ; and first amidst these characters stood forth the spicula, the fit compeers of the leaves of plants in their great variety of form; and, like them, they are as widely distributed and as completely without reference to generic peculiarities. Other subsidiary organs in the sponges have also their value as specific characters, and have been thus applied accordingly; but among these form and colour, the sheet anchors of the old modes of arrangement, are undoubtedly of the least value, from the perfectly protean character of the first, and the variable and evanescent peculiarities of the latter. My first task, therefore, was to acquaint myself, as completely as I possibly could, with the various normal forms, and their varieties, of the spicula and their especial situations and peculiar offices in the animal economy. In aid of this object, I accumulated a vast number of specimens from various quarters of the world; and as each peculiar form of spiculum became known to me I had to record and distinguish it by a name, as I found no such thing as a systematic description or nomenclature of the organisms of the Spongiadæ existing. How far I may have executed this task to the satisfaction of the scientific world I must leave time to decide, and, where necessary, to correct. In thus attempting to establish a nomenclature of parts hitherto undescribed, I have endeavoured to make these terms expressive of the forms and qualities of the organs in the same manner as the designations of leaves more or less describe their forms and the modes of their arrangement. But this one thing is certain, that without a definite nomenclature no descriptive science can hope to progress with any degree of precision or success.

My first application of the nomenclature thus formed was originally published in the 'Philosophical Transactions,' as I have before stated; and it has been applied to the British species of sponges in my monograph of them published by the Ray Society.

This work, Dr. Gray is of opinion, is not sufficiently distinct and definite in its descriptions to answer the required purpose; and he seeks to remedy this defect by his proposed new mode of arrangement, which is based principally on the forms and peculiarities of the spicula, totally ignoring the skeleton as a means of arrangement into orders or genera.

It would require almost a volume to discuss and expose the fallacy 
of the whole of the numerous vague and extraordinary alterations in the existing systematic arrangements of the Spongiadæ proposed by him with a degree of hasty inconsideration that has led him into errors of omission and commission too numerous to be mentioned in detail ; I will not, therefore, attempt a minute critical examination of his new system of arrangement, but content myself with pointing out the prominent errors and inconsistencies of his plan. Thus, in page 493, he writes :- "The division between the calcareous and siliceous sponges is very distinct and natural; the separation between the siliceous and keratose sponges, on the other hand, is very indistinct and separates nearly allied genera." But he does not state what are the nature of these alliances; nor does he seem to consider that the alliance must really be closer between sponges having spicula with calcareous or siliceous bases than between either and those having no spicula at all. And he then enumerates a series of distinctive characters belonging to the Spongiadæ that are, upon the showing of his own descriptions of them, amply sufficient to establish each as a separate order or genus; and having done this, he concludes the paragraph thus:- "I believe it better to unite the siliceous and keratose sponges of these zoologists into one group or order." $\mathrm{He}$ then discusses the skeleton-spicula in the same loose manner, thus:"The spicula that form the main part of the skeleton of these siliceous sponges are of three shapes:-

"Fusiform (acerate, Bowerb.), more or less cylindrical, and pointed at each end. Needle-shaped (acuate, Bowerb.), cylindrical, blunt at one and sharp at the other end. Pin-shaped (spinulate, Bowerb.), cylindrical, with a more or less spherical head and a tapering point," totally omitting to mention the true cylindrical form, plate 1. fig. 12, ' Monograph of British Sponges,' and entirely ignoring the first three primary forms of acerate, acuate, and spinulate, neither of which are fusiform in their typical forms, the fusiformity and the attenuation being merely secondary characters, or variations of the typical forms, and applicable alike to the whole four of them.

The author then describes the whole of the auxiliary spicula of sponges in the same loose and hasty style. He writes-"The stellate are usually scattered in the sarcode; and the three-pronged are what Dr. Bowerbank calls tension and defensive spicula." This is quite incorrect as regards the "three-pronged" spicula, as I have never designated them as tension spicula, but always as defensive ones. He then proceeds thus- "The forms of the spicules are characteristic of the different families, if they are not always peculiar to them. Thus the many-rayed stellate, with rays on all sides, and the three-pronged or three-hooked elongate spicules are characteristic of the Geodiada and Tethyada. The anchorate and birotulate spicules and other forms of the series are almost peculiar to the family Esperiada." These assumptions of Dr. Gray are also, to a great extent, erroneous. In the first place, I totally deny that " the forms of the spicules are characteristic of the different families." On the contrary, the primary skeleton forms are common to all of them; the spicula are not characteristic even to a genus; and in 
many cases all the four forms occur in different divisions of the same genus; and in some individuals, as in Isodictya varians (Mon. Brit. Spongiadæ, vol. ii. p. 281), as many as three of the primary forms occur mixed in the skeleton; and in Isodictya infundibuliformis (Mon. Brit. Spong. vol. ii. p. 317) we have the spicula of the primary lines of the skeleton attenuato-acuate, while those of the secondary lines are acerate, and in many other species we find acerate prevailing in number, but with a considerable admixture of acuate forms, thus totally ignoring the assumptions of Dr. Gray that the forms of the spicula are characteristic of the different families. Neither are " the many-rayed stellate, with rays on all sides, and the three-pronged or three-hooked elongate spicules characteristic of the Geodiadae and Tethyada." Thus the sphero-stellate form occurs abundantly in Dictyocylindrus stuposus (Mon. Brit. Spongiadæ, vol. ii. p. 116) and in many exotic species in no degree allied to either Geodia or Tethea, and ternate or "three-pronged" spicula are an essential part of the structure in some species of Dactylocalyx and other exotic genera. These are not the only crude and inaccurate assertions regarding the general structural characters of the spicula of sponges that are made by the author, but they are sufficient to illustrate the hasty style in which he arrives at his conclusions on these subjects.

Page 499. Dr. Gray states the object of his proposed new system thus :- "I would propose the following arrangement as bringing together the species which seem most allied, and also as facilitating the study of these very difficult and anomalous animals." The author's generalizations in constructing his system are upon a wonderfully expansive scale. Thus his subclass Porifera silicea, p. 502, will include at least 99 per cent. of the whole number of known sponges, the calcareous ones as compared with the others being exceedingly few in number.

The first step the author takes in his endeavours to simplify the arrangement of-the sponges is to merge in one subclass the two very distinct divisions of Dr. Grant of Silicee and Keratosa ; and the unfortunate result is immediately visible in the same and following pages, 503 and 504, in bringing together groups the species of which are of the most varied and opposite anatomical structure; and the difficulty is increased by the author's descriptions of his orders immediately following, which are so vague and loosely put together as to be nearly incomprehensible, even to naturalists well acquainted with sponges.

The first difficulty occurs in his description of section 1, page 502, "Malacospora(Soft-spored Sponges). Reproduction by ova contained in a thin membranaceous ovisac not strengthened by siliceous spicules or by gemmules scattered in the substance of the sponge." The author does not seem to be aware that it is comparatively a rare occurrence to find the description of gemmules to which he refers in situ, as they only occur thus at certain periods, and then for only a short time; so that in thus making them the sole character of his section 1, Malacospora, he is placing a complete stumblingblock in 
the way of the student, who would naturally conclude they were organs always present in the sponge, while, in fact, he may search for them in many dozen specimens of Halichondria panicea and other allied species without once seeing a gemmule in situ.

If we may judge of the extent of their distribution by their ascertained presence in various genera, and by the negative evidence afforded by our knowledge of other descriptions of ovaria, it will not be an overestimate if we believe that they will be found in at least 95 or 96 per cent. of the known siliceous and keratose sponges.

Page 502, subsection 1. "Netted sponges (Dictyospongia). Skeleton formed of a continuous siliceous or horny network." This definition embraces so wide a range and such varied modes of structure that it is calculated rather to bewilder the student than to facilitate his researches. It would include rather more than 75 per cent. of the whole number of the British sponges, and also the whole of the author's second, third, and fourth orders, excepting his Tethyada.

Subsection 2, p. 503. The families included in this section, if distributed in accordance with its wording, might just as correctly be referred to subsection 1 , page 502 , as to order 4 , p. 504 , section 2. Chlamydospore is founded on a misapprehension of the structure of the spicula of the ovaria, which have no defensive characters, but are simply portions of the wall of the ovarium, which is so constructed that the spicula may allow of a slight degree of lateral expansion of that body; their external surfaces in the adult state are flat coincident planes. The sponges having truly armed ovaria or gemmules are entirely excluded by the author from this section, the family Tethyadae being disposed of in his order 4, Acanthospongia, p. 504 .

In truth, the confusion of ideas existing in the descriptions of these orders is such as to render it perfectly impossible to comprehend the characters by which species are to be referred to any one or the other of them.

This course of proceeding is not divisional arrangement; it is no separation of the multitudes with the members of which we want to cultivate an individual acquaintance. These vague expansive ideas are not definitive or distinctive. What we want in such descriptions is a certain group of characters within a definite circle to be readily separated from other well-defined groups or circles by which they are surrounded, such as we see amidst the natural orders of plants, and not a flow of indefinite verbosity, that leaves us in a labyrinth of words, amidst an impervious cloud of ideas.

\section{The Orders.}

The author's orders are seven in number. They are formed principally by an elevation of his own and other writers' genera to that dignified position in science, their characters being constructed by a free version of their previous generic ones; but in many instances these alterations or additions have a very unfortunate result, as they have led to serious errors of description. 
In his " 1 st order, p. 502, Coralliospongia. Sponges hard, coral-like, entirely formed of siliceous spicules anchylosed together by siliceous matter into a network. Mass covered by a thin coat of sarcode when alive." This description is eminently incorrect. No one, I believe, ever yet saw the terminations of spicula united into a network through the morbid action of anchylosis by means of siliceous matter. The material by which they are naturally cemented together is keratode. The author does not seem to be aware that, although sponge-fibres always anastomose more or less, sponge-spicula never do so. And in the description of bis first family in this order, Dactylocalycida, page 505, the author distinctly abnegates his own definition of the order by describing the family thus :- "This beautiful family of sponges is at once known by having the skeleton formed of continuous anastomosing fibres formed of concentric lamina of silica, forming a hard brittle network."

Order II. Keratospongia, p. 503. In his definition of this order, the author takes an extremely wide range of skeleton-structure, embracing the true sponges, Dysidea, Chalina, Phakellia, and other genera differing widely in their structural peculiarities.

"Subsection 2. Spicular Sponges (Spiculospongia), p. 503. Sponge fleshy, more or less strengthened by fasciculated or scattered siliceous spicules, the bundles being sometimes slightly covered with a thin layer of horny matter. The sarcode is generally abundant; in some few, as Euplectella, it is thin, mucilaginous, and deciduous."” This description is decidedly incorrect as regards Euplectella, Owen, as that sponge assuredly has a siliceo-fibrous skeleton, and not a spiculo-fibrous one. See Proc. Znol. Soc. 1867, p. 361 .

" Order III. Leiospongia. Sponge-spicules of only one kind, often varying in size and shape in the same species." This is another exceedingly vague description on which to found an order; and we may reasonably ask whether, if they vary in shape, they can be of only one kind. There are very few species in which the spicules, strictly speaking, would be only of one kind, and in every spiculoreticulate sponge they are liable to variations in size and shape. The author has placed three families in his version of this order, but in the illustration of each of them he violates his own rules. Thus, in his list of illustrative species of Halichondria (p. 519), he includes $H$. farinaria and distorta, both of which have two forms of spicula.

The same error occurs in his family Polymastida,-Polymastia bulbosa and radiosa each having two forms, and $P$. robusta three forms of spicula.

The like error is also apparent in his family Clionida, as, according to Mr. Hancock's description of exotic and other species of Cliona, several of them have at least two forms of spicula in their structure.

Order IV. Acanthospongia. This is a most expansive order, as it would embrace every siliceo-spiculous family excepting those included in the author's order 3. The Euplectelladae are erroneously placed in this order. 
I have before stated, in treating of subsection 2, that Euplectella, Owen, is not a spiculo-reticulate sponge, but truly a siliceo-fibrous one ; but under the head of Dr. Gray's order 4 it will take its place very well, as among its auxiliary spicula it certainly has " spicules of more than one form or kind." This, however, is rather a loose way of disposing of it, and totally ignores the most essential part of its structure, the skeleton.

Order V. Arenospongia is formed by the conversion of the author's genus Xenospongia into an order. The specimen is in the British Museum, and is described in the Proc. Zool. Soc. for 1858, p. 320.

Section II. p. 504. Chlamydospore. What the author means by "sponges with armed spores" it is difficult to imagine, unless it be meant to intimate that sponges are vegetable bodies; but as he combines the term spore with that of ovisac, it is probably only an error in his terminology; and this is very likely to be the case, as in order VI. Spharospongia, immediately following, he describes the "ovisac" as emitting ova. The ovaria or "ovisacs" are occasionally armed or constructed with spicula; but the ova, or spores, have never yet been found to contain them.

Order VI. Spharospongia. Both of the author's families Geodiada and Placospongiada are misplaced in this order, as the ovaries or "ovisacs," as I have before stated, are in neither case armed, the external surfaces of the adult bodies being perfectly smooth in every species with which I am acquainted.

Order VII. (p. 504) is based on the structural peculiarities of the ovaria of the genus Spongilla ; but, from the author's vague descriptions of their structures, both "Tethya" and Geodia would be as naturally referred to this order as to order 6 .

\section{The Families.}

The families comprised in the seven orders are eighteen in number; they are simply based on the genera established in the works of Dr. O. Schmidt, the 'Monograph of British Spongiadæ,' and a few other authors, including those of Dr. Gray, the characters of the genera being taken by the author and generally altered in the manner of description, but certainly not with the effect of rendering them more definitive or distinctive. I will not discuss their merits seriatim, but notice those only in which the errors are of a striking character.

Family 1. Dactylocalycida, p. 502. In consequence of the inaccuracy of the description of order I. Coralliospongia, which is stated to be "entirely formed of siliceous spicula anchylosed together," the family the members of which are siliceo-fibrous, and not spicular, in their skeleton-structures, appears to be entirely misplaced. The author's description of his order should therefore be amended to remedy this discrepancy, or the family removed to another order.

Family 7. Ophistospongiada, p. 503. This term is an error in spelling, as it is derived from my genus Ophlitaspongia, Mon. Brit. Sponges, vol. ii. p. 14. 
Family 8. Phakelliada. The author, in endeavouring to vary the mode in which I have described the genus Phakellia, states that the "skeleton is formed of closely reticulated horny fibres, forming an expanded mass," \&c. This is incorrect, as it is not a kerato-fibrous sponge, but belongs to the order Silicea. See Mon. Brit. Sponges, vol. i. p. 186.

Family 10. Polymastiada, p. 503. "Sponge with tubular fistulous branches; tubes open at the end, and formed of longitudinal and transverse fascicules of fibres."

Here, again, the author has fallen into a great error in describing the "fistulous branches" as open at the end. In no species of Polymastia that I have ever seen is that the case. See Mon. Brit. Sponges, vol. ii. p. 73.

Family 12. Euplectellada, p. 504. "Skeleton composed of longitudinal, transverse, and oblique bundles of spicules intersecting each other, and forming a network." This description of the structure of the skeleton of Euplectella, Owen, as I have before stated, is incorrect, the whole skeleton being truly siliceo-fibrous.

Fanily 13. Esperiada, p. 504. "Sponge massive. Skeleton composed of fusiform and linear spicules, interspersed with anchorate, bihamate, or birotulate spicules. Sarcode soft."

The description of this family is singularly incomprehensible. "Sponge massive." This character would apply to by far the greater number of sponges in existence. "Skeleton composed of fusiform and linear spicules." All the four primary forms of skeletonspicula are liable to fusiformity; which of the four forms does the author mean, any one in particular or all of them? And when he names "linear," what form of linear spiculum does he mean? as all straight or slightly curved spicula are linear. "Interspersed with anchorate, bihamate, or birotulate spicules." This embraces a most extensive field of investigation, as we shall presently see. "Sarcode soft." All sponge-sarcode is soft. Thus it will be seen that every one of the characters assigned by Dr. Gray to the Esperiada are singularly indefinite. Subsequently, at page 532, he divides the family into six sections, which are about as ill-defined as the characters of the family. In the first place, the author designates all the retentive spicula as defensive spicula. The defensive spicula, external and internal, are quite another class of spicula than those peculiar to the sarcode. See Mon. Brit. Spong. vol. i. p. 21.

The application of the retentive, or bihamate and anchorate, spicula to the distinction of families or genera is peculiarly unfortunate. I will not trace their occurrence through the exotic genera of sponges, but confine myself to their range among the British genera. They are met with in Microciona, Hymedesmia, Hymeniacidon, Halichondria, Isodictya, and Desmacidon - six genera, containing 126 species; and of this number of species, 51 only have their spicula imbedded in their sarcode; and it rarely occurs that a species has only one form, and frequently three forms are present mixed together.

Family 14. Tethyada, p. 504. The author describes the ske- 
leton in this family as " consisting of simple filiform spicules, with three prongs or three recurved points at the outer end." This is inaccurate. The skeleton of Tethea cranium, Johnston, which the author has selected as the type of his family, is composed of simple fusiformi-acerate spicula, the fusiformi-porrecto-ternate and fusiformi-recurvo-ternate ones being purely external defensive spicula (Mon. Brit. Spon. vol. ii. p. 83).

\section{The Genera.}

Having discussed the general principles of Dr. Gray's new systematical arrangement of the sponges in his classes, orders, and families, we will now proceed to consider the mode in which he proposes to establish his numerous new genera; and it will perhaps facilitate our comprehension of his scheme if we first consider the present condition and numbers of the genera in contrast with the characters and numbers of Dr. Gray's new series of them.

The author proceeds in the first place to adopt to a considerable extent the genera established by previous writers on the Spongiadæ, altering the phraseology according to his own ideas of terminology, sometimes omitting, as in his character of Stematumenia (p. 5l1), the most distinctive character of the genus, the fibro-membranous tissues, and then adding a variety of characters derived from the specific ones of the type species of the genus he adopts, thus completing the heterogeneous mixture of descriptions. In this mode the author has adopted sixteen genera from Professor O. Schmidt's 'Die Spongien des Adriatischen Meeres,' twenty-nine from my 'Monograph of the British Sponges,' and seven others from various authors, making a total of fifty-two genera. The number of genera treated of in Dr. Gray's paper is 157 , so that we have a total of 105 new genera proposed to be established; and these, we shall find, are based upon the descriptions of species hitherto comprised in the genera of the authors quoted above, with alterations to suit the occasion. And, finally, others are founded on the descriptions of single spicula, described in the anatomical portion of vol. i. of my 'Monograph of British Spongiadæ' as examples of organic form, without the slightest knowledge on his own part of the sponges whence they were derived.

In the construction of his families, we have seen that the course pursued by Dr. Gray has been that of appropriating every known genus within his reach, without the slightest consideration of the different and perhaps discrepant principles on which they have been based by their respective authors. The same mode is adopted by him in his proposed new genera.

Every species having a determinate specific character is at once seized upon by Dr. Gray, and converted into a new genus; and it seems to matter little to him whether the specimen the characters of which are thus appropriated be in his own possession or the property of a private collector, as, in the latter case, it is surreptitiously taken, withont the least regard to the owner of the specimen, or 
the slightest notice of his intended appropriation of it. Numerous cases of this description occur in his "Notes on the Arrangement of Sponges ;" and I cannot give a better instance of it than that of his genus Astrostoma, p. 514.

As an example of the facility and inaccuracy with which Dr. Gray propounds a new genus, in part 1 of the Proceedings of the Zoological Society for 1867 , in his paper on Zoanthina, in treating of Palythoa, p. 238, hewrites thus:- "Mr. Bowerbank, in his 'British Sponges' (t. 20. fig. 307), figures a very similar body, which he describes as a portion of the dermal surface of an undescribed sponge from the East Indies, having numerous depressed pores, furnished with stomata, like protective organs. Mr. Tyler, F.L.S., has kindly shown me some specimens of the sponge mounted as a transparent and an opake object; and they are very like a parasitic actinoid polype; but the rays are strengthened with spicules on the surface, and on the tips with some prominent ones (which form a pencil), unlike any Actinia $\mathrm{I}$ have seen, and so they are perhaps sponges. If so, they ought to form a genus, which may be called Astrostoma." Such a mention of a microscopic fragment would certainly never be considered a fit characterization of a new genus; and yet, in his paper on Sponges, part 2 of the Proceedings of the Zool. Soc. for 1867 , p. 514, it is quoted thus :- "Astrostoma, Gray, P. Z. S. 1867, p. 239." He now proceeds to characterize his new genus as follows :- " 9. Astrostoma. Sponge solitary, branched ; fibres horny, flexible. Oscules? circular, scattered and concave, sunk in the surface, with eight or ten rays, which are covered with spicules. Spicules small, subulate, in corneous fibre." He subsequently writes, "I have been enabled, through Mr. Tyler, to examine the original specimens from which Dr. Bowerbank described this species, which is probably a parasite like the genus Bergia of Michelotti."

In every one of these details he is completely wrong. In the first place, what he means by "solitary," as a generic character, I really cannot comprehend; secondly, it is not branched. It is a simple unbranched cylinder, nine inches in length, and three-fourths of an inch in diameter for a considerable portion of its length. Thirdly, it has not a particle of keratose fibre in its structure, being purely spiculo-reticulate; and it is quite inflexible. The author then describes the inhalant areas as oscules, and does not mention the true oscula, although two out of twenty-one of them are figured in a portion of this sponge (Mon. Brit. Sponges, vol.i. plate 20. fig. 308), and are described, along with the inhalant areas, in page 278 of the same work; and lastly, the spicula are not subulate, nor are they " in corneous fibre." Thus there is not a single point in the descriptive character of the author's genus Astrostoma that is correct. Nor is Dr. Gray correct in stating that he has " been enabled, through Mr. Tyler, to examine the original specimens from which Dr. Bowerbank described the species," as the original specimen has never been out of my hands, Mr. Tyler having only received from me a small piece from which to mount microscopical specimens. The specimen figured in vol. i. Mon. Brit. Sponges, plate 20. fig. 307, 
has never been out of my possession. We may naturally ask what confidence can we place in the system of an author who is so systematically incorrect?

In this style Dr. Gray has described sixty-five sponges in my possession which he has never seen; and of these sixty-five, fifty are the types of a portion of his new genera. The consequences of this mode of proceeding are that he has fallen into some most extraordinary errors. I will not weary my readers by specifying and criticising all the author's efforts of this description; the first one in his list, extracted from the 'Monograph of British Sponges,' will suffice for the purpose. Page 533.-“3. AEgogropila. Sponge massive or coating, rugose. Oscules large, dispersed. Skin spiculose. Skeleton reticulated; fibres formed of bungled spicules. Spicules of four kinds :- -1 . Fusiform, needle-like, or subclavate. 2. contorted and reversed, bihamate. 3. Inequianchorate, bidentate. 4. Fusiform, tricurvate."

If this generic character be compared with the specific character of Desmacidon agagropila, Mon. Brit. Sponges, vol. ii. p. 352, it will be at once seen to be almost verbatim the same, with the exception of a new generic character of the author's own invention, that of "bungled spicules," the meaning of which I must leave to the reader's own imagination. There is also an alteration in the name of the author's new genus, which is printed AEgogropila in place of Egagropila, the original specific name of Dr. Johnston, sufficiently applicable to the species, but not so as a generic name.

Similar distortions of established generic and specific names occur in several other instances. Thus, in page 507 of his paper, for Farrea orca, we should read $F$. occa; pages 503 and 515 , for Ophistospongia read Ophlitaspongia ; page 545, 20. Vibulinus, for var. damicenus read damicornis; page 534, Iophon, for bipolicated read bipocillated; page 527, 2. Polymastica read Polymastia; page 527, 1. Pencillaria, $S$. pencillus should be $S$. penicillus; page 542 , 7. for Eciomemia read Ecionemia ; page 532, synopsis of sections of Family II., bi- or tripolicated should be bipocillated; there is no such form as tripocillated. Other errors of the same description occur dispersed through the work; but these will serve to display the loose and careless style in which the author has treated his subject.

But these are not the most extraordinary efforts of the author; for in one case he has not only made two new genera and two new species out of one species, but out of one individual of that species, and without having seen the sponge or even the slip of glass containing the spicula from which he derives his two new genera. $\mathrm{He}$ bases his new genus Dymnus, page 539. no. 27, on the figures of spicula represented in my work on British Sponges, vol. i. pl. 5 . figs. $115-117$, and his genus Damo, page 539 , no. 28 , on the spicula represented by figures $118-120$ in the same plate, not being aware that both forms are contained in the same slide of spongespicula, which was prepared from a small fragment of a sponge from

Proc. Zool. Soc.-1868, No. IX. 
Sicily by Mr. Topping and was presented to me by him. Now the question arises, which of these new genera and species are to stand? are either or neither? Common sense would answer, the latter. One would naturally imagine that this facility in creating genera could not be carried to a more absurd extreme; but, strange as it may appear, under the ingenious manipulation of Dr. Gray, that is really the case, as in page 544, the genera and species, 14. Acarnus innominatus, and 15. Fonteia anomala are actually founded on one form of spiculum hitherto only found on one undescribed species of sponge. Acarnus innominatus is derived from fig. 292, pl. 18, 'Mon. Brit. Sponges,' representing a portion of the reticulated skeleton of the sponge with the radiating fasciculi of spinulo-quaternate internal defensive spicula in situ; while Fonteia anomala is based on the figures $73-76, \mathrm{pl} .3$, of the same work, representing the various stages of development of the same spinulo-quaternate spicula as those represented in situ in pl. 18, and which various forms are described by me in page 239, 'Mon. Brit. Spongiadæ,' as different stages of development of the perfect form represented by fig. 76 , and the reader is referred to pl. 18. fig. 92, in the same description, for a view of them in situ. Comment on such a case as this is superfluous; and, strange though it be, the author, with their descriptions before his eyes, describes them as "spicules of four kinds." If the author should steadily pursue the course described in the last cases we may ultimately arrive at the unforeseen and rather extraordinary conclusion that not only may single species represent a genus, but an individual may really be composed of a group of genera and species.

I will now endeavour to show the mischievous consequences, to closely allied and well-established genera, arising from Dr. Gray's mode of founding his new genera on peculiarities of form in the various auxiliary spicula of sponges, which are only present in certain species, and which vary more or less in form, combinations, and mode of disposition in almost every species in which they are found, instead of basing his generic characters on the more substantial and enduring characters afforded by the anatomical peculiarities of the skeleton. I will not comment on every instance in which his mode of proceeding has been highly detrimental to our power of discriminating species, but I will select a few only of the most illustrative ones. Thus in the genera Tethea and Geodia we have two of the most natural and most accordant groups of species among the whole of the Spongiadæ, groups which all naturalists have hitherto concurred in preserving entire. Let us see how the author proposes to treat them.

In the first place, Dr. Gray, in page 543 of his paper, misquotes both Dr. Johnston's ' History of British Sponges,' page 85 (or, more correctly, 83), and my 'Monograph of British Spongiadæ,' vol. ii. page 83, making us each to have adopted the term Tethya, whereas both have rejected that name and adopted Lamarck's name Tethea, for the very good reasons given by Dr. Johnston in page 83 of his work. Dr. Gray separates Johnston's two species T. cranium and T. lyncurium, leaving the former as the type of his Tethya, page 543, 
having previously disposed of the latter as Donatia aurantium, page 541 , in accordance with the views of Nardo. My two species, Mon. Brit. Spon. vol. ii. pp. $87 \& 89$, are converted into Collingsias; and Tethea muricata, of which he knows nothing, but the form of one sort of retentive spiculum, he transforms into Thenea muricata. Tethea robusta and $T$. ingalli, of which he knows nothing but the figures of a spiculum of each represented by figures $164 \& 165$, plate 6 . vol. i. Mon. Brit. Spon., he at once consigns to the rejected genus $C y$ donium, Fleming, resuscitated by Dr. Gray to be thus filled by his fertile imagination with species.

Dr. Gray thus disperses the species of one of the most striking genera with which we are acquainted among sponges-so much so that the student who has become acquainted with one species can scarcely fail at the first glance to assign any others he may acquire to their proper genus in existing arrangements.

The author has arranged the Geodiada in his Order VI. Spharospongia, page 547. In the definition of this order he has two names for the same organ in one sentence. In place of ovarium he has first ovisac-cells and then ova-cells ; and in his description of the family Geodiade, immediately following, there is a third variation, ovisacs.

Instead of placing the type genus of the family, Geodia, Lamarck, first, he gives that position to my genus Pachymatisma, decidedly an aberrant one, and places Geodia second. He then separates all the species of Geodia described by Prof. O. Schmidt and by me, and places them under the very doubtful genus $C y$ donium, Fleming, page 548, thus - "2. Cydonium muelleri [mülleri], Fleming, B. A. 516," in which Dr. Fleming describes his genus as having "polypi with a central opening and an orifice at the base of each of the eight pinnated tentacula,"-showing either that he had greatly mistaken the nature of Geodia zetlandica, Johnston, or that he had described the orange-coloured variety of Alcyonium digitatum, Johnston's 'British Zoophytes,' 2nd ed. vol. i. p. 174. The latter appears to be the most probable.

Dr. Gray then, to increase the confusion, adds to the genus $C y$ donium Tethea ingalli and T. robusta, from the figures of spicula only from each quoted by me in 'Monograph of British Spongiadæ,' vol. i. pl. 6. figs. $164 \& 165$, leaving Lamarck's genus Geodia to be represented by the type species, G. gibberosa, and one other, G. caribea, Duchass. et Michel. I have had the opportunity of carefully examining Lamarck's type specimen in the Jardin des Plantes, Paris, and am well acquainted with its organic structure; and I will veuture to say that no practical naturalist who has had the like advantage and was acquainted with the other well-known species of Geodia would for one moment dream of separating them from Lamarck's genus. To complete the confusion of ideas, we then have a specimen of Pachymatisma, P. listeri, on the faith of the form of one spiculum, figs. $50 \& 51$, pl. 2, Mon. Brit. Spong., transformed into a new genus, Triate, page 549 of the author's paper, and, by the same uncertain means, identified with Prof. O. Schmidt's Stelletta 
discophora. Dr. Gray, in page 549, “4 . Erylus," also introduces us to a new form of ovarium thus, "with oblong ovisacs ;" but I presume the author means oval ovisacs, not with flat sides and rectangular ends as in an oblong figure.

Dr. Gray's genus Placospongia, page 549, described by him in Proc. Zool. Soc. for 1867, p. 128, is neither more nor less than Geodia carinata, Phil. Trans. 1858, p. 314, tab. 36. fig. 42. Many years since, I found specimens of this species arranged in the cases at the British Museum among the corals, and I pointed them out to Dr. Baird as placed there in error ; and he immediately removed them from the case. I have several specimens based on Oculina rosea from the South Seas, and their history in MS. The species is structurally in perfect accordance with the genus Geodia, although very discrepant in external form from the majority of the other species of that rather numerous genus. The 18th family in Dr. Gray's proposed arrangement is Potamospongia, containing the Spongillidæ, which he treats in his accustomed style, dividing this eminently natural genus into seven divisions and adding to them as an eighth one my genus Diplodemia, a sponge of very different organization, the skeleton having an abundance of kerato-fibrous structure in its composition.

Page 557. Fam. 2. Alcyoncellida. Dr. Gray describes the genus Alcyoncellum thus-" Sponge soft, subgelatinous, slightly branched.

"Alcyoncellum et Alcyoncella, Blainville, Man. d'Actin. p. 529, 1832 (not Milne-Edwards, 1835, Bowerbank, nor Owen, Nardo, nor O. Schmidt).

"Alcyoncellum gelatinosum, Blainv. Man. d'Actin. p. 529, tab. 92. fig, 5."

" $\mathrm{Hab}$. -

B.M.?"

From this quotation we should naturally imagine that all preceding writers who have referred to this genus, as founded by MM. Quoy et Gaimard, were wrong; and that it was originally established by Blainville in his Man. d'Actin., published 1834, instead of by MM. Quoy et Gaimard in their ' Zoology of the Voyage of the Astrolabe,' published in 1830 , and that Dr. Gray was the only writer who had attributed the genus to its true founder, M. de Blainville. But on reference to the work of that author, we find that he makes the following observations regarding it in page 529 :-

"Observ.-Ce genre a été établi par MM. Quoy et Gaimard pour un corps organisé, rapporté dans leur dernier voyage, et qu'ils ont bien voulu soumettre à notre observation," \&c. After this, what are we to say to the correctness of Dr. Gray's quotations, and to the laws of nomenclature he would fain establish by his sole declaration? In such matters, and on such authority, are we to submit to his saying, "I am Sir Oracle; and when I ope my lips, let no dog bark"? or are we, in accordance with the excellent and just rules recommended by the committee for nomenclature of the British Association, to render justice to those authors by the permanent adoption of the names they have given to genera and species, which they have been the first to make known to science? 
That MM. Quoy and Gaimard did not correctly comprehend the nature and structure of their species, $A$. speciosum, is no reason why the name they assigned to it should be put on one side, and that of Euplectella, founded on error by Professor Owen, substituted for it. Or if this want of knowledge of a type specimen be sufficient to abrogate the author's title, then Dr. Gray's genus Aphrocallistes, described in Proc. Zool. Soc. 1858, p. 114, as a calcareous sponge, when in reality it is a siliceo-fibrous one, must fall by the same law.

If M. de Blainville has chosen his specimen to illustrate the genus Alcyoncellum injudiciously in his 'Manuel d'Actinologie,' that is no reason for abrogating the name originally assigned to their genus by MM. Quoy and Gaimard in their previously published work descriptive of the zoology of the voyage of the Astrolabe; and there can be no mistake as to which specimen is really the type of the genus, as they have figured it in the atlas to that work, plate 26 , Zoophytes, fig. 3.

Dr. Gray's second subclass, Porifera calcarea, is treated in the same unscrupulous manner, the only species left to represent Grantia being G. ciliata. Grantia ensata is turned into Ute ensata ; Grantia compressa into Artynes compressa. Leucosolenia, Leuconia, and Lucogypsia fare better, as they escape alteration.

If the course of proceeding adopted by Dr. Gray in the construction of his proposed new arrangement of the sponges is to be considered legitimate, if it be tolerated that any naturalist shall get sight surreptitiously of the specimens belonging to another, and then describe, name, and publish them, as in the case of his genus Astrostoma, page 514, unknown to the owner, and without permission so to use them, if it be considered right that from the figure of a single spiculum of a sponge, published in illustration of organic structural peculiarities by one author, any one has a right to name generically and specifically the specimen whence it is derived and without having ever seen it, and thus to forestall, haphazard, the manuscript descriptions of the owner of the specimens, nothing for the future will be easier than to establish new genera and construct new systems of arrangement; but then the question will naturally arise, of what use are such systems to practical naturalists? This question Dr. Gray himself answers in page 495 of his paper, in treating of Nardo's 'Spongiariorum Classificatio,' where he observes, "Almost all the species mentioned as belonging to the genera are new and not described in this paper; so that it is impossible to determine what they are except for such persons as have specimens named by the author." This observation of Dr. Gray respecting Nardo's species is perfectly correct; but the Doctor does not seem to be aware that it applies quite as justly to the genera and species which he has named in his own paper, without having seen the sponges whence his names are derived. I will not comment especially on the author's choice of generic names, as he has bespoken our indulgence on that subject at page 500 ; but they strongly remind me of an oral tradition among the old officers of the natural-history department of the British Museum, that in bygone days one of the principals of 
that department kept an old hat by him in which a large number of single letters cut out of old catalogues were stored, and that when he wanted a name for a new genus he used to dip his hand therein and take out a pinch of letters, which were scattered before him, and out of which, by a few judicious changes of arrangement, he formed the required name. From the nature of a number of the names of the new genera proposed by Dr. Gray in his arrangement of the sponges, it would appear highly probable that he has found the old hat and its contents in some one of the out-of-the-way corners in his department, and again applied it to its original use.

There are certain animadversions in the author's paper on my own course of proceeding in treating on the sponges both British and foreign, to which I must beg leave to say a few words in reply.

Dr. Gray complains (p. 496) of my not having referred to any of the exotic sponges described by him in the 'Proceedings of the Zoological Society,' and of my not having described the sponges in the British Museum. I have carefully gone over all the British species in that collection, and have referred to them, when necessary, in my 'Monograph of British Sponges' (as, for instance, vol. ii. pp. $275,277,279,281,364$, and elsewhere), and I should have described the sponges which Dr. Gray has written upon with pleasure had he requested me to do so. But all these specimens were described and named by him first and shown to me afterwards, and when I found he was thus skimming the cream of the subject I determined not to accept the leavings. I will not now point out the numerous errors regarding these species into which Dr. Gray has fallen, as it is very probable that $I$ shall have to recur to their descriptions at a future period.

Dr. Gray (p. 500) objects to the large number of species of British Sponges in my genera Halichondria, Hymedesmia, and Isodictya. Had I applied Halichondria as Dr. Johnston and previous writers had established it, instead of having 28 species of that genus in my ' Monograph of the British Spongiadre' there would have been 169 species. The number thus designated in Dr. Johnston's 'History of British Sponges' is 37. The Doctor's objection to the large number of species in the genera he names is plausible; but it is Nature and not I that am answerable for this difficulty; but in stating this objection he does not mention that the species of each of these genera are subdivided, by means of the various forms of the primary skeleton-spicula, into four or five divisions each, and that the greatest number of species in one group is 28 in the genus Isodictya. The author even extends his objection to my genus Dictyocylindrus, in which there are 11 species, and these subdivided into 4 groups, the largest of which contains 5 species. 'The learned author quite forgets that the same inevitable difficulty occurs in botany. In the fourth edition of Babington's 'Manual of British Botany,' we find there are 19 species of Roses, 32 of Salix, 33 of Hieracium, 41 of Rubus, and 72 of Carex. In all these cases the difficulty is very much lessened by judicious subdivisions of the respective genera. The author also objects to my terminology; but without a definite 
name for every part of a sponge we should no more progress successfully in the description of sponge-species than botanists would without their copious and well-considered descriptive language. Now I will venture to say that when the terminology relating to the parts of sponges applied in my 'Monograph of British Spongiadæ' has become familiar to the student, he will find no more difficulty in the recognition of a species of sponge described by means of the appropriate technicalities than a botanist encounters when he works out a species of plant that is new to him; and this is precisely the point at which I have aimed in my sponge-terminology, and by means of which I have described our British species of those animals. I am quite free to acknowledge that in the description of the sponges we are as yet but on the threshold of our structure, and that many new genera must be established to receive the amazing number of exotic species that are still undescribed; and the most that I can hope for in the course of study that I have shadowed forth in my 'Monograph of the British Spongiadæ' is, that it may prove a sound and useful foundation for the labours of future naturalists in this comparatively untrodden path of zoological science. I shall always hail with pleasure the appearance of new students of these extraordinary creatures, whose labours would advance our knowledge of their structural peculiarities and extraordinary habits ; but amongst this class of students I cannot recognize the author of the singularly loose and impracticable attempt at a systematic arrangement of them published in the Society's 'Proceedings' for May 1867.

The essential object of all systematic arrangements is that of arriving with facility and certainty at the knowledge of species by characters common to all the individuals of such groups. This end is not attainable among the Spongiadæ by external characters : age, size, colour, and locality modify the external appearances of these animals to so great an extent as to scarcely ever allow of two individuals presenting the same amount of characteristic similarity that is so prevalent among other species of animals. We are therefore driven by necessity to the internal organization to attain the great end of accurate recognition in defiance of all their protean variations in form and colour.

An accurate and extensive knowledge of species should therefore be our first step towards a scientific arrangement of such animals. As the number of species known to us increases, we quickly find that many of them agree in possessing certain structural characters in common, while each of them has some especial organ which is not existent in the others, and this single peculiarity determines the species; or it may be that the determinative points may be more than one, or that in place of organs peculiar to certain species, the character may be stamped by other modifications, such as comparative size and peculiar modes of association or disposition of organs common to many species. In any of these cases the development of these characters is uniform and certain during all stages of the growth of the individual, and, notwithstanding all other intervening difficulties, the discrimination of the species is effective and final. 
The nature of these characters is not that of organisms indispensably necessary to the existence of a sponge, but rather of those of an auxiliary description, which one species may require while another may well dispense with them.

As our knowledge of species extends, we quickly find that there are groups existing among them marked by peculiar modifications of the more essential organs of the sponge, such as those of the various modes of arrangement of the mechanical structure of the skeleton, while the material of which it is formed remains the same through a considerable number of such groups. Thus we arrive by a natural process at generic groups, which are on this constructive anatomical system quite as natural as species. Hitherto we have had but few well-defined genera of this description; and these few have been, as it were, thrust upon us by the irresistible evidence of Nature herself. Contrary to the received opinion of many able naturalists, I firmly believe that genera are quite as natural as species, and that it only requires perseverance on our own parts to recognize them, and to define their boundaries with accuracy and certainty. Of course we must expect cases occasionally to arise in which they approach each other by such insensible degrees as to render it extremely difficult to distinguish between the approximating points; but this appears also to be the case in botany, and in other branches of natural history, and may be considered the exception and not the rule of nature. Having thus established a natural foundation to our system of genera, the next step is that of classification; and here the material of which the skeleton is formed becomes a most important point of consideration. We find in the higher classes in zoology the animals of the highest degrees of organization secreting phosphate of lime as the basis of the skeleton; and as we descend in the scale of creation, the phosphate is replaced by carbonate of lime, and the skeleton becomes external instead of internal; the next step downward, and we lose the earthy material, and the keratode skeleton supplies its place; membrane succeeds to keratode; and finally all these substances are wanting, and sarcode becomes the entire animal. But amidst all these changes we find no class of animals secreting silex as the basis of its skeleton; this material is reserved as the great distinguishing character of the class Protozoa.

Among the Spongiadæ we observe a natural simulation, as it were, of this gradational retrogression of organization. None of them secrete phosphate of lime; but the highest organized species secrete carbonate of lime in abundance. The next gradation is the secretion of silex in place of lime, the silex being the predominant material of the skeleton; and to this tribe belong by far the greater number of existing sponges. Then follows an intermediate stage, similar to that of the cartilaginous fishes, where we find the cartilage the predominant material, with included floating or dispersed portions of earthy basis; so in the sponges, as in Chalina and other genera, we have keratode the essential portion of the skeleton, with siliceous spicula immersed in the fibres to give additional strength and substance to the structures ; and, finally, the skeleton becomes pure keratode, without 
any admixture of earthy material. In the mature state I do not believe that there is any species that is destitute of keratode and composed of sarcode only. I have never yet seen such a sponge; but in the young and earliest stages of the development of many species we have them, as in Spongilla and others, simply existing as moving masses of sarcode, which I believe have been designated by observers as AmœLa. In every specimen that $\mathrm{I}$ have yet seen that has been designated Halisarca I have always succeeded, by the aid of Canada balsam, in detecting minute siliceous spicula in situ. As regards the animal or vegetable nature of sponges, I may observe that in our investigations of this subject we must take a broader view than that of the ultimate structures of the animal. It is not a cell or a cilium that will decide that question. Nature is not so widely various in her general plan of operations as the world is prone to imagine. The tree, with its almost unlimited capabilities of propagation by seeds, by roots, or by cuttings, and in some cases even by single leaves, is the fit type of the coral, with its innumerable polypes, in each of which the germ of a separate animal is inherent. So it is with the sponge; each morsel of it is the germ of a separate existence; but the combined compound existences within it is in reality the animal. It is a congeries of existences in one. Not that the uniflagellate cells are to be designated as the animal; they are only vital points within, as seeds, buds, or axillary bulbs in plants. The late eminent Surgeon Liston on one occasion invited me to see the ciliated cells from a polypus in the nose of a patient at University Hospital ; but no one in such a case would dream of designating man as a congeries of polyciliated cellular animalcula. Such bodies are more or less incidental to the structure of almost all animals; and in the sponges the living organized mass is the animal, not its incidental parts, as some authors would seem to imply. A knowledge of the structure and offices of such organs in its economy is an important point in the history of the sponge; but it is the combined structures and working together of the whole organized mass that we must look to for the determination of its character, either as an animal or a vegetable ; and in the performance of its vital functions we have perhaps the most positive and undeniable evidence of its truly animal nature. Its nutrition is, like that of animals, voluntary and at intervals. It imbibes its food through one set of orifices, digests that which it has received, and excretes the rejected matter by appropriate oscula, while in plants these vital operations are involuntary and continuous.

\section{List of Birds collected at Conchitas, Argentine Republic, by Mr. William H. Hudson. By P. L. Sclater, M.A., Ph.D., F.R.S., and Osbert Salvin, F.Z.S.}

The authorities of the Smithsonian Institution, Washington, United States, America, have most kindly sent over for our inspection a series of birdskins collected at Conchitas, in the Argentine Re- 
public, about twelve miles from the city of Buenos Ayres, by one of their correspondents, $\mathrm{Mr}$. William $\mathrm{H}$. Hudson. We have had great pleasure in determining the species, a list of which is herewith given. Nearly the whole of them are included in the list of the birds of the Argentine Republic given in the second volume of Burmeister's excellent 'Reise durch die La-Plata-Staaten ;' but there are many points which call for remarks.

The following is a complete list of the species. The nomenclature used is generally that of Sclater's 'American Catalogue;' but we have also always referred to Burmeister's work above mentioned, which is the best guide to the ornithology of this district.

The number of skins submitted to our inspection is 265, referable to 96 species. Burmeister's list of the birds of the whole Argentine Republic includes 263 species.

Among the 96 species represented in the present collection the following 14 are not included in Burmeister's list :-

Geothlypis velata.

Molothrus rufo-axillaris.

Synallaxis maluroides.

anthoides.

Limnornis curvirostris.

Myiotheretes rufiventris.

Myiobius navius.
Picus mixtus.

Circus macropterus.

Columba picazuro.

Egialitis falklandica.

Tringa bonapartii.

$\longrightarrow$ bairdi.

Butorides cyanurus.

It is most important that this district should be thoroughly worked out, in order that the whole of Azara's species may be reidentified. We trust, therefore, that Mr. Hudson will continue his collections in this interesting locality, and that we may again have the pleasure of calling the Society's attention to this subject.

\section{Turdus leucomelas.}

Zorzal obscuro y blanco, Azara, A punt. i. p. 341.

Turdus leucomelas, Vieill. N. D. xx. p. 226, et E. M. 644.

Turdus crotopezus, Burm. La-Plata-Reise, ii. p. 474.

Turdus amaurochalinus, Cab. Mus. Hein. p. 568 ; Scl. et Salv. P. Z. S. 1866 , p. 177.

The receipt of this species from this locality, where it is stated to be "resident," appears to settle the question of its being Azara's "Zorzal obscuro y blanco." It therefore becomes entitled to bear the name leucomelas of Vieillot. We have compared Mr. Hudson's specimens with a typical example of $\boldsymbol{T}$. amaurochalinus, and find them identical.

This Thrush has a wide range in South America. Natterer collected examples at Ypanema in Brazil, one of which is now in the Bremen Museum. Sclater's collection contains specimens from other parts of Brazil, Bolivia, and Cayenne. Bartlett has recently sent specimens from the Ucayali, as we have already noted.

2. Turdus rufiventris (Vieill.); Burm. $l . c$. p. 474. 
3. Mimus calandria (Lafr. et d'Orb.); Burm. l. c. p. 475.

We are now convinced that Mimus modulator, Gould, is identical with this species. Sclater's Bolivian M. calandria (P. Z. S. 1859, p. 343) seems to differ principally in its smaller dimensions, and is perhaps hardly distinct.

4. Polioptila dumicola (Vieill.).

Culicivora dumicola, Burm. l. c. p. 473.

"Resident,"

5. Anthus correndera (Vieill.).

A. rufus, Burm. l.c.p. 474.

"Resident."

6. Geothlypis velata (Vieill.).

Two specimens of this species, agreeing with Brazilian skins. Not mentioned by Burmeister. "Summer visitor."

7. Progne tapera (Linn.).

Colyte tapera, Burm. l. c. p. 477.

H. fusca, Vieill. ex Azara, No. 301.

Phaoprogne fusca, Baird, Rev. A. B. p. 285.

Several examples of this species, agreeing with specimens so named in Sclater's collection. We do not know Baird's P. tapera as distinguished from his $P$. fusca.

8. Hirundo leucorrhoa (Vieill.).

Cotyle leucorrhoea, Burm.l.c. p. 478.

Several examples of this distinct species. $H$. albilinea of Lawrence is rightly associated by Baird (Rev. A. B. p. 297) with this species, but is readily distinguishable by its smaller size.

9. Thanagra cyanoptera (Vieill.)

T. sayaca, Burm. l. c. p. 479.

Six skins of this species, all marked females, and without the bright blue on the lesser wing-coverts.

10. Tanagra striata (Gm.); Burm. $l . c$. p. 480.

11. Guiraca glauco-cerelea (Lafr. et d'Orb.).

Coccoborus glaucocaruleus, Burm. l. c. p. 488.

Two male specimens only of this highly interesting species.

12. Zonotrichia pileata (Bodd.).

Z. matutina, Burm. l.c. p. 486 .

"Resident." 
13. Poospiza nigro-rufa (Lafr. et d'Orb.); Burm.l. c.p. 484. "Summer visitor."

14. Embernagra platensis (Gm.); Burm. l.c.p. 485.

15. Chrysomitris barbata (Mol.); Sclater, P. Z. S. 1867, p. $332=$ C. marginalis, Bp. et Burm. l. c. p. 490.

16. Sycalis arvensis (Kittl.); Sclater, P.Z. S. 1867, p. 323.

S. luteiventris, Burm. l.c. p. 489.

It is somewhat doubtful whether S. luteiventris is specifically identical with this species, which agrees with Chilian specimens. See Sclater's remarks, P. Z. S. 1867 , p. 342 .

17. ICterus pyrrhopterus (Vieill.).

Xanthornus pyrrhopterus, Burm. l.c. p. 493.

18. Molothrus bonariensis (Gm.); Cassin, Pr. Ac. Phil. 1866 , p. 19.

Molobrus sericeus, Burm. l.c. p. 494.

19. Molothrus rufoaxillaris, Cassin, Pr. Acad. Phil. 1866, p. 23.

Two specimens (both males) of this highly interesting species, which we have not met with before. It seems to have escaped Burmeister's notice.

20. Molothrus badius (Vieill.); Burm. l. c. p. 495.

Dolichonyx badius, Cassin, Proc. Acad. Phil. 1866, p. 15.

Sexes, as determined by Mr. Hudson, alike.

21. Pseudoleistes virescens (Vieill.).

Leistes anticus, Burm. l.c. p. 491.

A pair of this species, distinguishable from $P$. viridis by the want of the yellow rump. The female is scarcely different from the male, being only somewhat less bright in colouring.

22. Leistes superciliaris, Bp.

Trupialis guianensis, Burm. l.c. p. 490.

23. Geositta cunicularia (Vieill.); Burm. l.c.p. 465.

24. Furnarius rufus (Gm.); Burm. l. c. p. 462.

25. Cinclodes fuscus (Vieill.).

C. vulgaris, Burm. l.c. p. 463.

26. Synallaxis albescens, Kittl.; Burm. l.c.p. 469.

27. Synallaxis melanops (Vieill.); Burm. l.c. p. 470.

"Inhabits marshes." 
28. Synallaxis albescens (Temm.).

One skin, marked "very scarce," agreeing with South-Brazilian examples of this species. Burmeister's S. ruficapilla (l. c. p. 468) is probably the same bird; but the true S. ruficapilla (Vieill.) seems to be the Brazilian species with the whole head and tail rufous. See Sclater, P. Z. S. 1856 , p. 97 .

29. Synallaxis maluroides (D’Orb.).

Not noticed by Burmeister.

30. Synallaxis anthoides, King.

Not mentioned by Burmeister. " Resident : lives on the ground."

31. Anumbius acuticaudatus (Less.); Burm. l.c.p. 467.

32. Placellodomus ruber (Vieill.); Burm. l. c.p. 467.

33. Limnornis curvirostris, Gould, Zool. Voy. Beagle, iii. p. 81, t. 25 .

Two skins of this rare species originally obtained by Darwin from reed-beds in the vicinity of Maldonado. Not mentioned by Burmeister.

\section{Thamnophilus argentinus, Cab.; Burm.l. c. p. 472.}

"Summer visitor." Three skins of this species, representing the Brazilian Th. torquatus. The female has the tail rufous, and no cross bands on the body below.

35. Myiotheretes rufiventris (Vieill.).

Not mentioned by Burmeister, but obtained by Mr. Darwin at Maldonado and Bahia Blanca, and in Sclater's collection from the Parana.

36. Tenioptera coronata (Vieill.); Burm. l.c. p. 459.

37. Tenioptera irUPero (Vieill.).

T. moesta, Burm. l.c. p. 460.

38. Sisopygis ICTEROPHRYS (Vieill.).

Tanioptera icterophrys, Burm. l.c. p. 460.

"Summer risitor." Sexes, as marked, alike.

39. Lichenops perspicillatus (Gm.); Burm. l.c. p. 457.

Three specimens of this bird in black plumage, and two in the rufous plumage (L. erythropterus), which Mr. Darwin* considers to be a distinct species, but which is usually regarded as the same bird in female dress. Two of Mr. Hudson's black-plumaged birds are marked femules; but so are also both his red-plumaged ones,'so that we can offer no additional evidence upon this disputed point. We 
may remark that Azara (Apunt. ii. p. 250) described these two birds as sexes, although he had already described (l.c.p. 117) the female as a different species.

40. Machetornis rixosa (Vieill.); Burm. l.c. p. 458.

41. Centrites niger (Bodd.); Burm. l.c. p. 458.

4.2. Serpophaga subcristata (Vieill.); Burm. l.c.p. 454.

43. Serpophaga nigricans (Vieill.); Burm. l.c.p. 454.

44. Elainea modesta (Tsch.); Burm. l.c. p. 454.

Agrees with the Chilian birds. See Sclater's notes upon this species, P. Z. S. 1867 , p. 327.

45. Pitangus bellicosus (Vieill.).

Saurophagus sulphuratus, Burm. l.c. p. 452.

46. Myiobius nevius (Bodd.).

Not mentioned by Burmeister. Larger than, and possibly distinct from, the northern species (in which case it will, perhaps, stand as $M$. auriceps, Gould); but our series of specimens is not sufficient for comparison. "Summer visitor."

47. Pyrocephalus rubineus (Bodd.).

P.parvirostris, Gould; Burm. l.c.p. 456.

"Summer visitor."

After comparing a large series of skins of this form from many parts, we only feel satisfied as to the distinguishability of the northern $\boldsymbol{P}$. mexicanus, which seems always larger in size and paler in colour.

48. Tyrannus melancholicus (Vieill.); Burm. l.c.p. 452. "Summer visitor."

49. Milvulus violentus (Vieill.).

Tyrannus violentus, Burm. l.c. p. 453.

50. Podager nacunda, Vieill.; Burm. $l$. c. p. 449.

51. Stenopsis bifasciata, Gould; Sclater, P. Z. S. 1866, p. 140. Antrostomus longirostris, Burm. l.c. p. 450.

A single skin of an immature bird, probably referable to this species.

52. Guira pirtrigua (Vieill.).

Ptiloleptis guira, Burm. l. c. p. 443.

"Iris red." 
53. Picus mixtus, Bodd. (ex Pl. Enl. 748); Sundeval, Consp Pic. p. 20.

Not mentioned by Burmeister.

54. Chrysoptilus chlorozostus (Wagl.).

Chrysopicus chlorozostus, Malh.

P. chlorozostus, Sund. Consp. Pic. p. 75.

Chrysoptilus melanochlorus, Burm. l.c. p. 445.

Three specimens. "Frequents the woods on the shores of the Plata." Quite erroneously united by Burmeister with its Brazilian representative $C$. melanochlorus.

55. Milvago chimango (Vieill.).

M. pezoporus, Burm. l. c. p. 434.

"Resident."

56. Urubitinga unicincta (Temm.).

Asturina unicincta, Burm. l.c. p. 436.

"Eye hazel."

57. Hypotriorchis femoralis (Temm.); Burm. l. c. p. 437.

"Winter visitor."

58. Tinnunculus sparverius (Linn.); Burm. l. c. p. 437.

59. Circus cinereus (Vieill.); Burm. $l . c$. p. 439.

"Inhabits the Southern Pampas."

60. Circus macropterus (Vieill.); Azara, No. 31.

One adult specimen of this Harrier marked ${ }^{*}$, but apparently a female. "Eyes hazel." Not mentioned by Burmeister.

61. Otus brachyotus (Forst.); Burm. l.c. p. 439.

62. Pholeoptynx cunicularia (Mol.).

Noctua cunicularia, Burm. l.c p. 440.

63. Zenaida maculata (Vieill.); Burm. l.c. p. 497.

64. Columbula picui (Temm.); Burm. l.c. p. 496.

65. Columba picazuro (Temm.).

Picazuro, Azara, No. 317.

This species is quite distinct from $C$. gymnophthalma (Temm.) and C. maculosa (Temm.), with which it has been often confounded. C. gymnophthalma has the bill yellow, not black as in this species.

66. Nothura maculosa (Temm.); Burm. l.c. p. 499.

67. Thinocorus rumicivorus, Eschsch.; Burm. l.c. p. 501. 
68. Egialitis falk Landica (Lath.).

One specimen of this bird, which is not mentioned by Burmeister.

69. Vanellus Cayennensis (Gm.); Burm. $l$. $c$. p. 502.

70. Eudromias modesta (Licht.).

Vanellus modestus, Burm. l.c. p. 502.

Four skins of this Plover in winter dress, and one in process of change to summer plumage. " Chorlito di inverno : a winter visitor." -W. H. H.

71. Himantopus nigricollis (Vieill.); Burm. l.c.p. 503.

“Eye red : resident."-W. H. H.

72. Gambetta melanoleuca (Gm.); Burm. l.c.p. 503.

"Summer visitor. Becassina."-W. H. H.

73. Gambetta flavipes (Gm.) ; Burm. l.c.p. 503.

“Summer visitor." - W. H. H.

74. Tringa bonapartir, Schlegel; Baird, Rev. A. B. p. 472.

"Winter visitor."-W. H. H. Four skins of this species, which seems to be the "Chorlito pestorejo pardo" of Azara. If this be so, the prior names Tringa fuscicollis (Vieill.) and T. campestris (Licht.) will be applicable to it. Burmeister does not mention it in his 'LaPlata-Reise ;' but it may be the Tringa campestris of his 'Syst. Ueb.' iii. p. 74.

\section{Tringa bairdi.}

Actodromas bairdi, Coues, Pr. Ac. Phil. 1851, p. 194.

One skin of this species, which appears to be the "Chorlito lomo negro" of Azara ; if so, Mr. Coues's name will have to give way to Tringa melanota, Vieill. (Tringa dorsalis, Meyen).

76. Gallinago paraguie (Vieill.); Schlegel, Mus. des P.-B. Scolopaces, p. 11.

Scolopax frenata, Burm. l.c. p. 503.

Schlegel makes this species different from his Gallinago frenata. But we may point out that Scolopax paraguire, Vieillot, and S. frenata, Lichtenstein, are both based upon Azara's "Becasina prima" (No. 387); so that these names cannot be used for different species.

The only two Snipes we have yet met with from La Plata, Patagonia, and Chili are the present species and G. stricklandi.

77. Rhynchea semicollaris (Vieill.).

Rh. hilarii, Burm. l.c.p. 504; Azara, no. 405.

One specimen.

78. Aramides ypecaha (Vieill.).

Rallus ypecaha, Vieill. (ex Azara). 
Aramides gigas, Burm. l. c. p. 504 ; Schlegel, Mus. d. P.-B. Ralli, p. 14.

"Gallinetta: eye yellow." This is certainly Vieillot's Rallus ypecaha, founded on Azara's Ypecaha, and appears to be the species indicated by Schlegel as $A$. gigas. We have not yet met with the allied species, which he calls Aramides ypecaha.

79. Rallus rhytirhynchus, Vieill.; Scl. et Salv. P. Z. S. 1867 , p. 990.

Aramides rytirhynchus, Burm. l.c. p. 504.

“Burito : a summer bird ; very scarce."-W. H. H. Two skins of this species, which we take to be the Rallus rhytirhynchus of Vieillot, founded upon Azara's “ Ypecaha pardo." Upon comparing them with Chilian specimens of Rallus sanguinolentus and the Peruvian skin of the same species obtained by Whitely (see P.Z.S. 1867, p. 990) it seems necessary to unite them all under the same name. The Chilian bird is certainly larger and has a longer beak; but Whitely's Peruvian skin is scarcely larger than one of the La Plata birds.

80. Fulica armillata, Vieill.; Burm. l.. . p. 505.

One immature example, apparently, of this species. "Gallareta : eye hazel ; very common."-W. H. H.

81. Parra Jacana, Linn.; Burm. l. c. p. 506.

Two examples of this wide-ranging species.

82. Chauna chavakia (Linn.); Burm. l.c.p. 506.

"Chaja."-W. H. H.

83. Butorides cyanurus (Vieill.). Azara).

Ardea cyanura, Vieill. N. D. xiv. p. 21, et E. M. p. 1120 (ex B. scapularis, Bp. Consp. ii. p. 128.

"Summer visitor." Apparently not mentioned by Burmeister.

84. Ibis Falcinellus, Linn.

T. chalcoptera, Burm. l.c. p. 511 .

"Summer visitor." Cf. Schlegel, Mus. d. P.-B. Ibides, p. 4, et v. Pelz. Novara-Reise, p. 125.

85. Platalea ajaja (Linn.); Burm. l.c. p. 511.

86. Phennicopterus ignipalliatus, Is. Geoffr.; Burm. $l$. $c$. p. 512 .

87. Cygnus nigricollis (Gm.); Burm. l.c.p. 512.

88. Spatula platalea (Vieill.); Burm. l.c. p. 517.

Proc. Zool. Soc.-1868, No. X. 
89. Querquedula flavirostris (Vieill.); Burm. l. . p. 516.

Concerning the distinctness of this species from $Q$, oxyptera we have already spoken (P. Z. S. 1867, p. 990).

90. Querquedula versicolor (Vieill.).

A. maculirostris, Burm. l.c. p. 516.

91. Dafila bahamensis (Linn.); Burm. l.c. p. 515.

92. Dafila spinicauda (Vieill.); Burm. l.c. p. 515.

93. Metopiana peposaca (Vieill.); Burm. l. c. p. 518.

This Duck is not a Fuligula, as Burmeister has already shown. Nor can it be placed with Anas, as it has a large bulbous expansion in the windpipe, besides the curious bulging forehead. We have therefore adopted for it a generic name invented by the late Prince Bonaparte (C. R. xliii. p. 649).

94. Larus cirrhocephalus (Vieill.) (ex Azara, No. 410).

L. maculipennis, Burm.l.c. p. 518.

One skin in winter dress.

95. Podiceps rollandi, Q. et G.

A single young specimen. Not mentioned by Burmeister, unless it be the $\boldsymbol{P}$. bicornis, Licht., which we are not at present able to ascertain with certainty.

96. Phalacrocorax brasilianus (Licht.); Burm.l. c. p. 520.

7. Notice of Clymene similis, a New Dolphin sent from the Cape by Mr. Layard. By Dr. J. E. GraY, F.R.S., V.P.Z.S., F.L.S., \&c.

Mr. Edgar Layard has sent from the Cape the skull of a Dolphin with the under jaw, which is so like the skull I figured under the name of Delphinus obscurus in the 'Zoology of the Erebus and Terror,' t. 16, that I at first regarded it as the same. But having occasion to recompare it to identify the skull of a very young Dolphin that Mr. Layard has since sent from the Cape, I was interested in finding that it showed the same kind of difference in the form of the hinder part of the palate in front of the internal nostrils that I have before observed in some true Dolphins which had very similar skulls in other respects, but which belong to Dolphins very differently coloured, which were obtained in distinct parts of the world.

In this case the two skulls both come from animals found at the Cape; but several Dolphins inhabit the seas surrounding that promontory.

I have thought it desirable to distinguish the two skulls by dif- 


\section{$2 \mathrm{BHL}$ Biodiversity Heritage Library}

Gould, John. 1868. "February 13, 1868." Proceedings of the Zoological Society of London 1868, 71-156. https://doi.org/10.1111/j.1469-7998.1868.tb00444.x.

View This Item Online: https://www.biodiversitylibrary.org/item/91104

DOI: https://doi.org/10.1111/j.1469-7998.1868.tb00444.x

Permalink: https://www.biodiversitylibrary.org/partpdf/73844

\section{Holding Institution}

Natural History Museum Library, London

\section{Sponsored by}

Natural History Museum Library, London

\section{Copyright \& Reuse}

Copyright Status: Public domain. The BHL considers that this work is no longer under copyright protection.

This document was created from content at the Biodiversity Heritage Library, the world's largest open access digital library for biodiversity literature and archives. Visit BHL at https://www.biodiversitylibrary.org. 